\title{
Rewriting Mansfield: Writing, Editing and Translation
}

\author{
By \\ Davide Manenti
}

A thesis submitted to the Victoria University of Wellington in fulfilment of the requirements for the degree of

Doctor of Philosophy in

Literary Translation Studies

Victoria University of Wellington 


\begin{abstract}
This thesis explores the notion, the process and the ethical implications of rewriting, drawing on insights from literary and translation theories, psychoanalysis and trauma studies. It analyses three major forms of rewriting: the author's, the editor's and the translator's. While writing, editing and translation have their own specific norms of production, methodologies, possibilities and limits, all these textual practices are implicitly concerned with the meaning-making process of rewriting.

Chapter One presents the central case study of the project: John Middleton Murry's editing of Katherine Mansfield's notebooks, which resulted in the publication of Journal of Katherine Mansfield (1927). The chapter reviews relevant Mansfield scholarship and discusses textual, methodological and theoretical issues concerning the problem of rewriting. Chapter Two follows the ebb and flow of Mansfield's own rewriting process by discussing the ways in which she 'translated' her notebook entries into her fiction. Chapter Three offers a re-reading of the Journal of Katherine Mansfield and sheds new light on Murry's controversial editorial manipulation. Chapter Four examines the first Italian translation of the Journal - Diario di Katherine Mansfield, authored by Mara Fabietti in 1933 - and my own re-translation of 'Life of Ma Parker' - a 1921 Mansfield story that epitomizes the main themes and issues addressed in this study.
\end{abstract}


This thesis demonstrates how deeply intertwined writing, editing and translating are, and presents an understanding of rewriting as a complex and fascinating process that simultaneously resists meaning and yearns for it. 
To the memory of my mother

To my father

We die. That may be the meaning of life.

But we do language. That may be the measure of our lives.

TONi MORRISON, 'Nobel Lecture'

Did it matter then, she asked herself, walking towards Bond Street, did it matter that she must inevitably cease completely; all this must go on without her; did she resent it; or did it not become consoling to believe that death ended absolutely? but that somehow in the streets of London, on the ebb and flow of things, here, there, she survived. Peter survived, lived in each other, she being part, she was positive, of the trees at home; of the house there, ugly, rambling all to bits and pieces as it was; part of people she had never met; being laid out like a mist between the people she knew best, who lifted her on their branches as she had seen the trees lift the mist, but it spread ever so far, her life, herself.

Virginia Woolf, Mrs Dalloway 


\section{Contents}

vi Acknowledgments

1 Introduction

5 CHAPTER ONE

The 1927 Journal:

Critical and Theoretical Issues

27 CHAPTER TWO

'Until I simply exhaust my store':

Writing, Rewriting and Working-through

60 CHAPTER THREE

After the End:

Editing Mansfield

97 CHAPTER FOUR

Translating Mansfield

135 Conclusions

140 Works Cited 


\section{Acknowledgments}

I want to thank my supervisor, Dr Marco Sonzogni, who supported this project from the very beginning. His enthusiasm and advice have greately benefited my work. I am also grateful to my secondary supervisor, Dr Sally Hill, for her edits and insightful suggestions every step of the way.

I am indebted to Victoria University of Wellington for funding my doctoral assistantship. The School of Languages and Cultures has provided a friendly and supportive work environment; a special word of thanks goes to the School administrator, Nina Cuccurullo.

In 2007, when I was studying for my master's degree in Book Publishing at the University of Milan, I had the good fortune to attend Franca Cavagnoli's lectures. She revealed to me the fascinating and endlessly challenging art of translation and opened the gate to the path that led me here. Without her, I would not even have dared to embark upon this New Zealand journey.

A number of friends and colleagues have read and offered their helpful comments on my writing; in particular, I want to thank Keren Chiaroni, Bob Lowe, Paul Frisby and Kirsten Reid. I would also like to express my gratitude to Giulio Chimetto, 
Massimiliano Matteri, Mirko Lamonaca, Maria Letizia Tonelli, and Naomi Trigg for their love and friendship.

Finally, I want to thank my family: my aunts and uncles, my brothers Francesco and Andrea, my grandmother Giuseppina and Pietro, my father. My greatest thank goes to my mother Mina, with whom I spent many hours talking about this research project. She was a gentle, loving, admirable woman - and a mother to the end. 


\section{Introduction}

The initial idea for this project was a comparative study of the Italian translations of Katherine Mansfield's works. I was particularly interested in her Journal, which was published posthumously in 1923 by her husband, John Middleton Murry, and translated into Italian a few years later. As soon as I became familiar with the Journal's publishing history, however, I realized that the Italian translation was only the top layer of a much deeper palimpsest. The Journal of Katherine Mansfield - the supposed 'source text' - was a highly selective and manipulated version of Mansfield's manuscripts - a series of notebooks, diaries and papers that she never intended for publication. Moreover, the author herself often reused her notebook material as a stepping-stone towards her fiction. I found myself in the middle of a terrain vague: the unexplored but fascinating domain of rewriting.

This thesis has a twofold purpose: to shed new light on the multiple 'afterlives' of Mansfield's notebooks while exploring a number of key theoretical issues about the notion of rewriting itself. 
In Chapter One, I review relevant scholarship on Murry's editing, arguing that the different and conflicting assessments of the editor's task can be explained, first of all, from a textual point of view. Murry produced two editions of the Journal: one in 1927 and the other in 1954. In the first edition, he intervened in Mansfield's text several times, particularly in her most personal diary entries. The 1954 'definitive' edition, albeit still selective, reproduced a much larger portion of the manuscripts; the editor also corrected, as much as he could, his previously censured transcriptions. A distinction of these two versions is therefore essential for a critical appreciation of Murry's editing process. For reasons that I will explain in due course, I am here exclusively concerned with the first edition of the Journal.

In the opening chapter I also review two influential studies on rewriting: Gérard Genette's Palimpsests: Literature in the Second Degree and André Lefevere's Translation, Rewriting and the Manipulation of Literary Fame. Genette's investigation on the palimpsestic nature of literature is still useful, especially from the point of view of textual analysis. However, Genette focused mostly on the 'sunnier side' of rewriting - that is, on texts whose rewriting is openly stated - thus avoiding any discussion on the ideological constraints that govern literary rewritings. Rather different was Lefevere's approach, which showed in an unmistakable way that practices of rewriting are culturally, ideologically and personally determined. And yet the notion of rewriting offered by Lefevere - a practice occurring 'in the middle', between writing and reading - is still not entirely persuasive. My argument is that rewriting is best 
understood as a process that transcends conventional boundaries between different practices.

In Chapter Two I investigate the ways in which Mansfield 'translated' some of her notebook entries into her short stories. 'An Indiscreet Journey', 'The Woman at the Store' and 'The Garden Party', however, are not only the result of an actual practice of rewriting but also exemplify - in their rhetoric and themes - some key issues at the heart of rewriting itself. More specifically, these stories problematize the complex relationship between reference and representation - the what and the how of literary rewriting. My research intersects here with trauma theory: the notion of trauma - an event, according to Cathy Caruth, which simultaneously claims and challenges our understanding - can be purposefully employed for a better appreciation of Mansfield's rewriting process and of rewriting in general. My close readings - and in particular my analysis of 'The Woman at the Store' - also provide new insights into the field of Mansfield studies, examining a number of texts that have received little critical attention so far.

In Chapter Three I explore Murry's editing process resulting in the 1927 Journal of Katherine Mansfield. I begin by addressing the vexed question of the Journal's authorship. Murry adhered to a romantic conception of authorship that contributed to the 'invisibility' of his editorial intervention and to the consequent foregrounding of the diarist's 'true presence'. My analysis draws on Lawrence Venuti's theory of the translator's invisibility and on Giorgio Agamben's notion of 'state of exception'. I then provide a number of significant examples of editorial 'trimming', indentifying 
the 'implied author' created by Murry. This, in turn, allows me to describe the editing process in terms of a fictional plot. In the closing section of the chapter I suggest that the narrative tension between the fragment and the whole underlying Murry's editing process bears witness to Mansfield's own desire to overcome the sense of fragmentation that she experienced as a woman and as a writer; a sense of fragmentation that, I argue, has its origin in her traumatic encounter with death.

In Chapter Four I focus on the rewriting process enacted in translation. The problematic relationship between reference and representation is particularly evident in the movement from one language to another. First and foremost, I ask whether and how can translation be considered as a form of 'testimony'. Combining Trauma Studies with Translation Studies - and adopting, in particular, Antoine Berman's translation ethics - I put forward a rethinking of translation as a form of testimony that originates where a direct access to meaning seems to be denied. Following this theoretical framework, I undertake a close reading of Mara Fabietti's 1933 translation of the Journal and my new translation of Mansfield's 1920 story, 'Life of Ma Parker'. This story and the translational issues it raises epitomize central aesthetic and ethical questions addressed in this study, highlighting once again the paradoxical nature of rewriting as both loss and gain, violence and gift, destruction and survival. 


\title{
Chapter One
}

\section{The 1927 Journal:}

\section{Critical and Theoretical Issues}

\begin{abstract}
La cognizione del vero non è altro che lo spogliarsi degli errori, e sapientissimo è quello che sa vedere le cose che gli stanno davanti agli occhi, senza prestar loro le qualità ch'esse non hanno.
\end{abstract}

GIACOMO LEOPARDI

In February 1923, some weeks after Katherine Mansfield's funeral, John Middleton Murry wrote a letter to her literary agent J.B. Pinker. The letter displays an ambitious editorial plan concerning Mansfield's published and unpublished works. Murry also made arrangements for a book provisionally entitled 'Journal \& Sketches', 'containing some of her finest \& most individual works' ${ }^{1}$ and scheduled to come out in 1924. However, this timeframe turned out to be optimistic. 'Excerpts from a Journal' appeared in two issues of the Yale Review (1923) and regularly in The Adelphi for a couple of years, but the first edition of the Journal of Katherine Mansfield - this was the title eventually chosen - would come out only in 1927.

\footnotetext{
${ }^{1}$ John Middleton Murry to J.B. Pinker, 1 February 1923, MS-Papers-3981-106, Alexander Turnbull Library, Wellington.
} 
Published by Constable, London, the book - an elegant small crown octavo, printed in a bluish-grey hardcover with violet rules - met with instant success. In the wake of this, Murry embarked on the publication of almost everything Mansfield had left behind: among other works, the Scrapbook of Katherine Mansfield (1937) and the 'definitive edition' of the Journal of Katherine Mansfield (1954). The former presented more notebook-like fragments of Mansfield's manuscripts; the latter was a revised edition of the 1927 Journal containing - according to the editor - some passages previously included in the Scrapbook and more unpublished material. Three years after this last editorial work John Middleton Murry died.

At this point a large part of Mansfield's papers were auctioned at Sotheby's and purchased by the Turnbull Library of Wellington. ${ }^{2}$ Soon after, Ian Gordon, professor of English at Victoria University of Wellington, conducted a survey of the collection. He was astonished to discover that the Murry editions were all culled from the same manuscript source: an omnium-gatherum of loose papers, notebooks and unfinished diaries. In his introductions to each edition, Murry was rather elusive on the nature of the source material and on the editorial method he adopted. After a cursory collation of the manuscripts with their published versions, Gordon declared the Journal of Katherine Mansfield to be 'a brilliant piece of literary synthesis and editorial

\footnotetext{
${ }^{2}$ For a detailed account of the manuscripts' acquisition, see Ian Gordon, 'Katherine Mansfield in the Late Twentieth Century', in The Fine Instrument, ed. by Paulette Michel and Michel Dupuis (Sydney: Dangaroo Press, 1989), pp. 23-24.
} 
patchwork'. ${ }^{3}$ The role that Murry played in collecting and arranging Mansfield's material furnished evidence for a dual authorship:

The combination of the remains of a writer of the calibre of Katherine Mansfield and an editor of the calibre of Murry produced what he was later - justifiably - to describe as a minor classic, which ran through many printings. It is hardly too much to claim that it is as much Murry's work as Katherine Mansfield's, though his only acknowledged part in the 1927 edition was the introduction and the 'minimum necessary words of explanation'. ${ }^{4}$

Gordon's assessment seemed to match the bad reputation that Murry garnered during his lifetime. A fascinating, complex and somehow disturbing personality, Mansfield's husband often lent himself to vicious judgements. His contemporaries reacted with outrage to what they saw as the reckless publication of his wife's remnants. Rayner Happenstall called him 'the best-hated man of letters's of his time. Sylvia Lynd accused him of 'boiling Katherine's bones to make soup'. ${ }^{6}$ Virginia Woolf asked in her diaries whether 'Katherine did something to deserve this cheap, posthumous life'. ${ }^{7}$ Leonard Woolf was similarly appalled, maintaining that Murry 'corrupted and perverted and destroyed Katherine both as a person and a writer'.

${ }^{3}$ Ian Gordon, 'The Editing of Katherine Mansfield's Journal and Scrapbook', Landfall, 13, no. 1, (1959), p. 64.

${ }^{4}$ Ian Gordon, 'The Editing of Katherine Mansfield's Journal and Scrapbook', p. 64.

${ }^{5}$ Quoted in F.A. Lea, The Life of John Middleton Murry (London: Methuen, 1959), p. 213.

${ }^{6}$ Quoted in Claire Tomalin, Katherine Mansfield: A Secret Life (London: Viking, 1987), p. 241.

${ }^{7}$ Virginia Woolf, The Diary of Virginia Woolf, ed. by Anne Olivier Bell, 5 vols (London: Hogarth Press, 1977), II, p. 238.

${ }^{8}$ Leonard Woolf, The Autobiography of Leonard Woolf (London: Hogarth Press, 1964), p. 204. 
When Murry died, in 1957, an obituary in the New York Times depicted him as 'a small man [who] had a dark view of life and a talent for inspiring hostility'.

Recent scholarship has significantly nuanced this negative view. Sydney Janet Kaplan's Circulating Genius: John Middleton Murry, Katherine Mansfield and D.H. Lawrence, while not seeking to revise Murry's reputation or make him 'fashionable', shed new light on his editorial and critical activity; he certainly was a 'circulator' of ideas, a key and neglected figure in the development of English literary modernism. ${ }^{10}$ A more balanced picture of Mansfield's husband was also provided by those biographers who have worked on Murry's unpublished diaries held at the Turnbull Library of Wellington. One example is Kathleen Jones' 2010 Mansfield biography. ${ }^{11}$ However, whether condemned for sanitizing the human and artistic portrait of Mansfield, or praised for his editorial flair, the editor of the Journal has continued to elude a persuasive assessment.

\section{Textual fallacies and blind readings}

As Ian Gordon pointed out in his pivotal article, Mansfield did not keep a journal uninterruptedly throughout her life: the published versions of her notebooks were the result of a selection and arrangement of her entries out of a confusing pile of unfinished diaries, notebooks and loose sheets of paper. A significant amount of

\footnotetext{
${ }^{9}$ The New York Times, 15 March 1957, p. 29.

${ }^{10}$ Sydney Janet Kaplan, Circulating Genius: John Middleton Murry, Katherine Mansfield and D.H. Lawrence (Edinburgh: Edinburgh University Press, 2010).

${ }^{11}$ Kathleen Jones, Katherine Mansfield: The Storyteller (London: Penguin, 2010).
} 
Mansfield scholarship has addressed this specific question: To what extent, if any, did Murry's selection and arrangement of Mansfield's jottings impact on the reception of her as a woman and as a writer?

'What is important - and misleading to a biographer - is that many passages of apparently continuous writing are not really continuous at all. These have been assembled from different sources', ${ }^{12}$ Gordon argued. According to Ruth Mantz, the editorial shuffling of Mansfield's jottings eventually produced a piece of documentation that 'might as well be classified as fiction'. ${ }^{33}$ Similarly, in his 1974 article on the Journal, Philip Waldron argued that the distortion of the text in turn distorted the personality of the writer herself' fuelling the myth 'of a temperamentally ethereal figure'. ${ }^{14}$ According to these readings, the literary myth of Katherine Mansfield stemmed from an editorial activity whose strategies recall those of a narrator rather than of an editor. As Gillian Boddy put it, 'while Mansfield may have described herself to her former editor Orage as "a selective camera", this was probably an even truer description of Murry. [...] He too was an artist in his way and one with a particular image to protect'. ${ }^{15}$

\footnotetext{
${ }^{12}$ Ian Gordon, 'The Editing of Katherine Mansfield's Journal and Scrapbook', p. 67.

${ }^{13}$ Ruth Mantz, 'Katherine Mansfield: Fifty Years After', Adam (1972), p. 127.

${ }^{14}$ Philip Waldron, 'Katherine Mansfield's Journal', Twentieth Century Literature, 20, No. 1 (1974), p. 18.

${ }^{15}$ Gillian Boddy, 'Leaving “All Fair”? Working Towards a New Edition of Katherine Mansfield's Notebooks', in Worlds of Katherine Mansfield, ed. by Harry Ricketts (Palmerston North: Nagarre Press, 1991), p. 13.
} 
Nevertheless, not all critics have supported this view. C.K. Stead, for example, in the preface of Letters and Journals of Katherine Mansfield, challenged Gordon's claim, arguing that 'another disposition of the same material [...] would have hung together quite as well, and this is because of the essential unity of Katherine Mansfield's writing in letters and notebooks. [...] Murry had only to transcribe more or less at random to achieve a book coherent enough to become a "minor classic". ${ }^{16}$ Even more sympathetic was the description of Murry's editorial method offered by Margaret Scott in the introduction to The Katherine Mansfield Notebooks, the first unabridged edition of Mansfield's papers:

One can barely imagine what it must have been like for him to find himself suddenly in possession of this vast mass of material. Not only was it scarcely legible, it was full of judgements on him and complaints about him - sudden stinging bites, some of them poisonous. It must have been agonizing for him to keep coming across KM's bitter accusations and misunderstandings. No matter how much he told himself her warped view of him was due to her illness, the pain of all these discoveries must have been intense. Yet his courage never failed him. He struggled on with the deciphering and whatever he did manage to read he published, without defensive explanations. Almost his only deliberate suppressions were names of people still alive at the time of publication. This courage and honesty [...] served only to harden the public perception of KM as the suffering and dying genius, and Murry as the cold, careless, inadequate husband. ${ }^{17}$

\footnotetext{
${ }^{16}$ Katherine Mansfield, Letters and Journals of Katherine Mansfield: A Selection, ed. by C.K. Stead (London: Penguin, 1977), p. 14.

17 Katherine Mansfield, The Katherine Mansfield Notebooks, ed. by Margaret Scott, 2 vols (Canterbury NZ: Lincoln University Press and Daphne Brasell Associates, 1997), I, p. XVII. Further references are cited parenthetically as KMN1 (Vol. 1) and KMN2 (Vol. 2) with the page number.
} 
Arguing that 'whatever he did manage to read he published, without defensive explanations' or significant suppressions, Scott sought to remove Murry from the role of the 'villain' assigned to him by generations of readers.

An original understanding of Murry's editing was recently offered by Anna Jackson. The diary form, she argued, is the result of two paradoxical forces, the 'autonomy of the entry and the sequencing of the structure';18 while Mansfield provided the first requirement of the periodic entry, Murry provided the second, by placing Mansfield's entries into a particular sequence. Nonetheless, Jackson seems to me to be undecided about the importance of editorial sequencing: on the one hand, from a theoretical point of view, she endows sequencing with a 'potential of creative narrative'; ${ }^{19}$ on the other hand, she argues that 'Murry's contribution remains editorial', downplaying once again the shaping force of his intervention: 'While the Journal is a work of dual authorship in the sense that Murry provided one of the two essential requirements of the genre, his calibre as an editor did not need to match Mansfield's calibre as a writer, as Gordon suggests, in order for the Journal to have become established as a minor classic' ${ }^{20}$

How could such conflicting, even opposite evaluations be possible? Did Murry’s editing contribute to the development of Mansfield's literary fame or not? And, if it

\footnotetext{
${ }^{18}$ Anna Jackson, Diary Poetics: Form and Style in Writers' Diaries (New York: Routledge, 2010), p.

${ }^{19}$ Anna Jackson, Diary Poetics, p. 71.

${ }^{20}$ Anna Jackson, Diary Poetics, pp. 91-92.
} 17. 
did, how and to what extent? Is it possible to trace, to a certain degree of accuracy and objectivity, his editorial footsteps?

Mansfield scholars have paid insufficient attention to the fact that Murry produced not one, but two editions of Journal of Katherine Mansfield: one that came out in 1927 and the other - almost thirty years later - in 1954. The most outstanding difference between the two is that the 1927 Journal is not simply a much more selective edition of Mansfield's papers, but also a manipulated version of them; a kind of manipulation that cannot be limited - as scholars have often suggested - to its selectiveness or to a simple and misleading arrangement of material. Indeed, in preparing the 1927 edition, Murry intervened in Mansfield's text several times, particularly in her most personal and compromising diary entries. He did so, it seems, to protect the reputation of people still alive (including himself) and to present a refined portrait of his wife. In the following pages, I will point to other reasons motivating Murry's editing process; what I want to pin down here, from a methodological point of view, is the importance of distinguishing between two very different editorial products.

Let us consider Gordon's article again. Although he gives a brief survey of all the editions that Murry produced from the same source of notebooks and papers, he exclusively centres his close reading on the 1954 text, focusing on some of Murry's deceptive choices in terms of disposition. However, the examples of editorial manipulation based on the 1954 version are not as significant as the many and different interventions undermining the 1927 text. Gordon's conclusion - 'The 
Journals present a complete and graceful persona of a writer, true in the essentials, but over rarefied ${ }^{21}$ - can certainly apply to the 1927 Journal, much less to the 1954 edition. Indeed Gordon speaks of 'Journals' - a plural expression encapsulating both versions. The problem is that, in doing so, he gives the impression that there was no substantial difference - in terms of textual manipulation - between the two volumes.

It is not surprising, then, that subsequent scholarship has focused almost exclusively on the 1954 'definitive' edition. We have seen that Stead questioned the dual authorship of the Journal by downplaying the shaping power of Murry's editorial arrangement. However, the arrangement of material scarcely accounts for Murry's sleight of hand in editing the 1927 Journal. Had Stead looked carefully at the first edition, he would have certainly come to a different conclusion. The same applies to the assessment of Murry's editorial method given by Margaret Scott, who compared her transcription solely to Murry's 1954 edition.

Textual matters impinge upon interpretation and turning a blind eye to them may undermine historical evaluation. A telling example is provided by Jeffrey Meyers, the author of the controversial biography Katherine Mansfield: A Darker View. In a 1979 article he showed how Murry's criticism and editorial work brought about an idealized portrait of Mansfield. However, as far as the Journal of Katherine Mansfield was concerned, his view was considerably different:

\footnotetext{
${ }^{21}$ Ian Gordon, 'The Editing of Katherine Mansfield's Journal and Scrapbook', p. 69.
} 
Though Murry was undoubtedly inaccurate, he nevertheless did brilliant and vital work as the editor of her Journal (but not of her other works). He frankly published Katherine's condemnations of his own behaviour, and did not attempt to defend himself against accusations which were sometimes inspired by her illness and depression. After examining the manuscripts myself, I found that he did not try to conceal intimate or unpleasant matters (the entries about Francis Carco are exactly the same as the published ones), and usually omitted what he could not decipher, what was trivial, and what was libellous. ${ }^{22}$

This assessment could only be based on the 1954 Journal - but Meyers did not point this out. As a matter of fact, in the first edition Murry painstakingly and severely edited personal entries like those concerning Mansfield's relationship with Francis Carco.

The significance of the 1927 edition is still to be recognized and assessed. For almost thirty years, this was the only available version of Mansfield's Journal - the version that contributed to the growth of Mansfield's literary legend. But its influence went even further, as the same version was republished again and again over the following decades, despite the competing presence of more or less 'definitive' versions. And it is not by chance that two recent reprints of the Journal of Katherine Mansfield, in English and in Italian translation, present once again the 1927 version. $^{23}$ Why has this edition been so popular? What made it special among all others? Why

\footnotetext{
${ }^{22}$ Jeffrey Meyers, 'Murry's Cult of Mansfield', Journal of Modern Literature, Vol. 7, No. 1 (1979), p. 36.

${ }^{23}$ The English reprint was published by Persephone Books in 2006; Mara Fabietti's 1933 Italian translation of the Journal was reprinted by Robin Editore in 2002.
} 
were publishers and readers more attracted to this version than to more dependable ones?

The answer to these questions lies in the process of the rewriting of Mansfield's notebooks. Before embarking on this analysis, however, a preliminary discussion of the concept of rewriting itself is necessary. I will now examine two important and influential contributions on rewriting: Gérard Genette's Palimpsests: Literature in the Second Degree and André Lefevere's Translation, Rewriting and the Manipulation of Literary Fame. After describing the strengths and weaknesses of these works, I will outline the approach I am going to take in my thesis.

\section{Genette's taxonomy and beyond}

Gérard Genette's 1982 monograph, Palimpsests: Literature in the Second Degree, is still the most comprehensive and systematic investigation of hypertextuality, that is, the relationship uniting a text $\mathrm{B}$ (the hypertext) to a text $\mathrm{A}$ (the hypotext), 'upon which it is grafted in a manner that is not that of commentary'. ${ }^{24}$ Hypertextuality is one of the five forms of what Genette calls transtextuality ('all that sets the text in a relationship, whether obvious or concealed, with other texts', 1). ${ }^{25}$ Although Genette

\footnotetext{
${ }^{24}$ Gérard Genette, Palimpsests: Literature in the Second Degree, trans. by Channa Newman and Claude Doubinsky (Lincoln: University of Nebraska Press, 1997), p. 5. Subsequent page references are included parenthetically in the text.

${ }^{25}$ Transtextuality also includes: paratextuality (the relationship between the text and the paratext: titles, subtitles, prefaces, book covers, epigraphs, etc.); intertextuality (the relationship of two text by means of quotation, plagiarism and allusion); metatextuality (the relationship of a text commenting upon another text); and architextuality (the relationship that binds the text with its genre classification).
} 
does not normally use the word rewriting, hypertextual relationships are based, quite obviously, on processes of rewriting.

Particularly useful for our purpose are the examples of what Genette calls 'quantitative transformation' by reduction (228), that is to say: excision ('suppression pure and simple'), concision (the rewriting of a text 'in more concise style') and condensation (which depends 'only in an indirect way upon the text to be reduced' and is exemplified by the common practice of summary). Excision - the kind of reduction that better applies to Murry's editing - can be obtained by means of amputation or trimming. The first consists of a 'single massive excision' (229) and represents 'very widespread literary, or at least editorial, practice' (229); it is exemplified, for instance, by the 'many editions for children of Robinson Crusoe that reduce this chronicle to the only part that is truly "Robinsonian" in the modern sense of the word' (230). The case of trimming - consisting of 'multiple excisions disseminated throughout the text' (230) - is even more frequent than amputation. Again, Genette offers the example of abridged adventure novels, where tedious narrative sections are trimmed ad usum Delphini. Genette also uses the term expurgation - obtained through amputation or trimming - to identify 'reduction with a moralizing or an edifying function' (235). 'Censorship', Genette continues, 'is obviously the adult version of this same practice' (235). Some of the passages omitted by Murry in the published version of the Journal undoubtedly fall under this category.

Although Genette's taxonomy is useful for textual analysis - I will employ it myself - his theoretical framework presents some difficulties. One of these has to do 
with the notion of 'transformation' as a 'purely quantitative' operation. At the beginning of his work Genette argues that ' $[\mathrm{i}] \mathrm{n}$ order to transform a text a simple and mechanical gesture might suffice (an extreme example would consist in tearing off a few pages - a case of reductive transformation', 6). Later on, when he deals with transposition (a type of transformation which includes translation), he argues that there are two categories of it:

Transpositions that are in principle (and in intention) purely formal, which affect meaning only by accident or by a perverse and unintended consequence, as in the self-evident case of translation (which is a linguistic transposition); and transpositions that are overtly and deliberately thematic, in which transformation of meaning is manifestly, indeed officially, part of the purpose. (214)

This distinction is to me not entirely persuasive. First, because it re-establishes the old cleavage between form and content against which formalist critics (among others) had warned us a long time ago. ${ }^{26}$ Second, the consideration of translation as a purely linguistic transposition, which affects meaning 'only by accident', is based on a principle of equivalence between languages that is no longer accepted in contemporary Translation Studies. Translator theorists would certainly contest Genette's definition of translation as merely 'linguistic transposition'. 'Translation', as

\footnotetext{
26 ' [I]n a successful work, form and content cannot be separated. [...] form is meaning', Cleanth Brooks, 'My Credo: The Formalist Critics', Kenyon Review, XIII (1951), p. 72.
} 
Susan Bassnett puts it, 'involves far more than replacement of lexical and grammatical items between languages.' 27

Despite his theoretical assumptions, Genette knows that the question of meaning is always at stake in any process of transformation. When he deals with the problem of 'quantitative transformations', for instance, he concedes that 'a text [...] can be neither reduced nor enlarged without undergoing other changes more essential to its inherent textuality' (228). To transform a text means to introduce 'changes that quite evidently affect not only length but also structure and substance. To reduce or augment a text is to produce another text, briefer or longer, which derives from it, but not without altering it' (229). Again, in his analysis of amputation, Genette argues that 'this practice of rewriting is built upon (and in its turn reinforces) a practice of reading' (230), and ' $\mathrm{t}$ ] $\mathrm{o}$ read means to choose, for better or for worse, and to choose means to leave out' (239).

These remarks are at odds with a view of transformation as 'mechanichal gesture' or 'purely quantitative' operation, and raise a number of complex questions. What are the motives behind reading, choosing, leaving out - rewriting? What kind of relationship exists between what is left out and what is included, between what is trimmed away and what is not? Is it really possible to fully describe the palimpsestic

\footnotetext{
${ }^{27}$ Susan Bassnett, Translation Studies (New York: Routledge, 2002), p. 34. See also: Susan Bassnett, 'The Translation Turn in Cultural Studies', in Constructing Culture: Essays on Literary Translation, ed. by Susan Bassnett and André Lefevere (Clevedon: Multilingual Matters), pp. 123-140; Itamar EvenZohar, 'The Position of Translated Literature Within the Literary Polysystem', in Literature and Translation, ed. by James Holmes, Jose Lambert and Raymond van den Broek (Leuven: ACCO, 1978), pp. 117-127; André Lefevere, 'Translation Studies: The Goal of the Discipline', in Literature and Translation; Rethinking Translation: Discourse, Subjectivity, Ideology, ed. by Lawrence Venuti (London: Routledge, 1992).
} 
nature of rewriting without taking into account its pragmatic, extra-literary dimension? What links the invisible choices of the rewriter to interpretation and reception?

Genette is reluctant to address these questions directly. As he declares at the outset of his work, he prefers to deal with 'the sunnier side of hypertextuality: that in which the shift from hypotext is both massive (an entire work B deriving from an entire work A) and more or less officially stated' (9). And when his neat investigation inevitably runs into 'less official' rewriting practices (censorship, for instance), these are only cursorily examined, leaving more questions than answers.

\section{Lefevere's notion of rewriting: some answers, more questions}

A deeper investigation into the 'dark side' of rewriting was offered by André Lefevere. Lefevere was associated with the so-called Manipulation School, a group of scholars that played a key role in the 'cultural turn' of Translation Studies. ${ }^{28}$ Lefevere's work on rewriting can be traced in a number of contributions; worthy of mention is his 1981 article 'Translated Literature: Towards an Integrated Theory', where Lefevere introduces the concept of 'refracted texts', that is, 'texts that have been processed for a certain audience (children, for example), or adapted to a certain poetics or a certain ideology'. ${ }^{29}$ Lefevere came back to this concern in 'Why Waste our Time on Rewrites',

\footnotetext{
${ }^{28}$ For an overview of the so-called 'Manipulation School' see Mary Snell-Hornby, The Turns of Translation Studies (Philadelphia, Amsterdam: J. Benjamins Pub, 2006), pp. 47-50.

29 André Lefevere, 'Translated Literature: Towards an Integrated Theory', The Bulletin of the Midwest Modern Language Association, Vol. 14, No. 1 (Spring, 1981), p. 72.
} 
his contribution to the successful 1985 collection of essays The Manipulation of Literature, edited by Theo Hermans. But it was only with his 1992 monograph, Translation, Rewriting and the Manipulation of Literary Fame, that Lefevere presented a full-scale analysis of rewriting. The book launched a new and influential Translation Studies series edited by Lefevere himself and Susan Bassnett.

In the book's introduction Lefevere and Bassnett wrote: 'Translation is, of course, a rewriting of an original text. All rewritings, whatever their intention, reflect a certain ideology and a poetics and as such manipulate literature to function in a given society in a given way'. ${ }^{30}$ This assumption was based on the conviction, already expressed by late Russian formalists and Polysystem theorists, that 'the social norms and literary conventions in the receiving culture ("target" system) govern the aesthetic presuppositions of the translator and thus influence ensuing translation decisions ${ }^{\prime}{ }^{31}$ Lefevere confirmed the validity of this argument by emphasizing that

the process resulting in the acceptance or rejection, canonization or non canonization of literary works is dominated not by vague, but by very concrete factors that are relatively easy to discern as soon as one decides to look for them, that is as soon as one eschews interpretation as the core of literary studies and begins to address issues such as power, ideology, institution and manipulation. (2)

30 André Lefevere, Translation, Rewriting and the Manipulation of Literary Fame (London: Routledge, 1992), p. VII. Further page references are included parenthetically in the text.

31 Edwin Gentzler, Contemporary Translation Theories (Clevedon, England, Buffalo, N.Y.: Multilingual Matters, 2001), p. 108. 
The influence of late Russian formalists, and in particular the legacy of Tynjanov, is clearly evident in Lefevere's notion of rewriting as the 'motor force behind literary evolution' (2).

Manipulation theorists understood rewriting as a process operating between the poles of innovation and repression. This is how Bassnett and Lefevere put it:

Rewriting is manipulation, undertaken in the service of power, and in its positive aspect can help in the evolution of literature and society. Rewriting can introduce new concepts, new genres, new devices and the history of translation is the history of literary innovation, of the shaping power of one culture upon another. But rewriting can also repress innovation, distort and contain, and in an age of ever increasing manipulation of all kinds, the study of the manipulation processes of literature as exemplified by translation can help us towards a greater awareness of the world in which we live. (1)

Lefevere's case studies mostly exemplify this repressive side of rewriting, where the activity of 'professionals' (rewriters operating within the literary system: critics, reviewers, editors, translators and so on) and of 'patrons' (rewriters operating outside the literary system: political and economical institutions, churches and so on) is almost entirely regulated by the dominant poetics or ideology of a certain time and of a certain society. The power exerted by professionals and patronage is conceived by Lefevere as two-fold, according to the well-established Foucauldian formula: 'what makes power hold good, what makes it accepted, is simply the fact that it doesn't only weigh on us as a force that says no, but that it traverses and produces things, it induces pleasure, forms knowledge, produces discourse' (15). 
Lefevere also argued for a historicization of rewriting. While it has always been central to Western culture, rewriting has played a crucial role from the middle of the nineteenth century, when it started to become what it is today: 'the lifeline that more and more tenuously links "high" literature to the non-professional reader' (4). Hence, Lefevere set out his scholarly agenda:

Since non-professional readers of literature are, at present, exposed to literature more often by means of rewritings than by means of writings, and since rewritings can be shown to have had a not negligible impact on the evolution of literature in the past, the study of rewritings should no longer be neglected. Those engaged in that study will have to ask themselves who rewrites, why, under what circumstances, for which audience. (7)

This agenda turned out to be very successful and intersected important developments in literary theory and in textual criticism. ${ }^{32}$ Nonetheless, Lefevere's theoretical model is still inadequate to describe some profound dynamics underlying the process of rewriting. Some scholars, such as Theo Hermans and Dimitris Asimakoulas, have already highlighted a number of difficulties in Lefevere's method - particularly the

\footnotetext{
${ }^{32}$ Lefevere's approach shares some echoes, for instance, with Jerome McGann's A Critique of Modern Textual Criticism (Chicago: University of Chicago, 1983), a revolutionary study in the field of textual criticism, mainly devoted to the vexed problems of authorship and final authorial intentions. The text, McGann argued, is really 'an actual productive process' characterized by 'the translation of an initially psychological phenomenon (the "creative process") into a social one (the literary work)', p. 63. The recognition of the social constraints embedded in literary production inaugurated a new sociology of the text - cf. Donald F. McKenzie, Bibliography and the Sociology of Texts (Cambridge: Cambridge University Press, 1999) - and put into question the Romantic notion of the author as 'solitary genius' cf. Jack Stillinger, Multiple Authorship and the Myth of Solitary Genius (Oxford: Oxford University Press, 1991) and Zachary Leader, Revision and Romantic Authorship (Oxford: Oxford University Press, 1996).
} 
vagueness of his terminology and some inconsistencies in his analyses. ${ }^{33}$ Here I want to focus attention on the notion of rewriting that he offered.

While it has been claimed that Lefevere approached translation and other types of rewriting 'with the sort of analytical sophistication that is usually reserved for original composition, ${ }^{34}$ in his case studies rewriting is nonetheless understood as a practice distinct from the practice of writing. Indeed, his investigation 'deals with those in the middle, the men and women who do not write literature, but rewrite it' (1, my emphasis). He argues that 'the non-professional reader increasingly does not read literature as written by its writers, but as rewritten by its rewriters' (4). Common experience, however, shows that it is often difficult to set the boundaries between writing and rewriting. Let us take, for example, Anne Frank's 'auto-editing', which is discussed in one of Lefevere's case studies. Lefevere posits that this is an example of rewriting performed for personal and literary reasons. But who can say, along the creative journey of a writer, where writing ends and rewriting begins? When - and where - did Anne Frank stop being a writer and give herself over to rewriting? Leaving aside the theoretical tenets of deconstruction according to which there is no writing ex-nihilo, I would suggest that rewriting is a crucial dimension of the overall writing process, and all the more so for 'the men and women who write literature'. To

\footnotetext{
33 See Theo Hermans, Translation in Systems. Descriptive and System-oriented Approaches Explained (Manchester: St. Jerome, 1999), pp. 124-129; Dimitris Asimakoulas, 'Rewriting', in Routledge Encyclopedia of Translation Studies, ed. by Mona Baker and Gabriela Saldanha, $2^{\text {nd }}$ ed. (New York: Routledge, 2009), pp. 241-245.

${ }^{34}$ Lawrence Venuti, The Translation Studies Reader (New York: Routledge, 2004), p. 197.
} 
put it in Lefevere's terms, rewriting deals with 'those in the extremes' as much as with 'those in the middle'.

It seems to me that the underlying problem in the model offered by Lefevere rests in the conception of rewriting as a practice rather than as a process. Lefevere is aware of the social constraints that make rewriting possible or impossible, the power exerted by ideology and poetics over the task - the practice - of translators, editors, literary critics and so on. But what about the process of rewriting itself? Is it possible to theorize a 'rhetoric of rewriting'? What can be said about the tantalizing desire to retell, to better grasp - or perhaps to police - what has been previously written - the drive for (re)writing over and over again?

\section{(Re)writing}

The interplay between writing and rewriting is now more and more generally accepted. One example is offered by contemporary Translation Studies interested in exploring creative aspects in translation and translating aspects in writing. ${ }^{35}$ It is also noteworthy how professional translators, reflecting on their own work, have started to claim the term 'writer' for themselves. Consider this eloquent passage by Edith Grossman:

I believe that serious professional translators, often in private, think of themselves - forgive me, I mean ourselves - as writers, no matter what else may cross our mind when we ponder the work we do, and I also

\footnotetext{
${ }^{35}$ See, for example, the papers collected in The Practice of Literary Translation: Constraints and Creativity, ed. by Jean Boase-Beier and Michael Holman (Manchester: St. Jerome Publishing, 1998).
} 
believe we are correct to do so. Is this sheer presumption, a heady kind of immodesty on our part? What exactly do we literary translators do to justify the notion that the term 'writer' actually applies to us? Aren't we simply the humble, anonymous handmaids-and-men of literature, the grateful, ever-obsequious servants of the publishing industry? In the most resounding yet decorous terms I can muster, the answer is no, for the most fundamental description of what translators do is that we write - or perhaps rewrite - in language $B$ a work of literature originally composed in language A, hoping that readers of the second language - I mean, of course, readers of the translation - will perceive the text, emotionally and artistically, in a manner that parallels and corresponds to the esthetic experience of its readers. This is the translator's grand ambition. Good translations approach that purpose. Bad translations never leave the starting line. ${ }^{36}$

Rewriting encompasses a wide range of textual practices, but while each of these practices has norms of production, methodologies, possibilities and limits that may be unique to it, all of them are implicitly concerned with signification - with the meaning-making process of (re)writing. What is preserved or highlighted, then, in the imperceptible movement from one text to the other? What is downplayed or discarded? How is meaning displayed or displaced? And what happens when the nature of the reference to be rewritten turns out to be particularly elusive, ineffable, ungraspable - challenging the very possibility of rewriting? These are the questions that motivate my study.

In the next chapter I seek to answer these questions by looking at Katherine Mansfield's own rewriting of notebook entries into works of fiction. I will focus, in particular, on 'An Indiscreet Journey' (1915), 'The Woman at the Store' (1912) and

\footnotetext{
${ }^{36}$ Edith Grossman, Why Translation Matters (New Haven: Yale University Press, 2010), pp. 6-7.
} 
'The Garden Party' (1921). 'An Indiscreet Journey' and 'The Woman at the Store', with their autobiographical background, are two well-known examples of Mansfield's reuse of raw notebook material. However, the ways in which Mansfield translated her entries into these stories have never been fully analysed and described. Indeed, what my analysis attempts to illustrate here is also how much more there is for Mansfield scholars to investigate in this regard. The rewriting process underlying 'The Garden Party' is more subtle and enables me to introduce a crucial theme that will run through this study: the relationship between rewriting, death and survival. 


\title{
Chapter Two
}

\section{'Until I simply exhaust my store': Writing, Rewriting and Working-through}

\begin{abstract}
An event gains meaning by its repetition, which is both the recall of an earlier moment and a variation of it: the concept of repetition hovers ambiguously between the idea of reproduction and that of change, forward and backward movement.
\end{abstract}

Peter BRoOKs

'The line between a jotting in a Mansfield notebook and the first moving towards her own kind of fiction is at times a surprisingly fine one'. ${ }^{1}$ With this observation, Vincent O’Sullivan highlighted a particular aspect of Katherine Mansfield's notebooks. They were not so much the on-going record of an inner life as the workshop of a writer; they were repository of her own experiments with style, the place where she would store countless 'preludes' of stories: beginnings, germinal plots, character outlines, vignettes, literary exercises - stepping stones towards fiction. This workshop testifies to Mansfield's constant and often frustrated effort to accomplish her celebrated 'kind of special prose' (KMN2, 33).

The workshop of the writer often yields to the diary entries of the woman, but even these personal jottings turn out to be literary occasions rather than withdrawals

\footnotetext{
${ }^{1}$ Vincent O'Sullivan, introduction to Katherine Mansfield, The Aloe (Wellington: Port Nicholson Press Limited, 1982), p. 8.
} 
into self-contemplation. Some diary entries concerning Mansfield's health problems are illuminating: 'Lumbago: this is a very queer thing. So sudden, so painful. I must remember it when I write about an old man' (KMN2, 319); 'and my sciatica! Put it on record, in case it ever goes, what pain it is. Remember to give it to someone in a story one day' $(K M N 2,323)$. More literary than diaristic are also the short but vivid descriptions of the people she was close to. Consider, for example, this note on Ida Baker (L.M.)', Mansfield's 'wife': 'L.M. is a very tragic figure. Remember her eyes the pupils dark - black - and her whiteness. Even her hair seems to grow pale. She folded the quilt and held it in her arms as though it was a baby' (KMN2, 228). Sometimes the reflection of the writer develops into full-blown literary portraits, well spiced with Mansfield's distinctive humour:

'Does nobody want that piece of bread and butter?' says L.M. You would really think from her tone that she was saving the poor little darling from the river or worse, willing to adopt it as her own child and bring it up so that it never should know it was once unwanted. She cannot bear to see solitary little pieces of bread and butter or lonely little cakes - or even a lump of sugar that someone has cruelly, heartlessly left in his saucer. And when you offer her the big cake, she says resignedly: 'Oh, well, my dear, I'll just try', as though she knew how sensitive and easily hurt the poor old chap's feelings were, if he's passed by. After all, it can't hurt her.

L.M is also exceedingly fond of bananas. But she eats them so slowly, so terribly slowly. Ah, they know it - somehow they realize what is in store for them when she reaches out her hand. I have seen bananas turn livid with terror, or grow pale - pale as ashes. (KMN2, 203)

\footnotetext{
${ }^{2}$ L.M. stands for Lesley Moore: this was Ida Baker's nickname in Mansfield's letters and journals. Lesley was the name of Mansfield's brother and Moore that of Ida's mother maiden name.
} 
Katherine Mansfield was 'a writer first and a woman after'3 in every single drop of her ink.

The line separating Mansfield's jottings from her fiction was surprisingly fine but also surprisingly fertile. Mansfield was quite aware of the confessional and sentimental temptations lurking at the corners of writing. She managed to eschew them, most of the time, by 'translating' her journal entries into the literary form of her short-stories. It is in this movement that the rewriting process occurs.

In this chapter I follow the ebb and flow, as it were, of Mansfield's rewriting process. Her stories, I want to suggest, are particularly valuable for my inquiry not simply because they are often the result of an actual rewriting process, but also because, like rewriting, they are deeply concerned with the question of meaning. Mansfield had a constant rhetorical and ethical preoccupation with meaning, with its display and displacement, with the complex relationship between reference and its representation. Her stories, in other words, talk about rewriting.

\section{Indiscreet journeys: the rhetoric of rewriting ${ }^{4}$}

Like an elopement

The events of Mansfield's life from the late 1914 to February 1915 are well documented in her journal entries. This is a period of crisis and sentimental distress

\footnotetext{
${ }^{3}$ Katherine Mansfield, Collected Letters of Katherine Mansfield, ed. by Vincent O'Sullivan and Margaret Scott, 5 vols (Oxford: Oxford University Press, 2008), IV, p. 13.

4 An extended version of this section appeared as 'Indiscreet Journeys: Rewriting Katherine Mansfield', in Authorial and Editorial Voices in Translation: Editorial and Publishing Practices, ed. by Hanne Hansen and Anna Wegener (Montréal: Les Éditions québécoises de l'œuvre, 2013).
} 
for Mansfield and her lover, John Middleton Murry. At the same time, from across the English Channel, a charming man starts sending passionate letters to her: his name is Francis Carco (1886-1958), a writer whom Murry himself had introduced to Mansfield in 1912 and who is now serving as a corporal in a place called Gray, in the French war zone. Mansfield is haunted by Carco's 'warm sensational life' (KMN1, 285). She gets her photo taken to be sent to him, reads his last novel, and tries to talk to Murry about her correspondence. At times, thinking about her John 'Jack' Murry, Mansfield is torn between love and disillusion: 'I had such a longing to kiss Jack and say Goodbye Love' (KMN2, 3-4). From 13 January 'Jack has got his own room' $(K M N 2,4)$. The day after, Mansfield receives a letter from Carco, who once again asks her to join him in France. 'This is going to be a very difficult business', (KMN2, 9) Mansfield admits. The war zone was indeed forbidden to women; nonetheless, Mansfield summons up her courage: on 16 February she is in Paris and three days later, fooling the French Army Officials, she reaches Gray.

Mansfield leaves generous traces of this daring adventure in one of her notebooks (KMN2, 1-12). On 20 February, a Saturday morning, waiting for her dejeuner, she jots down her thoughts on the 'queer night' (KMN2, 9) she has just spent with Carco. Her heart feels heavy; she is frightened that something might happen to him because of her visit ('I cant bear to think of him in prison', KMN2, 9); ${ }^{5}$ besides, she starts doubting her feelings: 'I don't really love him now I know him, but

\footnotetext{
${ }^{5}$ The non-standard spelling in this and other passages represents Mansfield's usus scribendi in her notebooks as faithfully transcribed by Scott in her edition.
} 
he is so rich and so careless - that I love' (KMN2, 9). The notebook also contains two draft letters - one addressed to 'Jaggle' Murry, the other to Frieda Lawrence. In the former, Mansfield describes the 'awful moments' $(K M N 2,9)$ of her trip, and how she 'dashed off like the wind' with him in a faded cab, toward a 'large white house' (KMN2, 9-10). In the latter, not much is added: Mansfield goes back over her 'dreadful adventures' $(K M N 2,10)$ again and concludes with the image of 'le petit soldat joyeaux et jeune' $(K M N 2,10)$.

The notebook also records a longer entry, in which Mansfield gives an accurate account of her journey, dwelling on the description of places she saw and the people she met, the arrival in Gray, her meeting with 'F.' Carco, the furtive kisses they exchange in the cab, and their tearing away to the white house; 'it was like an elopment' $(K M N 2,11)$, she finally declares. Shut alone in their room, the lovers press 'against each other a long long kiss' (KMN2, 11). After dinner they lock themselves in their room again:

A whole life passed in the night: other people other things, but we lay like 2 old people coughing faintly under the eiderdown, and laughing at each other and away we went to India, to South America, to Marseilles in the white boat \& then we talked of Paris \& sometimes I lost him in a crowd of people \& it was dark \& frightening, \& then he was in my arms again \& we were kissing. (KMN2, 12)

Mansfield left France for England after four nights, disillusioned as a lover but with good copy for her work. The trip to Gray would indeed represent the 
autobiographical background of 'An Indiscreet Journey', ${ }^{6}$ a 1915 story published posthumously in 1924. Mansfield derived the plot of the story from her own experience, which she developed into a fictional story. In this process, she minimized any explicit reference to the relationship between the character of the woman travelling to the front and 'the little corporal'. This choice might be interpreted as a case of auto-censorship, but Mansfield's intention, I would argue, was more sophisticated.

\section{Crossing (out) the line}

Indeed, part of the allure of the fictional story rests in the tension between background and foreground - between what is deliberately left untold (the main purpose of the trip - the elopement) and what is profusely told (the description of the journey itself). The anonymous female narrator travelling in the war zone is officially visiting her aunt, but the reader infers the true motive of her journey by deciphering several clues dropped throughout the story. The girl wears a Burberry trench coat, which is described as the 'perfect and adequate disguise', 'the sign and the token of the undisputed venerable traveller' $(C F 1,439)$. Her clandestine attitude is suggested to the reader when she faces the police at the Metro and the colonels at her arrival, or when she resists the nosy lady seated opposite her in the train carriage. Her anxiety is betrayed when she rehearses the part of the niece: 'Ah, mon Dieu - I had forgotten the

\footnotetext{
${ }^{6}$ Katherine Mansfield, 'An Indiscreet Journey', in The Collected Fiction of Katherine Mansfield, ed. by Gerri Kimber and Vincent O'Sullivan, 2 vols (Edinburgh: Edinburgh University Press, 2012), I, pp. 439-451. Further references are cited parenthetically as CF1 (Vol. I) and CF2 (Vol. II) with the page number.
} 
name of my uncle and aunt again! Buffard, Buffon - what was it? Again I read the unfamiliar letter in the familiar handwriting' $(C F 1,442)$. Camouflage is corroborated by a narration that hints rather than tells: the characters are nameless or have their name replaced by an epithet - 'St. Anne', the 'seagull', the 'bayonet', 'God I' and 'God II'. Also, the story is clearly set in France, but the toponyms (Gray and Châteaudun) are replaced with the letters $\mathrm{X}$ and $\mathrm{XYZ}$. The dominant figure of speech, right from the beginning, is the simile: the comparison of one thing with another points to the narrator's escape to a different - fictional - level, which makes the reader suspicious of the narrator's reliability. At the end of the first section of the story, the two lovers are shut alone in a room. At this point a less gifted writer would have used the manuscript material of the love scene and lingered on it; instead, Mansfield wraps the scene up with a single, sly innuendo: 'Down went the suit-case, the postman's bag, the Matin. I threw my passport up into the air, and the little corporal caught it' (CF1, 445). The passport - the object that symbolizes the threatened identity of the girl - is now in safe hands: nothing else is added; everything is understood by the reader.

All these elements contribute to a sophisticated narrative where everything is simultaneously told and untold. Mansfield focuses her fiction on the journey itself rather than on the purpose of it, a strategy that seems to stem from a swift remark recorded in the notebook: 'The curious thing was that I could not concentrate on the end of the journey' $(K M N 2,10)$. The narrator swings between display and displacement, showing and concealment, holding onto the details of her journey to divert attention from her personal and hazardous situation as a character. This 
strategy is confirmed by the ways in which Mansfield rewrites her journal entries and transfers them into her fiction. The following table shows some example of this process (the bold face is mine):

\section{The Katherine Mansfield Notebooks}

A little boy very pale running from table to table taking the orders. [...] The little boy poured me out a glass of horrible black coffee. $(K M N 2,10)$

In the porch an old man arrived with a panier $[s i c]$ of brown spotted fish. Large fish - like the fish one sees in glass cases swim through forests of beautiful pressed seaweed. ... the old man stood humbly waiting for someone to attend to him, his cap in his hands - as though he knew that the life he represented in his torn jacket with his basket of fish - his peaceful occupation - did not exist any more [sic] \& had no right to thrust itself here. (KMN2, 10-11)

We arrived at Gray \& one by one like women going in to see we slipped through the door into a hot room completely filled with 2 tables \& two colonels, like colonels in comic opera. Big shiny grey whiskered men with a touch of burnt red in the cheeks, both smoking, one a cigarette with a long curly ash hanging from it. He had a ring on his finger. Sumptuous \& omnipotent he looked. I shut my teeth. I kept my fingers from trembling as I handed the passport \& the ticket. It wont do, it wont do at all, said

\section{An Indiscreet Journey}

A little boy, very pale, swung from table to table, taking the orders, and poured me out a glass of purple coffee. $(C F 1,441)$

Suddenly in the doorway I saw someone with a pail of fish - brown speckled fish, like the fish one sees in a glass case, swimming through forests of beautiful pressed sea-weed. He was an old man in a tattered jacket, standing humbly, waiting for someone to attend to him. A thin beard fell over his chest, his eyes under the tufted eyebrows were bent on the pail he carried. He looked as though he had escaped from some holy picture, and was entreating the soldiers' pardon for being there at all. (CF1, 442)

It was a hot little room completely furnished with two colonels seated at two tables. They were large grey-whiskered men with a touch of burnt red on their cheeks. Sumptuous and omnipotent they looked. One smoked what ladies love to call a heavy Egyptian cigarette, with a long creamy ash, the other toyed with a gilded pen. Their heads rolled on their tight collars, like big over-ripe fruits. I had a terrible feeling, as I handed my passport and ticket, that a soldier would step forward and 
my colonel, \& looked at me for what seemed a long time in silence. His eyes were like 2 grey stones. He took my passport to the other colonel who dismissed his objection, stamped it \& let me go. I nearly knelt on the floor. F. terribly pale. $\mathrm{He}$ saluted, smiled, and said turn to the right \& follow me as though you were not following. (KMN2, 11)

When we came out stars were shining, through wispy clouds, and a moon hung like a candle flame over the ponte [sic] church spire. (KMN2, 11-12) tell me to kneel. I would have knelt without question.

'What's this?' said God I., querulously. He did not like my passport at all. The very sight of it seemed to annoy him. He waved a dissenting hand at it, with a 'Non, je ne peux pas manger ça' air.

'But it won't do. It won't do at all, you know. Look, - read for yourself,' and he glanced with extreme distaste at my photograph, and then with even greater distaste his pebble eyes looked at me. [...]

Terribly pale, with a faint smile on his lips, his hand at salute, stood the little corporal. I gave no sign, I am sure I gave no sign. He stepped behind me. (CF1, 443-444)

Outside, stars shone between wispy clouds, and the moon fluttered like a candle flame over a pointed spire. $(C F 1,449)$

Mansfield rewrites her raw jottings according to the narrative strategy I have outlined, emphasizing the details of the story over its plot. Verbs, nouns, adjectives and images are meticulously altered with the purpose of enhancing visual representation of things and actions: 'to run' becomes 'to swing'; the 'horrible black coffee' is shaded to 'purple coffee'; 'panier of fish' is changed to the more precise 'pail of fish'; the adjectives 'spotted' and 'torn' are replaced with the less common 'speckled' and 'tattered'; the 'cigarette with a long curly ash hanging from it' is revised into 'what ladies love to call a heavy Egyptian cigarette, with a long creamy ash'; the '2 grey stones' eyes of the colonel are rendered as 'pebble eyes'; the 'smil[e]' of Francis turns into the more 
plausible 'faint smile' of the little corporal; the cursory record of dialogues in the notebook gives way to a vivid dramatization; and in the fictional story the moon does not simply 'hang', but 'flutter[s]'.

'An Indiscreet Journey' exemplifies the fundamental rhetoric of rewriting, which rests in the tension between foreground and background, the display and displacement of meaning. But rewriting is also the frustrated attempt to master a meaning that is perceived as ineffable or ungraspable - a reference that defies the very possibility of rewriting. Let us see how Mansfield faced this dilemma in two of her great stories: 'The Woman at the Store' (1912) and 'The Garden Party' (1922).

\section{Writing in a liquid light ${ }^{7}$}

Display and displacement in 'The Woman at the Store'

'The Woman at the Store's is usually read for its relation to the Fauvist and Bergsonian ideas promoted by Rhythm, the magazine in which the story first appeared. It is also read for the issues of gender and cultural identity that it implies, or for its relation to 'colonial writing' - whose features Mansfield would subvert' or deliberately exaggerate in order to meet the expectations of the English audience of

\footnotetext{
${ }^{7}$ An earlier version of this section appeared as 'From the Store to the Story: Katherine Mansfield and the Question of Rewriting', in Katherine Mansfield Masked and Unmasked (Special Issue), Journal of New Zealand Literature, ed. by Charles Ferrall, Anna Jackson, Harry Ricketts, Marco Sonzogni and Peter Whiteford, No. 32: 2 (2014).

${ }^{8}$ Katherine Mansfield, 'The Woman at the Store', in The Collected Fiction of Katherine Mansfield, I, pp. 268-277.

${ }^{9}$ Cf. Lydia Wevers, 'How Kathleen Beauchamp Was Kidnapped', in Critical Essays on Katherine Mansfield, ed. by Rhoda B. Nathan (New York: G.K. Hall, 1993), pp. 37-47.
} 
the time. ${ }^{10} \mathrm{I}$ am going to read this story in relation to Mansfield's source text, 'Notebook 2', ${ }^{11}$ and thereby indicate some hidden motives of Mansfield's discourse.

The basic material of the plot is simple. Three riders (Hin, Jo, and the unnamed female character who tells the story) are heading for a store in the utter backblocks of New Zealand; they are exhausted, their packhorse is sick and they want to stop there for the night. Hin, who has been to the store before, excites the imagination of Jo by depicting the owner's wife as beautiful. Yet, on their arrival, the Woman appears anything but appealing: 'a hungry bird', 'a figure of fun' $(C F 1,270)$. She is alone with her child and a dog; her husband, she says, is 'away shearin" (CF1, 279). While Jo is titivating himself with the purpose of seducing her ('Dang it! She'll look better by night light', $C F 1,272)$, Hin and the narrator speculate about the Woman's past. Hin remembers when the Woman used to work as a 'barmaid down the Coast' and be 'pretty as a wax-doll' (CF1, 272); he is convinced that her husband 'cleared out and left her' $(C F 1,272)$. At night the Woman shares a bottle of whisky with the visitors. In an erratic drunken monologue she reveals that she has had four miscarriages in six years, and blames her husband for ruining her life and leaving her alone. Her child, who is drawing in the same room, suddenly decides that she is going to draw 'what you told me I never was to' $(C F 1,275)$. 'I'll smack you with yer clothes turned up if

\footnotetext{
${ }^{10}$ Cf. Mark Williams, “"The Artificial and the Natural”: The Development of Katherine Mansfield's Prose Style', in Telling Stories: Postcolonial Short Fiction in English, ed. by Jacqueline Bardolph (Amsterdam - Atlanta: Editions Rodopi B.V., 2001), pp. 357-378; See also Jane Stafford and Mark Williams, 'Katherine Mansfield: A Modernist in Maoriland', in Maoriland: New Zealand Literature 1872-1914 (Wellington: Victoria University Press, 2006), pp. 142-170.

${ }^{11}$ Katherine Mansfield, The Katherine Mansfield Notebooks, I, pp. 135-167. Mansfield kept this notebook during her 1907 camping trip through the North Island of New Zealand.
} 
yer say that again' $(C F 1,275)$, reacts her mother. The conversation is then interrupted by a thunderous storm. The Woman suggests that they should sleep inside and not in their tent as they have planned, and sends Hin, the narrator and her child to sleep in the store. Once there, the fellow travellers make fun of Jo and the Woman, who are going to sleep together. Provoked by their laughter and trembling with rage, the child does what her mother has forbidden her to do: she draws 'the picture of a woman shooting at a man with a rifle and then digging a hole to bury him in' $(C F 1,276)$. The story ends at dawn, with Hin and the narrator leaving the store, and Jo saying that he would catch them up later: 'A bend in the road, and the whole place disappeared' $(C F 1,276)$.

As Angela Smith has pointed out, the story is 'full of masks and doubles'. ${ }^{12}$ In the opening scene, for example, white pumice dust covers the riders' face, and Hin is described as 'white as a clown' $(C F 1,268)$. The Woman, is depicted as a ghastly, puppet-like figure: 'you felt there was nothing but sticks and wires under that pinafore' $(C F 1,270)$. The description of human features is given through animal imagery. The three travellers appear to the Woman as 'three 'awks' $(C F 1,269)$; the Woman looks like a 'hungry bird' (CF1, 270); her daughter is 'a rat of a child' (CF1, 271), 'a broody 'en' (CF1, 274), and in her first month of life she 'sickened like a cow' $(C F 1,271)$. The feral background onto which human characters are projected is inhabited by other disturbing creatures: the sick horse (eloquently gendered as

\footnotetext{
${ }^{12}$ Angela Smith, Katherine Mansfield and Virginia Woolf: A Public of Two (New York, Oxford: Clarendon Press, 1999), p. 120.
} 
female); the shrilling larks; the thick spider webs (which have a double in the 'treacle paper' pinned at the curtain of the whare); the 'flies buzzing against the ceiling and dropping on to the table' (CF1,273); the dog, a mangy beast, which is yellow like the Woman's hair and bites fleas like the child bites her nails.

Most of these images - and many others - derive from 'Notebook 2', but Mansfield intensifies their symbolic voltage to suit her narrative strategy. On the one hand, as many critics have observed, the masks and doubles of the story serve to reveal and display meaning, conveying 'a feeling of depletion, degeneration and corruption'. ${ }^{13}$ On the other hand, I would argue, the excessive use of figures and masks points to an opposing strategy, that of the concealment and displacement of meaning. The latter serves to mimic the inability for the narrator fully to grasp and bear witness to an uncanny, unnarratable situation. It is in this tension between display and displacement, knowing and not knowing, that the story exerts its disorientating effect upon the reader; and it is in this impasse between the driving wish for meaning and the frustrated representation of it that one finds the deepest connection between 'The Woman' and 'Notebook 2'.

\section{Unnarratable encounters: Katherine Mansfield in Te Urewera}

'On the journey the sea was most beautiful - a silver point etching and a pale sun breaking through pearl clouds' (KMN1, 135). The opening paragraph of 'Notebook 2'

\footnotetext{
${ }^{13}$ Clare Hanson and Andrew Gurr, Katherine Mansfield (London and Basingstoke: The MacMillan Press LTD, 1981), p. 38.
} 
could not be more antithetical to the abrupt opening of 'The Woman' ('All that day the heat was terrible', KMN1, 268). The eyes of the nineteen-year-old Mansfield are full of expectations and softly roam over the beauties of the New Zealand nature and landscape - the sea, the sun, the 'buffeting and friendly' breeze, the brown paddocks, the flowers, the grey whares 'in the distance' (KMN1, 135). Yet, as Ian Gordon noted, Mansfield's impressions result not in a travel diary but in an 'artist's sketchbook'. ${ }^{14}$ From the very beginning, the point of view of the notebook is that of a budding writer, whose effort of representation seems to be motivated, above all, by the desire to collect 'raw material' for potential, literary reuse. Indeed, 'Notebook 2' is a 'Rough Note Book', as Mansfield states on its front page, and its 'roughness' is signalled by the things and situations listed in her distinctive, swift, asyndetic entries:

The old man, the candle in a tin, the scenery, the old shed, the hot water, the falling, the road - how we sleep. [...]

Came on a peninsula, the purple, the ferns, the clean house, evening, the cream, the wild pigs. [...]

The plain, rain, long unending purple mountains, river ducks, one clump of broom, wild horses, the great pumice fire, lambs in the sun, orchids, fluff in the manuka, snow berries (KMN1, 137-138). ${ }^{15}$

\footnotetext{
${ }^{14}$ Katherine Mansfield, The Urewera Notebook, ed. by Ian Gordon (Oxford: Oxford University Press, 1978), p. 20.

15 The nature of these fragments is even clearer in the 1979 edition of The Urewera Notebook, where Gordon systematically decided to retain the dashes of the original manuscript, whereas Scott replaced them with the comma. The juxtaposition of noun phrases chained together by sole dashes indicates the wide-ranging perspective of Mansfield's mental camera: this is indeed material to be reused in a subsequent stage, where selective strategies are applied.
} 
At times, Mansfield dwells on a particular detail - a scene, a human character, a corner of the landscape - before allowing her prose to develop into literary experimentation. Mansfield's mental camera shifts between foreground and background, zooms in on a 'wonderful huge horsefly', and then out to get 'a little cloud [that] shines in the sunlight' (KMN1, 138). She displays various literary styles, registers, moods; the personal pronouns $I$ and we shade into she and they as she tests the distanced view of third-person narration. Landscape and human features are depicted through erudite formulae, imbued with a decadent sensibility and European cultural references: a valley of bush is named 'Elysian' (KMN1, 139); the New Zealand soundscape is described in European musical terms: 'One sudden exquisite note in the night terza' $(K M N 1,145)$, 'and now the day fully enters with a duet for two oboes - you hear it' (KMN1, 145); the names of Wagner, Wilde, Whitman, Shakespeare, Byron, H.G. Wells, and Maeterlinck crop up in the text; the use of adjectives such as charming ('charming little place', KMN1, 139), exquisite ('the ferns are almost too exquisite', KMN1, 146), perfect ('a perfect panorama of sunset', KMN1, 139), and the preciosity of style are redolent of the decadent, largely European literature in which Mansfield was immersed at that time.

The open exercise of literary devices, however, also points to an underlying failure in Mansfield's signification process: the impossibility of ever fully representing - with the instruments of known literariness - the unsettling places and people that she encounters in Te Urewera. As Stafford and Williams observe: 
Mansfield's response to the land is equivocal and shifting. [...] For Mansfield, the Urewera district and its people, especially when she moves into those places where English is not spoken, are pleasing but also disconcerting. The Maori on one occasion seem 'almost threatening'. The feelings of romantic awe elicited by the scenery unsettle rather than thrill her; she feels the land is withholding something from her, that it contains some secret she cannot penetrate. ${ }^{16}$

A first example of the land's inscrutable nature is provided by the ending of the opening paragraph, where Mansfield writes:

Everywhere on the hills great masses of charred logs - looking for all the world like strange fantastic beasts, a yawning crocodile, a headless horse, a gigantic gosling, a watchdog - to be smiled at and scorned in the daylight, but a veritable nightmare in the darkness. And now \& again the silver tree trunks, like a skeleton army, invade the hills. (KMN1, 136)

The theme developed here echoes the topos, typical of Australian outback fiction, of the weirdness of the bush, while expressing what will turn out to be a deeper preoccupation in Mansfield's fiction. How can a writer bear witness to something that appears 'to be smiled at and scorned in the daylight, but a veritable nightmare in the darkness'?

Recurrent images of death, mourning, strangeness and violence are given as symptoms rather than being fully analysed and understood for what they are: the 'funeral wise' $(K M N 1,135)$ cattle, the 'eerie sound' $(K M N 1,136)$ of the horses, the 'wretched dogs' (KMN1, 138), the monotonous and persistent cry of the birds, the gloomy shades of the bush, the 'almost haunted' $(K M N 1,140)$ whares, the dismal frog

\footnotetext{
${ }^{16}$ Jane Stafford and Mark Williams, 'Katherine Mansfield: A Modernist in Maoriland', p. 159.
} 
croaks, the madly thrilling larks, the mist and thunder, the 'shattering sound of water' (KMN1, 146). When Mansfield explicitly refers to the violent collisions between Maori and Pakeha, she seems to me to displace her own unsettling feelings rather than mythologizing that history of violence: 'Visions of long dead Maoris, of forgotten battles and vanished feuds stirred in me' $(K M N 1,136)$. This history of death and violence can only be grasped, it would seem, in traumatic terms; references are unrecoverable, battles can only be 'forgotten', and feuds 'vanished'. The following passage - written, most likely, at the Waiotapu camp-site, near Rotorua - exemplifies the movement in Mansfield from display to displacement and, ultimately, to perplexed silence:

Mist over the distant hills, the fascinating valleys of toitoi swayed by the wind. Silence again, and a world full of the loneliness and the sweetness of the wild places. Kathie in the morning in the manuka paddock saw the dew hanging from the blossoms \& leaves, put it to her lips \& it seemed to poison her with the longing for the sweet wildness of the plains, for the silent speech of the Silent Places, the golden rain of blossom. (KMN1, 144)

As Stafford and Williams observe, Mansfield 'recognises the beauty of the "wild places" but fears its poison. She is drawn to the unfamiliar land, but it resists her approach. She touches it, but it recoils from her. She puts it into words, but it remains silent'. ${ }^{17}$

'Notebook 2' thus marks Mansfield's early investigation into the possibilities and limits of literary representation.

\footnotetext{
${ }^{17}$ Jane Stafford and Mark Williams, 'Katherine Mansfield: A Modernist in Maoriland', p. 159.
} 
Writing in the New Zealand Sunset

The complex rhetoric enacted in 'The Woman' is summed up by one dominant image: that of light. Light punctuates and structures Mansfield's story, at once piercing and confirming its dark narrative space. Upon the travellers' arrival at the store, 'the sun pushed through the pale clouds and shed a vivid light over the scene. It gleamed on the woman's yellow hair, over her flapping pinafore and the rifle she was carrying' (CF1, 269). The Woman's daughter is also revealed by a source of light: 'through the dark we saw the gleam of the kid's pinafore' $(C F 1,272)$; 'the lamp from the inside of the tent cast a bright light over her' $(C F 1,272)$. Jo wants to seduce the Woman because, after all, 'she'll look better by night light' $(C F 1,272)$. When the visitors and the woman sit around the table at night, 'an oil lamp was set between' them $(C F 1,273)$. Moreover, the suspense of the story is heightened by the building storm with its flashes of lightning: 'A vivid flash of lighting played over the room' $(C F 1,274)$; 'Every moment the lightning grew more and more vivid and the thunder sounded nearer' $(C F 1,274)$; 'The land was as light as though a bush fire was raging' $(C F 1,275)$.

In a story where 'nothing is what it seems', ${ }^{18}$ light, by revealing things but also by slanting the perception of them, is clearly associated with the question of meaning. It is from this perspective that I would interpret the following passage:

\footnotetext{
${ }^{18}$ Angela Smith, Katherine Mansfield and Virginia Woolf, p. 119.
} 
It was sunset. There is no twilight to our New Zealand days, but a curious half-hour where everything appears grotesque - it frightens - as though the savage spirit of the country walked abroad and sneered at what it saw. $(C F 1,271)$

The 'savage spirit of the country' evokes the 'fantastic beasts' imagined by the budding writer in 'Notebook 2'. In the story, however, the theme of the weirdness of the bush, associated with the change of light and therefore with the question of meaning, becomes the metaphor of the epistemological and ethical limbo into which all the elements of narration seem to fall.

In the frightening light of the New Zealand sunset, 'where everything appears grotesque', even the narrator (the one expected to bring meaning - to shed light - on the events) is riddled with ambivalence. As Smith points out, this ambivalence is first of all associated with the narrator's gender identity: she 'seems for the larger part of the story to be a man, travelling with two men whose language suggests an all-male camaraderie'. ${ }^{19}$ The gender ambivalence of the character, also, points to her unreliability as a narrator. She makes strong claims about the Woman's and her daughter's madness ('mad, of course she is mad!', CF1, 271; 'There was no doubt about it, the kid's mind was diseased', $C F 1,274)$, but she fails to fully grasp the real reason for their derangement. Her inability to go beyond superficial knowledge seems to be foreshadowed by the half-asleep dream she has before arriving at the store:

I half fell asleep, and had a sort of uneasy dream that the horses were not moving forward at all - then that I was on a rocking-horse, and my old

\footnotetext{
${ }^{19}$ Angela Smith, Katherine Mansfield and Virginia Woolf, p. 120.
} 
mother was scolding me for raising such a fearful dust from the drawingroom carpet. 'You've entirely worn off the pattern of the carpet,' I heard her saying, and she gave the reins a tug. $(C F 1,269)$

It is as though meaning can only be revealed in dreams, and when the dreamer is a child again. The detail of the worn-off pattern of the carpet suggests the confusion and unreliability of the narrator's 'design', and points, by contrast, to the revelatory drawing of the Woman's daughter at the end of the story. Mansfield entrusts the possibility of providing meaning to 'a mean, undersized brat, with whitish hair, and weak eyes' $(C F 1,272)$. It is this child with 'weak eyes' who reveals the narrator's gender identity that until now has been 'hidden' from the reader:

'I'll draw all of you when you're gone, and your horses and the tent, and that one' - she pointed to me - 'with no clothes on the creek. I looked at her where she wouldn't see me from'. (CF1, 273)

The anagnorisis of the child strengthens the reliability of her drawings - despite the narrator dismissing them as the 'creations of a lunatic with a lunatic's cleverness' $(C F 1,274)$ - and especially of her forbidden one, which coincides with the climax of the story. It is significant that the dreadful truth is only sketched, indirectly suggested to the reader through a child's drawing. The meaning of things slips away; it is displayed - but only for a second; it is buried - like a murdered corpse; it is suppressed, possibly repressed, and ultimately erased: 'A bend in the road and the whole place disappeared' $(C F 1,276)$. 
Post-scriptum: a few notes on a philological dig

In the second half of 'Notebook 2', immediately after the section reporting the camping trip, Mansfield entered an observation that Andrew Bennett considers 'remarkably prescient in its conception of Mansfield's future writing career': ${ }^{20}$

The partisans of analysis describe minutely the state of the soul, the secret motive of every action as being of far greater importance than the action itself. The partisans of objectivity give us the soul of this evolution sans describing the secret process. They convey the state of the soul through the slightest gesture - i.e. realism, flesh covered bones, which is the artists method for me. In as much as art seems to me pure vision I am indeed a partisan of objectivity. (KMN1, 156)

According to Bennett, '[o]ne of the things that mark Mansfield's mature stories is the way that they appeal to but finally resist psychological or psychoanalytic analysis or commentary, the way in which they hint at but also diverge from any appeal to or investigation of the unconscious'. ${ }^{21}$ Similarly, Clare Hanson has argued that the passage suggests 'the central idea [...] that in literature abstract states of mind or feelings should be conveyed through concrete images rather than described analytically. ${ }^{22}$ The relationship between the principle of oblique narration, expressed by Mansfield in this entry, and the narrative strategy enacted in stories like 'The Woman at the Store' is self-evident. Nonetheless, scholars have missed an essential aspect of this text.

\footnotetext{
${ }^{20}$ Andrew Bennett, Katherine Mansfield (Devon: Northcote House, 2004), p. 15.

${ }^{21}$ Andrew Bennett, Katherine Mansfield, p. 15.

${ }^{22}$ Clare Hanson, The Critical Writings of Katherine Mansfield (Basingstoke, Hampshire: Macmillan, 1987), p. 9.
} 
It is a strange text, not only because of its content but also because of the way Mansfield recorded it in her notebook: it appears to have been written upside down, which seems to hint at some different textual status. Why did Mansfield turn her notebook at this point? What sort of text is this? Is it, perhaps, displacing something?

The answer lies in a letter written in June 1908 by Mansfield to her sister Vera:

And have you - I wonder read Guy de Maupassant's Pierre et Jean. It is really a most fascinating book - but I liked best his article in the front on the Novel - and there is positively no difficulty with the language - the French seems to translate itself..$^{23}$

That upside-down text anticipating the achievements of Mansfield's fiction is in fact a translation from the French of Maupassant's essay 'Le Roman' ('The Novel'). The essay was published as foreword to his short novel Pierre et Jean (1888) and this is the excerpt that Mansfield translated in her notebook:

Les partisans de l'analyse demandent que l'écrivain s'attache à indiquer les moindres évolutions d'un esprit et tous les mobiles les plus secrets qui déterminent nos actions, en n'accordant au fait lui-même qu'une importance très secondaire. [...]

Les partisans de l'objectivité (quel vilain mot!) prétendant, au contraire, nous donner la représentation exacte de ce qui a lieu dans la vie, évitent avec soin toute explication compliquée, toute dissertation sur les motifs,

\footnotetext{
${ }^{23}$ Katherine Mansfield, The Collected Letters of Katherine Mansfield (Oxford: Oxford University Press, 1984), I, p. 46 (emphasis added).
} 
et se bornent à faire passer sous nos yeux les personnages et les événements. ${ }^{24}$

The simile of flesh and bone ('flesh covered bones') is also derived from Maupassant:

Ils [les écrivains objectifs] cachent donc la psychologie au lieu de l'étaler, ils en font la carcasse de l'œuvre, comme l'ossature invisible est la carcasse $\mathrm{du}$ corps humain. Le peintre qui fait notre portrait ne montre pas notre squelette. ${ }^{25}$

As early as 1908, Mansfield considered herself a partisan of objectivity, embracing the principle of oblique narration as advocated by the French writer. Art is 'pure vision', the capacity to tell the story of the human soul not through analysis, but by showing the 'slightest gestures' of women and men. This poetics implies a dialectic between display and displacement that is also, as we have seen, at the heart of the rewriting process; in the words of Maupassant:

La vie encore laisse tout au même plan, précipite les faits ou les traîne indéfiniment. L'art, au contraire, consiste à user de précautions et de préparations, à ménager des transitions savantes et dissimulées, à mettre en pleine lumière, par la seule adresse de la composition, les événements essentiels et à donner à tous les autres le degré de relief qui leur convient, suivant leur importance, pour produire la sensation profonde de la vérité spéciale qu'on veut montrer. ${ }^{26}$

Nonetheless, Mansfield's enthusiastic support of objective poetics has also a personal twist:

\footnotetext{
${ }^{24}$ Guy de Maupassant, 'Le Roman', in Romans, ed. by Albert-Marie Schmidt, (Paris: Éditions Albin Michel, 1970), p. 836.

${ }^{25}$ Guy de Maupassant, 'Le Roman', p. 837.

${ }^{26}$ Guy de Maupassant, 'Le Roman’, p. 835.
} 
Yet I cannot take the simile of the soul and the body for the bone is no bony framework. Supposing ones bones were not bone but liquid light which suffuses itself, fluctuates - well and good, but the bones are permanent and changeless - $\therefore$ - - that fails. (KMN1, 156)

In this final, still unarticulated and ultimately abortive gloss, Mansfield anticipates the modernist idea that the human soul, whatever that might be, is not something solid and stable - something that can be objectively represented. Rather, it is elusive, fluctuating, flickering - like the light of the New Zealand sunset; something that can be appropriately defined through the displacement of a rhetorical figure - a synaesthesia. 'Liquid light' is, I think, a suitable definition for Katherine Mansfield's modernist writing; it also suggests the shifty, equivocal relation between reference and representation, writing and rewriting - the slippery luminous path of interpretation.

\section{Trauma and rewriting}

The paradox of rewriting as a process that reveals and curtails meaning can be further and fruitfully understood through the notion of trauma, which has attracted considerable interdisciplinary attention over the past two decades. Trauma describes an event that simultaneously claims and challenges our understanding. This paradoxical situation was first observed by Sigmund Freud in a number of contributions and in particular in his groundbreaking 1920 work, Beyond the Pleasure Principle. Freud, a contemporary of Mansfield, was concerned with the traumatic neuroses affecting the veterans from the Great War. These neuroses consisted of repetitive intrusions - in the form of flashbacks, obsessive thoughts or dreams - of 
horrifying images witnessed at the front. Freud compared war neuroses with accident neuroses and argued that ' $[\mathrm{d}]$ reams occurring in traumatic neuroses have the characteristic of repeatedly bringing the patient back into the situation of his accident, a situation from which he wakes up in another fright'. ${ }^{27}$ Indeed, according to Freud, trauma develops from a 'fright' or 'lack of preparedness' to an overwhelming event, an event that, Cathy Caruth explains, 'is experienced too soon, too unexpectedly, to be fully known and is therefore not available to consciousness until it imposes itself again, repeatedly, in the nightmares and actions of the survivor. ${ }^{28}$ The repetition compulsion that haunts trauma victims is the attempt 'to master the stimulus retrospectively, by developing the anxiety whose omission was the cause of the traumatic event'. ${ }^{29}$

In the second chapter of Beyond the Pleasure Principle, Freud explains repetition compulsion through his famous analysis of the fort/da game. Freud describes a boy of one and a half (his grandson), who has the habit of throwing objects away, whilst uttering the sound 'oooo'. With the help of the boy's mother, Freud understands that the 'o' sound means fort ('gone' in German). On a second occasion, Freud witnesses the boy throwing a reel over the edge of his cot, uttering 'oooo', and then retrieving the reel with the sound $d a$ ('there'). The little boy, Freud

\footnotetext{
27 Sigmund Freud, Beyond the Pleasure Principle, in The Standard Edition of the Complete Psychological Works of Sigmund Freud (London: Hogarth, 1953-74), vol. 18, p. 13.

${ }^{28}$ Cathy Caruth, Unclaimed Experience: Trauma, Narrative and History (Baltimore and London: Johns Hopkins University Press, 1996), p. 4.

${ }^{29}$ Sigmund Freud, Beyond the Pleasure Principle, p. 32.
} 
speculates, is staging the disappearance and return of his mother. Yet, Freud finally concludes that the act of departure is 'staged as a game in itself and far more frequently than the episode in its entirety, with its pleasurable ending'. ${ }^{30}$ The repetition compulsion is the repetition of an event whose meaning the little boy cannot fully grasp: the enigmatic experience of being abandoned.

The relation between reference and representation in the traumatic context is not straightforward because there is no simple, referential access to the truth of the traumatic event. Rather it is precisely in the form of a knowledge that cannot become 'matter of intelligence ${ }^{31}$ that truth is first experienced at all. It is for this reason that trauma 'requires integration', the 'transformation into a narrative memory that allows the story to be verbalized and communicated'..$^{32}$ The attempt to defy the event's incomprehensibility is possible, however, to the detriment of the trauma's precision: 'the capacity to remember is also the capacity to elide or distort'. ${ }^{33}$ Nonetheless, to bear witness to a trauma is not simply the attempt to make an event meaningful, but also the attempt to transmit its incomprehensible nature. It is in this paradox that the notion of trauma can be used as a powerful analytical framework for the comprehension of the rewriting process. If trauma 'offers the possibility of a speech that is not simply the vehicle of understanding, but also the locus of what cannot yet

\footnotetext{
${ }^{30}$ Sigmund Freud, Beyond the Pleasure Principle, p. 36.

${ }^{31}$ George Bataille, quoted in Trauma: Explorations in Memory, ed. by Cathy Caruth (Baltimore: The Johns Hopkins University Press, 1995), p. 153.

${ }^{32}$ Cathy Caruth, Trauma, p. 153.

${ }^{33}$ Cathy Caruth, Trauma, p. 153.
} 
be understood', ${ }^{34}$ rewriting, in its tension between display and displacement, is the privileged way in which this paradoxical speech can be transmitted.

'The Woman at the Store' exemplifies the traumatic dimension of rewriting in the very rhetoric of its narrative. This is ultimately embedded in the mise en abime of the drawing performed by the woman's daughter at the end of the story. The child's creation - itself a form of rewriting - is like the game of Freud's little boy: it is the attempt to represent - to re-enact, to re-write - an event that remains inaccessible to conscious recall.

I will now turn to 'The Garden Party'. ${ }^{35}$ This celebrated story is a telling example of how personal and historical trauma meets with its rewriting.

\section{The party's leftovers}

In a windless day of early summer, the Sheridans, a middle-class New Zealand family, are preparing for a garden party. Everything seems to be just perfect in this Eden on earth where hundreds of roses 'had come out in a single night' (CF2, 401) and 'bushes bowed down as though they had been visited by archangels' (CF2, 401). But a horrible accident occurs: Mr Scott, a young working-class man living in a little cottage 'just below' the Sheridans, falls off his cart and dies, leaving behind a wife and five children. The news of the tragic accident deeply upsets young Laura Sheridan, who begins to question the appropriateness of throwing a garden party with a man dead

\footnotetext{
${ }^{34}$ Cathy Caruth, Trauma, p. 155.

${ }^{35}$ Katherine Mansfield, 'The Garden Party', in The Collected Fiction of Katherine Mansfield, II, pp. 401-414.
} 
just outside the front gate' (CF2, 407). For her family, however, Laura's reaction is 'absurd' and 'extravagant' (CF2, 407): the garden party must go on, and the sad news ought to be 'forgotten'. The memory of the accident haunts Laura - seeing Laurie, her brother, she 'remembered the accident again' $(C F 2,409)$ - but it is only after the party that the memory of the accident resurfaces: 'I suppose you didn't hear of a beastly accident that happened to-day?' $(C F 2,410)$ asks Mr Sheridan. His wife, in the attempt to resolve her unspoken unease, sends Laura to the cottage with a basket of leftovers.

Laura crosses the broad road and the lane begins, 'smoky and dark' (CF2, 411). The closer she gets to the house the more uncomfortable she feels ('How her frock shone!', CF2, 411). At Scott's house, Laura is invited to come in; she unwillingly follows a woman who speaks in an 'oily voice' $(C F 2,412)$; she finds herself in a 'wretched little low kitchen' $(C F 2,412)$ where another woman sits before a fire; and she finally enters the bedroom where the dead man is lying:

There lay a young man, fast asleep - sleeping so soundly, so deeply, that he was far, far away from them both. Oh, so remote, so peaceful. He was dreaming. Never wake him up again. His head was sunk in the pillow, his eyes were closed; they were blind under the closed eyelids. He was given up to his dream. What did garden parties and baskets and lace frocks matter to him? He was far from all those things. He was wonderful, beautiful. While they were laughing and while the band was playing, this marvel had come to the lane. Happy ... happy. . . . All is well, said that sleeping face. This is just as it should be. I am content. $(C F 2,413)$ 
'Forgive my hat' Laura says to the 'wonderful' corpse; then, passing 'all those dark people' (CF2, 413), she leaves the house. At the corner of the lane she comes across her brother:

He stepped out of the shadow. 'Is that you, Laura?'

'Yes.'

'Mother was getting anxious. Was it all right?'

'Yes, quite. Oh, Laurie!' She took his arm, she pressed up against him.

'I say, you're not crying, are you?' asked her brother.

Laura shook her head. She was.

Laurie put his arm round her shoulder. 'Don't cry,' he said in his warm, loving voice. 'Was it awful?'

'No,' sobbed Laura. 'It was simply marvellous. But, Laurie -' She stopped, she looked at her brother. 'Isn't life,' she stammered, 'isn't life-' But what life was she couldn't explain. No matter. He quite understood.

'Isn't it, darling?' said Laurie. (CF2, 413)

Several elements allow us to read 'The Garden Party' in the context of trauma theory. First, the structure of the story and the ways in which the author deals with space call to mind Freud's definition of trauma as an event that breaks through the protective shield of the mind. Mansfield juxtaposes the 'inside' of the Sheridan property to the 'outside' of the world that begins 'just below in the lane' $(C F 2,410)$. The outside is the place of history, 'disgusting and sordid', where cottages of poor people are 'the greatest possible eyesore'; it is a place inhabited by people speaking 'revolting language'; it is the place where accidents occur. The inside, on the contrary, is an ahistorical place; it is the garden of Eden, inhabited by people who speak a standard, artificial English; it is the place where nothing really occurs. The dreadful news, 
coming from the outside, breaks through the house. When Laura informs her mother of the accident, Mrs Sheridan interrupts her and, alarmed, says: 'Not in the garden'. Although the dreadful event occurs 'just outside the front gate' $(C F 2,407)$, the 'breaking news' eventually penetrates the Sheridans' 'protective shield': the outside has come inside.

The news of the accident is literally forgotten during the party; it is forgotten by Laura's family members and by Laura as well: ' $(C F 2,409)$ it again after the party's over, she decided'. As Caruth explains, it is precisely 'in and through its inherent forgetting that [trauma] is first experienced at all' ${ }^{36}$ And this uncanny forgetfulness haunts Laura even after the party, while she goes with her leftover basket to Scott's house:

Here she was going down the hill to somewhere where a man lay dead, and she couldn't realize it. Why couldn't she? She stopped a minute. And it seemed to her that kisses, voices, tinkling spoons, laughter, the smell of crushed grass were somehow inside her. She had no room for anything else. How strange! She looked up at the pale sky, and all she thought was, 'Yes, it was the most successful party.' $(C F 2,411)$

It is in the ending of the story, however, and in particular in the way the narrator describes the corpse of the dead man and Laura's reaction to it, that Mansfield's writing reveals its profound connections to trauma; and it is at this precise point that trauma meets rewriting.

\footnotetext{
${ }^{36}$ Cathy Caruth, Trauma, p. 8.
} 
The representation of the dead man echoes in fact the representation that Mansfield gave of her brother in her notebooks. In order to understand what ties Mansfield's description to its reference, it is necessary to go back to what Vincent O'Sullivan defined as the 'most severe emotional crisis $^{37}$ of Mansfield's life.

On October 7, 1915, Leslie 'Chummy' Beauchamp, Mansfield's brother, was killed at the front in a hand-grenade accident. After a few weeks of grieving, Mansfield takes her pen up again. She feels 'as much dead as' her brother $(K M N 2,16)$, but she has now a 'duty to perform' (KMN2, 16), a 'sacred debt' $(K M N 2,32)$ towards her brother and homeland. She will write about her New Zealand time 'until I simply exhaust my store' $(K M N 2,32)$. But the task is difficult to carry out: Mansfield is looking for a new form, for a new way of telling stories, for a 'kind of special prose'; ethics and aesthetics are inextricably bound together.

In February 1916, Mansfield jots down an unsettling vision of Leslie:

But then, when I leaned out of the window I seemed to see my brother dotted all over the field - now on his back, now on his face, now huddled up, now half-pressed into the earth. Wherever I looked, there he lay. I felt that God showed him to me like that for some express purpose, and I knelt down by the bed. But I could not pray. I had done no work. I was not in an active state of grace. So I got up finally and went downstairs again. But I was terribly sad.... The night before, when I lay in bed, I felt suddenly passionate. I wanted J. to embrace me. But as I turned to speak to him or to kiss him I saw my brother lying fast asleep, and I got cold. That happens nearly always. Perhaps because I went to sleep thinking of him, I woke and was he, for quite a long time. I felt my face was his

\footnotetext{
${ }^{37}$ Katherine Mansfield, The Collected Letters of Katherine Mansfield, I, p. 187.
} 
serious, sleepy face. I felt that the lines of my mouth were changed, and I blinked like he did on waking. (KMN2, 58; my emphasis)

Christine Darrohn has suggested that Mansfield had this passage in mind when she was writing about the dead man in 'The Garden Party', five years later. ${ }^{38}$ The expression 'there he lay' repeats the expression 'There lay a young man' in the story. The corpse is 'fast asleep', just like Mansfield's brother in the notebook entry. However, as Darrohn has observed, the two images differ significantly. The dead man in 'The Garden Party' is a beautiful, peaceful image, an intact and meaningful body. The image of the brother is, on the contrary, 'purposeless' and disturbing: he is 'dotted all over the field'. When Beatrice Campbell asked for news about Leslie, a few days after his death, Mansfield reportedly answered: 'Blown to bits!'. ${ }^{39}$ The image is utterly referential: Leslie died in a hand-grenade explosion. And the image of the fragmented body - an image that is traumatic by definition ${ }^{40}$ - will haunt Mansfield for years. In the representation of the dead carter, Darrohn argues, there is 'the desire to make the corpse meaningful', the 'attempt to revisit and revise the dead of the Great War', the 'task of rewriting away the damages of war'. ${ }^{41}$

\footnotetext{
${ }^{38}$ Christine Darrohn, 'Blown to Bits!: Katherine Mansfield's "The Garden Party" and the Great War', Modern Fiction Studies, 44: 3 (1998), pp. 514-39.

${ }^{39}$ Anthony Alpers, The Life of Katherine Mansfield (Oxford: Oxford University Press, 1982), p. 183.

40 ' $[\mathrm{t}]$ he traumatic event is first experienced as 'the "shattering" of a previously whole self, Caruth, Unclaimed Experience, p. 131.

${ }^{41}$ Christine Darrohn, 'Blown to Bits!', p. 521, my emphasis.
} 
Trauma, Caruth argues, does not simply define the event itself, but also 'the experience of waking from it' $;{ }^{42}$ trauma is the 'enigma of survival'. ${ }^{43}$ And it is precisely in an enigmatic language that Laura 'wakes up' from her encounter with death: "Isn't life," she stammered, "isn't life-" But what life was she couldn't explain' $(C F 2,413)$. While the dead man is sleeping 'so soundly', Laura experiences her traumatic awakening to life. And it is difficult not to see in this, in the awakening of Laura, Mansfield's own awakening, the realization of that duty that she set herself five years before. Indeed, to rewrite - to awake - is to 'bear the imperative to survive'; ${ }^{44}$ the imperative of finding ways - a 'kind of special prose' - to represent the unrepresentable.

On 9 January 1923, Katherine Mansfield, devastated by pulmonary tuberculosis, had a massive haemorrhage and died before her husband's eyes. It was the beginning of another rewriting.

\footnotetext{
${ }^{42}$ Cathy Caruth, Unclaimed Experience, p. 64.

${ }^{43}$ Cathy Caruth, Unclaimed Experience, p. 58.

${ }^{44}$ Cathy Caruth, Unclaimed Experience, p. 105.
} 


\section{Chapter Three}

\section{After the End: Editing Mansfield}

There is a spiritual obligation upon ourselves to try to dominate a work which so obviously seems to dominate us, which keeps us reading and rereading, ordering and arranging, halfconsciously following half-apprehended clues, patiently yet almost blindly, until we have a sense of the whole work as the tangible garment of a living yet intangible spirit.

JOHN MIDDLETON MURRY

Dark Bogey is a little inclined to jump into the milk jug to rescue the fly.

KATHERINE MANSFIELD

\section{A fitting close}

France, October 1922. Katherine Mansfield is writing what will turn out to be the last page of her Journal. For the past five years she has been trying to cure her tuberculosis and now feels like an 'absolutely helpless invalid'. ${ }^{1}$ She believes that her psyche deserves more attention than her body, thus her decision to join the Gurdjieff Institute for the Harmonious Development of Man, based in Fontainebleau. Her husband, however, does not support her in such an extreme choice. She is aware of this and she is afraid of losing him. At last, determination wins over her fears and the

\footnotetext{
${ }^{1}$ Katherine Mansfield, Journal of Katherine Mansfield, ed. by John Middleton Murry (London: Constable, 1927), p. 248. Further references are cited parenthetically as $J$ with the page number.
} 
spirit of young Katherine breaks out again: 'Risk! Risk anything! Care no more for the opinions of others, for those voices. Do the hardest thing on earth for you. Act for yourself. Face the truth' $(J, 250)$. In spite of everything, she is still longing for a 'full, adult, living, breathing life' $(J, 250)$. The ending of Mansfield's Journal is peacefully triumphant: 'And this all sounds very strenuous and serious. But now that I have wrestled with it, it's no longer so. I feel happy - deep down. All is well' $(J, 251)$.

Two editorial notes frame this final entry. In the first one, the editor says that his wife, intending to send these notes to him, tore them out of her notebook with the following comment: 'These pages from my journal. Don't let them distress you. The story has a happy ending, really and truly' (J, 247). Immediately after Mansfield's last words, the editor steps in one more time: 'With these words Katherine Mansfield's Journal comes to a fitting close' $(J, 252)$. With hindsight, this close is a somewhat fictional one, purposefully placed there by the editor, for Mansfield's manuscripts present further entries written after this one. However, to the unaware reader who has followed Mansfield's 'terribly sensitive mind' $(J, 223)$ up to this point, such a fitting close sounds particularly meaningful: the 'happy ending' of an exceptional, short life.

There is more to say about this last page of the Journal - something that profoundly connects Murry's editing process to Mansfield's life and work. Before turning to this crucial point again, I would like to re-examine the thorny question of the Journal's authorship and discuss a number of significant examples of editorial manipulation. The complex relationship between the power of the editor and the 
authority of the author can help to illustrate some dynamics underscoring the whole text.

\section{Intention, invisibility and potestas}

\section{An authorized intention}

'I had the choice between doing exactly what I liked with her papers and destroying as much as possible. But what did "possible" mean? It was "possible" for me, in one sense, to destroy them all; it was morally impossible for me to do any such thing. Quite deliberately, I chose to preserve them all'. ${ }^{2}$

This note was found among six boxes of papers belonging to John Middleton Murry and acquired in 2012 by the Turnbull Library of Wellington; it describes the dilemma that Murry had to face as Mansfield's literary executor. Indeed, the instructions of his wife sounded anything but final. Mansfield left all her manuscripts to Murry, but asked him to 'publish as little as possible', to 'destroy all' he would 'not use', and to 'leave all fair'. ${ }^{3}$ Given such vague instructions, to preserve Mansfield's papers was the only sensible thing to do; after all, as Claire Tomalin has observed,

\footnotetext{
${ }^{2}$ For a detailed report on this collection of manuscripts, see Fiona Oliver, 'The 2012 Alexander Turnbull Library Mansfield/Murry Acquisition', in Katherine Mansfield Studies, ed. by Janet Wilson, Gerri Kimber and Delia da Sousa Correa, Vol. 5 (Edinburgh: Edinburgh University Press, 2013), pp. 167-180.

${ }^{3}$ Mansfield's instructions appear in two different documents: in a letter addressed to Murry, dated 7 August 1922, and in her official will, drawn up in a hotel in Switzerland on 14 August 1922.
} 
Mansfield 'could have destroyed her papers herself and insisted on Murry returning her letters, had she really been set on their destruction'. ${ }^{4}$

Yet preserving the material is one thing; publishing it, another. In his introduction to the 1927 Journal, Murry claimed that 'at various times in her life Katherine Mansfield entertained the plan of writing for publication "a kind of minute notebook." [...] Three different attempts to carry the plan into execution can be traced in her manuscripts, and once she got so far as to tell me to arrange with a publisher for its publication' ( $J$, xvi). Mansfield's manuscripts, however, tell a different story. The only serious attempt to bring together a literary journal for publication was made by Mansfield in September 1920. After a couple of weeks, however, she abandoned the plan: 'the journal - I have absolutely given up'. ${ }^{5}$ What is really at stake here is not so much Murry's decision to publish Mansfield's private papers (had he not done it, someone else would have) but rather the fact that in publishing the Journal he suggested that this was exactly what the author intended. What is more, Murry produced a trimmed version of Mansfield's manuscripts without giving any explanation for his criteria in terms of selection, arrangement and manipulation of the material. He thus created 'an authorized intention' that most certainly failed to reflect the author's actual intention.

\footnotetext{
${ }^{4}$ Claire Tomalin, Katherine Mansfield, p. 227.

${ }^{5}$ Katherine Mansfield, The Collected Letters of Katherine Mansfield, IV, p. 55.
} 
Murry 'simpatico'

The question of the Journal's authorship can be analyzed through Lawrence Venuti's theory of the translator's invisibility. Invisibility, Venuti argues, is the result of a romantic conception of authorship whereby 'the author freely expresses his thoughts and feelings in writing, which is thus viewed as an original and transparent selfrepresentation, unmediated by transindividual determinants (linguistic, cultural, social) that might complicate authorial originality' ${ }^{6}$ This idea of authorship implies a notion of translation as a derivative 'copy' of the 'original', and the paradoxical attempt to reproduce the 'illusion of authorial presence whereby the translated text can be taken as the original'. In this process, Venuti argues, 'a feeling of simpatico' is involved: 'the translator should not merely get along with the author, nor merely find him [or her] likeable; there should also be an identity between them'. ${ }^{7}$ Venuti's notion of simpatico chimes with Murry's idea of criticism as a 'personal affair', ${ }^{8}$ and the paradoxical nature of romantic originality suggests something of his editorial engagement with Mansfield's work.

As Andrew Bennett puts it, '[w]hile romantic poetry and poetics celebrate the individuality of the author or genius, then, they also assert the essence of genius to be an ability to transcend the self, to go beyond that of which any mortal, fallible

\footnotetext{
${ }^{6}$ Lawrence Venuti, The Translator's Invisibility: A History of Translation (New York: Routledge, 2008), p. 6.

${ }^{7}$ Lawrence Venuti, p. 273, my emphasis.

8 'More and more criticism appears to me an intensely personal affair. [...] The more the critic can lose himself into the object, the more himself he is'. John Middleton Murry, Discoveries: Essays in Literary Criticism (London: Collins, 1924), p. 9.
} 
individual is capable'. ${ }^{9}$ Kant argued that art 'must not have the appearance of being intentional ${ }^{10}$ and all idealistic theories of art have built upon this tenet, severing the genetic link between cause and effect, author and work. For Wordsworth, poetry is not just the 'spontaneous overflow of powerful feelings' but also - and more importantly - 'an emotion recollected in tranquillity'. ${ }^{11}$ The poet is both a transparent individual and someone who manages to transcend his or her individuality, to disappear before writing, to contemplate it 'from the outside'. This notion of the author had a significant impact on the modern and modernist conception of writing: from Flaubert to Eliot, from Mallarmé to Joyce, authors have called for their 'invisibility'. The author is a God-like figure, 'everywhere felt, but never seen', ${ }^{12}$ 'within or behind or beyond or above his handiwork, invisible, refined out of existence, indifferent, paring his fingernails'. ${ }^{13}$

This idea of the Author - an absent-present God - does not refer as much to a historical agent as to a textual principle. Its function consists in selecting and arranging, and it can ultimately be associated with the notion of the 'implied author' theorized by Wayne Booth:

\footnotetext{
${ }^{9}$ Andrew Bennett, The Author (New York: Routledge, 2005), p. 65.

${ }^{10}$ Immanuel Kant, The Critique of Judgement, trans. by James Creed Meredith (Oxford: Clarendon Press, 1952), p. 167.

${ }^{11}$ William Wordsworth, The Oxford Authors: William Wordsworth, ed. Stephen Gill (Oxford: Oxford University Press, 1994), p. 611.

${ }^{12}$ Gustave Flaubert, The Letters of Gustave Flaubert, 1830-1857 (Cambridge, Mass.: Harvard University Press, 1980), ed. by Francis Steegmuller, p. 230.

${ }^{13}$ James Joyce, A Portrait of the Artist as a Young Man (Oxford: Oxford University Press) ed. by Jeri Johnson, pp. 180-1.
} 
The 'implied author' chooses, consciously or unconsciously, what we read; we infer him as an ideal, literary, created version of the real man; he is the sum of his choices. ${ }^{14}$

The author of the Journal of Katherine Mansfield coincides with the diarist - an empirical, historical, self-transparent woman, who pours her 'powerful feelings' into the least literary of the literary genres. But Katherine Mansfield has also the 'same but different' character of a metaphor - an image 'recollected in tranquillity', silently shaped through textual intervention. Katherine Mansfield is an invisible God, an implied author whose name elicits a very specific response. What is unusual in the case of the Journal is the fact that the implied author is not a conscious or unconscious reflection of the author, but the reflection of her editor, the sum of the editor's choices, a creation performed without the author and the reader's knowledge.

\section{Editing Katherine Mansfield: A state of exception}

What kind of authority is an editor allowed to exert over an author's text? If the authority of the author can be described in the political terms of auctoritas, as Mario Barenghi argues, the authority of an editor can be regarded as a form of potestas. ${ }^{15}$ According to the Roman Law, potestas relates to the legal right to do something, but draws its own legitimation from auctoritas, which refers to a moral power, an original

\footnotetext{
${ }^{14}$ Wayne C. Booth, The Rhetoric of Fiction (Chicago: The University of Chicago Press, 1983), pp. 75-76.

${ }^{15}$ See Mario Barenghi, L'autorità dell'autore (Milano: Unicopli, 2000), pp. 62-65.
} 
supremacy, publicly acknowledged and never coercive. ${ }^{16}$ As Giorgio Agamben argues, examples of the relationship between auctoritas and potestas are 'republican Rome's contrast between the Senate and the people' or 'medieval Europe's contrast between spiritual and temporal powers'. ${ }^{17}$ The Mansfield-Murry case can be described, with Agamben, as 'a state of exception' - the contingency where auctoritas and potestas are dangerously 'bound and blurred together'18 in the same individual. ${ }^{19}$ It is on this blurred identity that the editor's invisibility - the 'feeling of simpatico' - is based.

Indeed, the role played by Murry in authoring Katherine Mansfield goes far beyond what is usually understood as 'collaborative editing'. It is, instead, a case of appropriation; an appropriation that begins at the very threshold of the text. The name of the author is included in the title - Journal of Katherine Mansfield - which suggests the displacement of the Subject (the Author) into the subject-matter. This process also reveals the gender issues underlying Murry's potestas: editing Mansfield was, indeed, 'Man's field' - an operation performed by a white, male, heterosexual subjectivity. Many of the excerpts that I am going to discuss can be read through the lenses of gender.

16 '[I]n linea di principio l'auctoritas va distinta dalla potestas o dall'imperium, cioè dal potere coercitivo', Barenghi, L'autorità dell'autore, p. 64.

${ }^{17}$ Giorgio Agamben, State of Exception, trans. by Kevin Attell (London: The University of Chicago Press, 2005), p. 86.

${ }^{18}$ Giorgio Agamben, State of Exception, p. 86.

${ }^{19}$ In addition to what Agamben says, it is interesting to note that one of the rights that a Roman magistrate (endowed with potestas) could assert was the ius edicendi - that is, the right to publish edicts. Potestas is thus connected with the publishing activity, and the notions of auctoritas and potestas could be fruitfully employed to describe the relationship between authors, on the one hand, and editors and publishers, on the other. 
Yet to consider Murry's editorial acts simply against Mansfield's text would be short-sighted. Instead, Murry's appropriation must be considered as a complex discourse working through Mansfield's one. From this point of view, as I will endeavour to demonstrate, appropriation is also a form of response or echo eventually a movement towards a particular form of survival. It is in the paradoxical notion of a loss that is also survival - and vice versa - that the process of rewriting is best understood.

\section{Trimming Mansfield}

December 28. The year is nearly over. Snow has fallen, and everything is white. It is very cold. I have changed the position of my desk into a corner. Perhaps I shall be able to write far more easily here. Yes, this is a good place for the desk, because I cannot see out of the stupid window. I am quite private. The lamp stands on one corner and in the corner. Its rays fall on the yellow and green Indian curtain and on the strip of the red embroidery. The forlorn wind scarcely breathes. I love to close my eyes a moment and think of the land outside, white under the mingled snow and moonlight - the heaps of stones by the roadside white - snow in the farrows. Mon Dieu! How quiet and how patient! $(J, 16)$

This entry closes the 1914 section of the Journal. We can virtually see Mansfield placing her desk in the corner of her room, where she can be 'quite private' and work undisturbed. This passage, however, leaves the reader with an uncomfortable feeling: the kind of feeling that arises when violating a private space. In her 1927 review of the Journal's American edition, Dorothy Parker wrote: 'Journal of Katherine Mansfield is a beautiful book and an invaluable one, but it is her own book, and only her dark, sad 
eyes should have read its words. I closed it with a little murmur to her portrait in the cover. "Please forgive me," I said'. ${ }^{20}$

This emotional reading rests on the recognition of the Journal as the repository of Mansfield's genuine voice. What makes one uncomfortable is also what the common reader usually expects from a writer's journal: the 'true' presence of the author. According to Susan Sontag, we read a writer's journal precisely because of 'the rawness of the journal form even when it is written with an eye to future publication. Here', Sontag continues, 'we read the writer in the first person; we encounter the ego behind the masks of ego in an author's works'. ${ }^{21}$ No tricks seem to be performed here - no literary guile, no fictional defences.

We now know, however, that the 'transparency' of Mansfield's discourse and the ensuing sentimental reception of the Journal are, to a large extent, the result of the editor's invisible intervention. This can be first identified with the severe excision of Mansfield's manuscripts. In Chapter One we have seen that excision may occur in the form of amputation (excision of a significant portion of text) or trimming (multiple excisions performed throughout the text). Telling examples of the first type are the notebooks that Mansfield kept before her 1908 departure for Britain, and which reveal the thoughts of a lively and determined young woman. The vicious (and somehow comical) remarks on her 'tedious' parents; her dealing with the 'powerful

\footnotetext{
${ }^{20}$ Dorothy Parker, The Portable Dorothy Parker (New York: Viking Press, 1973), p. 452.

${ }^{21}$ Susan Sontag, 'The Artist as Exemplary Sufferer', in Against Interpretation and other Essays (London: Penguin, 2009), p. 41.
} 
magnetic chain of sex' $(K M N 1,100)$ and especially with homoeroticism - her 'Oscarlike thread' $(K M N 1,103)$; the passionate - now tender, now desperate, now cynical description of her encounters with an older woman, Edith Bendal; the frank expression of her 'savagely crude' feelings for the Maori girl Maata Mahupuku (KMN1, 104); her yearning for freedom, independence and power, inspired by the reading of early feminist literature (see, for example, her enthusiastic appraisal of Elizabeth Robins in 'Notebook 39') - all these elements were deliberately amputated in Murry's version.

Amputation can also be read as a form of cultural domestication. According to Stafford and Williams:

Murry is largely responsible for lifting Mansfield out of her New Zealand background. Reluctant to allow that Mansfield had any significant life as a writer before she met him, Murry claimed that Mansfield's early life in New Zealand was important because it was something which awakened Love in her'. New Zealand, for him, was less an actual place - with particular and complex social features - than an emblematic stage in the spiritual voyage of Mansfield's life, in which he plays the dominant role, as guide and interpreter. ${ }^{22}$

Insidious forms of domestication also mark the 1954 Journal. Unlike the first edition, the 'definitive' one does include some passages from the Urewera Notebook, but their

\footnotetext{
${ }^{22}$ Jane Stafford and Mark Williams, 'Katherine Mansfield: A Modernist in Maoriland', p. 151.
} 
edited version is often 'anglicised, trite and sentimental', ${ }^{23}$ making Mansfield sound more like a British author than a New Zealand one.

Amputation, operating on a personal and cultural level, contributed to the creation of a 'fictional Mansfield'. Yet what is particularly interesting in Murry's editing is not only what he chose to leave out (to displace - the text in absentia or hypotext), but its dynamic relationship to what he chose to take in (to display - the text in praesentia or hypertext). This relationship can be observed in the process of textual trimming. The excerpts below illustrate the difference between Mansfield's notebooks, as faithfully transcribed by Margaret Scott, and Murry's edited version. The text in bold corresponds to what Murry trimmed away or otherwise manipulated:

The Katherine Mansfield Notebooks

Jack is too far absorbed

1a

Spent another frightful day. Nothing helps or could help me except a person who could guess. And Jack is too far absorbed in his own affairs poor dear to ever do so. Also, he doesn't consider the people within his reach, psychologically speaking. As long as ones mood isn't directed towards or against him hes quite unconscious an unsuspicious. Very sane, but lonely and difficult for me to understand. Saw Campbell and talked L.S.D. Went for a walk \& had some vague comfort given by
$1 \mathrm{~b}$ Spent another frightful day. Nothing helps or could help me except a person who could guess. Went for a walk and had some vague comfort given by some children and the noise of water like rising waves. $(J, 12)$

\footnotetext{
${ }^{23}$ Elizabeth Webby, 'Katherine Mansfield: Everything and Nothing', in 'Meanjin', 41:2 (1982), p. 238.
} 
some children and the noise of water, like

rising waves. (KMN1, 282-83)

\section{I wish I had a lover}

2a

We go to Cornwall tomorrow, I suppose. Ive reread my diary. Tell me, is there a God! I do not trust Jack. Im old tonight. Ah, I wish I had a lover to nurse me - love me hold me - comfort me - to stop me thinking. (KMN1, 284)
$2 b$

We go to Cornwall tomorrow, I suppose. I've re-read my diary. Tell me, Is there a God? I'm old tonight. Ah, I wish I had someone to love me, comfort me and stop me thinking. $(J, 15)$

\section{I don't like Jack's family}

3a

L.M. in her turban with her one big eye \& one little un - do I love her? Not really. And then, just now I mounted to J's room, and opened the door. He was sitting at the table, working. All was in indescribable disorder \& the air was thick with smoke. He held out his hand to me but it was not my place. Oh no - I came away. I came away back into my room - which really has for me a touch of fairy. Is there anything better than my room? Anything outside? The kitten says not - but then it's such a hunting ground for the kitten. The sun throws the shape of the window on to the carpet, \& in those four little square fields the silly flies wander, ever so spied upon by the little lion under the sommier frill ...

I don't like Jack's family. I could never bear to have them live with us - - We'll come to blows about one day. The young brother - so witty that J. choked over his tea, the father who found half a sovereign
$3 b$

My room really has for me a touch of fairy. Is there anything better than my room? Anything outside? The kitten says not - but then it's such a hunting ground for the kitten. The sun throws the shape of the window on to the carpet, $\&$ in those four little square fields the silly flies wander, ever so spied upon by the little lion under the sommier frill ...

Oh dear - oh dear - where are my people? With whom have I been happiest? With nobody in particular. It has all been mush and mushiness. $(J, 97)$ 
in his hip pocket, the mother - jam or marmalade and Aunt Doll. ...

Oh dear, oh dear - where are my people! With whom have I been happiest? With nobody in particular. It has all been mush of mushiness. (KMN2, 143)

What a weight, L.M.

4a

When I get by myself Im always more or less actively miserable. Nobody knows or could know what a weight L.M. is upon me. She simply drags me down \& then sits on me, calm and huge. The strongest reason for my happiness in Paris was that I was 'safe' from her. If it were not for J. I should live quite alone. (KMN1, 280)
$4 \mathrm{~b}$ When I get by myself, I am always more or less actively miserable. If it were not for J. I should live quite alone. $(J, 9)$

\section{The first fiddle}

$5 \mathrm{a}$

Jack would really think me important if I brought him L.S.D. He thinks he's far and away the first fiddle. How he'd love to boast of what I got out of a play. Thats why Im going to start one today. Ill sweat my guts out till I bring it off too. A hideous day. (KMN1, 282)
$5 b$ I am going to start a play today. $(J, 11)$

\section{And I deceived}

$6 a$

Drew came tonight. He's evidently in some kind of trouble with Anne: I don't
$6 \mathrm{~b}$ My mind is full of embroidery, but there isn't any material to hold it together and 
know what. Hes a silly fellow in talk, uneasy and Kosherheaded. J X K W L last night and $I$ deceived. My mind is full of embroidery, but there isn't any material to hold it together and make it strong. (KMN1, 283-84) make it strong. $(J, 13)$

\section{Where is my mate?}

$7 \mathrm{a}$

On the verandah. I don't want a God to praise or to entreat but to share my vision with. This afternoon looking at the primula after the rain. I want no-one to 'dance \& wave their arms' I only want to feel they see too. But Jack won't. Sitting out there in the sun - where is my mate. He wants neither external life nor depression?!!! (KMN2, 187)
$7 \mathrm{~b}$

On the verandah. I don't want a God to praise or to entreat but to share my vision with. This afternoon looking at the primula after the rain. I want no-one to dance and wave their arms. I only want to feel they see, too. $(J, 138)$

\section{No more need of love}

$8 \mathrm{a}$

Father's marriage: news from Marie. Spent the evening writing another column. Help me God! And then L.M. came in to say I was $1 / 2$ an hour slow. Just did it in time. Had talk with L.M. our friendship is returning - in the old fashion. Thought out The Exile. Appalling night of misery deciding that $\mathrm{J}$. had no more need of our love. $(K M N 2,188)$
$8 \mathrm{~b}$ Spent the evening writing another column. Help me God! And then L.M. came in to say I was half-an-hour slow. Just did it in time. Had talk with L.M. Our friendship is returning - in the old fashion. Thought out The Exile. Appalling night of misery. ( $J$, 139)

\section{He rejects my living love}

9a

Worked from 9.30 a.m. to a quarter after midnight only stopping to eat. Finished the
$9 \mathrm{~b}$

Worked from 9.30 till a quarter after midnight only stopping to eat. Finished the 
story. Lay awake then till 5.30 too excited to sleep. In the sea drowned souls sang all night. I thought of everything in my life and it all came back so vividly - all is connected with this feeling that $J$. and I are no longer as we were. I love him but he rejects my living love. This is anguish. These are the worst days of my whole life. (KMN2, 188) story. Lay awake then until 5.30 too excited to sleep. In the sea drowned souls sang all night. I thought of everything in my life, and it all came back so vividly .... These are the worst days of my whole life. $(J, 139)$

\section{I am haunted by him}

$10 \mathrm{a}$

No letter strike still on. A fine day. But what is that to me. I am an invalid. I spend my life in bed. Read Shakespeare in the morning. I feel I cannot bear the silence today. I am haunted by thoughts of Jack perpetually. (KMN2, 189)
$10 \mathrm{~b}$

No letter strike still on. A fine day. But what is that to me. I am an invalid. I spend my life in bed. Read Shakespeare in the morning. I feel I cannot bear the silence today. I am haunted by thoughts. $(J, 141)$

\section{Work vs. Love}

$11 \mathrm{a}$

Work will win if only I can stick to it. It will win after all \& through all. (KMN2, 191)
$11 \mathrm{~b}$

Love will win if only I can stick to it. It will win after all and through all. $(J, 144)$

Mansfield's manuscripts and their 1927 edited version offer two very different 'implied authors'. 1b, for instance, amplifies Mansfield's solipsistic voice - the voice of a delicate creature who finds some 'vague comfort' in the contemplation of children and nature - whereas la displays the thoughts of someone interested in other people and with a certain flair for psychological insight (the character of 'Jack' Murry is here shrewdly sketched out). Moreover, 1a contains a recurring element in Mansfield's notebooks (see also 5a) that is often suppressed in the edited text: L.S.D. The acronym 
stands for Librae, Solidi, Denarii and means 'pounds, shilling and pence' - that is, money. The author's more mundane features are deliberately trimmed away.

A similar process can be witnessed in $2 b$, which provides a good example of Murry's version of Mansfield: a lonely and delicate woman, exposed to existential turmoil. Indeed, the question 'Is there a God?' may suggest an unsatisfied religious yearning, whereas in $2 \mathrm{a}$ it sounds more likely as a sign of impatience, emphasized by the exclamation mark. The comment about Jack is omitted. Here, as in other passages, Murry removes Mansfield's unenthusiastic (if not downright negative) remarks on him. Moreover 2a clearly states that the diarist is not looking for love, but for a lover, whereas in $2 \mathrm{~b}$ one might infer that it is God's love what she is looking for.

In $3 b$ we are again in the 'comfort zone' of the diarist's room. Unlike the text I have quoted at page 68 , however, this entry is significantly trimmed by Murry. In 3a Mansfield talks briefly about L.M. (Ida Baker), then she turns her attention to the husband's messy room. It is only at this point that she goes to her own room. In the edited version Murry preserves only the section of the diarist in her 'fairy' room: once again the romantic solitary genius holds the spotlight.

The suppression of negative remarks on contemporary people (see $4 \mathrm{a}$, another harsh remark about Ida Baker) made the Journal a bewildering reading for those who knew Mansfield well. Lytton Strachey, for example, famously remarked: 'I see Murry lets it out that it was written for publication - which no doubt explains a great deal. But why that foulmouthed, virulent, brazen-faced broomstick of a creature should 
have got herself up as a pad of rose-scented cotton is beyond me'. ${ }^{24}$ This comment is interesting for two reasons: first, it seems to accept Murry's claim on Mansfield's intended publication of her 'journal'; second, it confirms the conviction, already held by Dorothy Parker, of dealing with Mansfield's genuine voice. What is shocking, from Strachey's point of view, is precisely the fact that the Journal's voice and Mansfield's 'foulmouthed' voice belong to the same person.

The examples from 6 to 9 show more cases of censorship achieved by means of trimming. In 6a the letters J X K W L stand very likely for 'Jack and Katherine Were Lovers', and the 'deception' mentioned by Mansfield - curtailed by the editor/husband - is clearly of a sexual nature. In 10b, the substitution of 'Work' with 'Love' ('Love will win if only I can stick to it') casts a sentimental light upon Mansfield's writing and life, projecting an image of her subsequently nourished by generations of readers.

\section{Editing for the Plot}

Murry's editing process clearly produced a new text, a new totality that changed the overall meaning of Mansfield's hypotext. The comparison between Mansfield's manuscripts and their rewriting can be read in metaphoric terms. A metaphor is the substitution of a word or phrase with another word or phrase whose meaning stands in a relation of similarity with the literal meaning of the first. Substitution, however,

\footnotetext{
${ }^{24}$ Quoted in Rhoda B. Nathan, Critical Essays on Katherine Mansfield (New York: G.K. Hall, 1993), p. 64.
} 
does not mean equivalence. As twentieth-century rhetoricians have pointed out, a metaphor is not simply a form of embellishment but a hermeneutical process with the potential to unfold new meanings. This notion of metaphor was shared by Murry himself. In an essay published in 1927 - the same year of the Journal's publication Murry defined metaphor as 'the instinctive and necessary act of the mind exploring reality and ordering experience', ${ }^{25}$ a kind of 'revelation' whereby 'something hitherto unknown is suddenly made known'. ${ }^{26}$ With these premises in mind, one can legitimately read the process of editing of the Journal as a fictional plot. According to Peter Brooks, a plot is 'the structure of action in closed and legible wholes; it thus uses metaphor as the trope of its achieved interrelations, and it must be metaphoric insofar as it is totalizing'. ${ }^{27}$ The 'achieved interrelations' that lead to a metaphoric meaning are best understood, however, in relation to another rhetorical figure - that of metonymy. As Brooks suggests, metonymy is what governs 'precedence and consequence, the movement from one detail to another, the movement towards totalization under the mandate of desire' ${ }^{28}$ This definition can also be employed to describe the process of rewriting enacted by Murry: the creation of a metaphoric, 'same-but-different' meaning (a 'same-but-different' Mansfield), which is in turn grounded on metonymic textual adjustment.

\footnotetext{
${ }^{25}$ John Middleton Murry, 'Metaphor', in Selected Criticism, 1916-1957 (Oxford: Oxford University Press, 1960), p. 65.

${ }^{26}$ John Middleton Murry, 'Metaphor', p. 67.

${ }^{27}$ Peter Brooks, Reading For the Plot: Design and Intention in Literature (Cambridge, Ma: Harvard University Press, 1992), p. 91.

${ }^{28}$ Peter Brooks, Reading For the Plot, p. 91.
} 
Let us turn then to two significant cases of Murry's 'editing for the plot'. In Chapter Two I have drawn attention to the workshop-nature of Mansfield's notebooks - the ways in which her jottings often move towards fiction. The notebook account of her 1912 trip to Gray, for instance, becomes the literary occasion for her 1915 story 'An Indiscreet Journey'. As I have pointed out, several elements of her diary entries are included in the fictional story, but Mansfield also decided to curtail explicit references to the relationship between the young woman travelling to the front and her lover, the 'little corporal'. This process of rewriting follows a sophisticated narrative strategy, where everything is at the same time told and untold.

Analogous processes of display and displacement - enacted for very different reasons and leading to a very different text - can be found in Murry's treatment of the same source text. The first journal entry (20 February) and part of the second entry (namely the paragraph containing the love scene with Carco) are cut out. The letter to Frieda Lawrence is introduced as 'An unposted letter written in the diary'; Frieda's name, which Mansfield mentions in the body of the letter, is replaced with the words 'my dear'. The recipient of the second 'unposted letter' was 'Jaggle' - a nom de plume for Murry. Like the more recurring 'Jack', Jaggle is disguised by the initial 'J.' (and other names of contemporaries mentioned in the Journal are dealt with in the same way). In the letter Mansfield tells Murry about the 'white house where he had taken a room for me'. As Kimber has observed, in his edited version 'Murry had written 'where they had taken a room for me' [...]. The use of "they" implies a much more 
impersonal, innocent reason for a journey and is much less difficult to explain than the word "he", with its attendant notion that Mansfield is a "femme seule"'. ${ }^{29}$ In other passages of Murry's version, the name of Francis Carco disappears under an unknown 'he'. Murry further censored the text by erasing any allusion to Mansfield's relationship with Carco: in addition to the 20 February entry and the 'love scene' in the second entry, he excised the ending of Frieda's letter (with the image of the 'petite soldat joyeux et jeune'), and other compromising details (Carco's loving words and the mention of the lovers' kiss in the cab). In the Journal Mansfield's reportage ends with the words 'It was like an elopement'. The simile appears in the manuscript as the amused remark of someone who was actually experiencing an elopement, but in the Journal the same words leave the reader rather puzzled. Why did Mansfield go to France? Who was the man she met at the front and what was the nature of their relationship? Not a single word is given by the editor to address these legitimate questions. The journey to Gray was like an elopement; but it was not, one is led to conclude.

The notebook material recounting the trip to Gray served two different narratives: the 1915 fictional narrative by Mansfield and the 1927 edited, censored, manipulated version of the same source text carried out by Murry. Indeed, two very different outcomes, springing from two different authorial intentions; and yet a

\footnotetext{
${ }^{29}$ Gerri Kimber, Katherine Mansfield: The View from France (Oxford: Peter Lang, 2008), p. 145.
} 
common ground can be traced in the process of rewriting itself, in the tension between display and displacement that both narratives enact.

Let us now consider a 1920 text, included in the Journal with the title 'Anguish'. The original text presents one of Mansfield's unsuccesful efforts to translate an autobiographical episode into literary forms of expression. The ebb and flow of life and fiction is marked by the interference of free direct speech (which betrays the voice of the author herself) and of personal allusions scattered into the fictitious text. The unresolved and rather confused plot of the story focuses on a distressed young woman who receives a letter from her lover. His words - 'don't give me up entirely' upset the woman deeply: 'He is killing me, killing me. He wants to be free - that's all' (KMN2, 200). Later on, the woman is at the post office, surrounded by 'horrible men who shouted over her shoulder', and then at the chemist's, where she purchases a dose of 'sal volatile'. Finally, she comes across Jinnie, a friend of hers, who takes her to the doctor. Doctor Rendall examines the 'highly sensitive' woman with great care and tells her to stay away from noise and 'repellent people'. The end of the story brings the reader back to the woman's miserable state: 'Oh anguish of Life! Oh bitter bitter life! He just threw her away - well 'don't give me up entirely' ... it was like Bavaria again but worse worse - \& now she could not take a drug - or anything. She must just bear it and go on' (KMN2, 201).

Murry correctly dated this text to 1920: he could easily do so because he recognized in the story a personal incident with his wife. The words 'don't give me up entirely' appear at the end of a letter Murry sent to Mansfield on 5 February 1920. At 
this time, Murry was working in London and his wife had just arrived in Menton, where she hoped to get better after the depressing time at 'La Casetta' in Ospedaletti, Italy. She needed money to pay for medical consultations and treatment, but the lack of sympathy from her husband tortured her. Misunderstandings develop from letter to letter, and eventually Mansfield vents her resentment:

You say I ought to have guessed you misunderstood. Curse money! Its not really a question of money. It was the question of sympathy, of understanding, of being in the least interested of asking JUST ONCE how I was - what I thought about $\&$ felt - what I did - if I was 'alright'? I cant get over the fact that it never occurred to you and it makes me feel you don't want my Love - not my living love - you only want an 'idea'. [ ...]

I cannot stand it any longer. You must tell me the truth. Here is your Thursday letter: 'Well Wig don't give me up entirely.' If you really contemplate the possibility of it then you no longer love me or believe in our marriage. You are simply killing me again and again with every letter. Your last, ASKING me to wire if I loved you! Now tell me at once, BY WIRE whether all is over or not. God! To have been driven by you to write such words. You cruel cruel - oh I am crying. Of course when I said I would not write again I only meant until I had your answer.

No you are too cruel. To throw away SUCH Love throw it away. Oh, you must have lied to me! I thought we could not live without each other. But now put me out of my pain. I cant bear it. I am in utter despair. I must know. ${ }^{30}$

The tone is very much that of the young woman in the fictional account. Moreover, the autobiographical background of the story can be seen in other details. The character of Jinnie comes through Jinnie Fullerton who, with Connie Beauchamp

\footnotetext{
${ }^{30}$ Katherine Mansfield, The Collected Letters of Katherine Mansfield, III, pp. 208-13.
} 
(Mansfield's cousin), would arrange Mansfield's move to Villa Flora, Menton. She does not like her current accommodation: 'this place is intolerably noisy. I am so sensitive to noise - oh - so sensitive. It hurts me really. They bang my door other doors shut shriek crash - I cant endure it \& really cant work or sleep'. ${ }^{31}$ Mansfield's sensitiveness to noise clearly echoes the 'highly sensitive' young woman's in the story. The name of the doctor, Rendall, is also borrowed from reality: before the move to Villa Flora, Jinnie Fullerton asked Doctor Rendal in Menton to examine Mansfield in order to obtain a certificate stating that her tuberculosis was no longer contagious.

In his version for the Journal Murry made several changes to the text. Here are the most significant:

\section{Katherine Mansfield Notebooks}

\section{1a)}

The letter. She read - she read to 'don't give me up entirely'. When she read those words it happened again - again there seemed to be a dreadful loud shaking \&trembling: her heart leaped, she sank down in the bed. She began to weep and could not stop. (KMN2, 200)

2a)

The waitress kept jerking her chair offering food. It was no good. She left \& went upstairs but that was fatal. Have I a home? A little cat? Am I any man's wife? Is it all over? He never tells me a thing - never a thing - just all those entirely self-absorbed letters and now just these notes. What will

\section{Journal of Katherine Mansfield}

1b)

The letter she read. And then it happened again, again there seemed to be a dreadful loud shaking \& trembling: her heart leaped, she sank down in the bed. She began to weep and could not stop. $(J, 145)$

2b)

The waiters kept jerking her chair, offering food. It was no good. She left and went upstairs, but that was fatal. Had she a home? A little cat? Was she any man's wife? Was it all over?

She dressed and went downstairs into the horrible hall, because there, with the monde

\footnotetext{
${ }^{31}$ Katherine Mansfield, The Collected Letters of Katherine Mansfield, III, p. 211.
} 
come next? He ask if I believe he loves me \& says 'don't give me up' but as though perfectly prepared for it. She wrote out the telegram He is killing me, killing me. He wants to be free - that's all.

She dressed \& went downstairs into the horrible hall because there with the monde drinking coffee \& cigarettes she dare not cry. (KMN2, 200)

3a)

And now - where? A dose of sal volatile at the chemist's. While he made it up \& down the shop twisting her hands. There was a box of Kolynos. It said Jack. Jack in her room, talking about the foam, saying he'd leave his behind. Four francs seventy-five. She bought and drank the mixture, \& now, where. $(K M N 2,200)$

\section{4a)}

Oh, if they could have known or seen my heart that had been stabbed \& stabbed. But she managed to smile \& thank the doctor \& then Jinnie put her back into the brougham $\&$ it was arranged she would leave in a week. (KMN2, 201)

\section{5a)}

Oh anguish of life! Oh bitter bitter Life! He just threw her away - well 'don't give me up entirely'. That reminded her of wallflowers \& Shakespeare. Yes, how in a Winter's Tale Perdita refused gillyflowers in her garden . (KMN2, 201) drinking coffee, she dared not cry. $(J, 146)$

$3 b)$

And now, where? A dose of sal volatile at the chemist's. While he made it up she walked quickly up and down the shop, twisting her hands. There was a box of Kolynos. It spoke of him, him in her room, talking about the foam, saying he'd leave his behind. Four francs seventy-five. She bought and drank the mixture, and now, where? $(J, 146)$

\section{4b)}

Oh, if they could have known or seen her heart that had been stabbed and stabbed. But she managed to smile and thank the doctor, and then Frances put her back into the brougham, and it was arranged she would leave in a week. $(J, 147)$

$5 b)$

Oh anguish of life! Oh, bitter, bitter Life. That reminded her of wallflowers and Shakespeare. Yes, how in a Winter's Tale Perdita refused gillyflowers in her garden. $(J, 147)$ 
Murry removed any allusion to the troubled relationship between him and his wife. His own voice - 'don't give me up entirely' - is suppressed in the edited version (see $1 \mathrm{a}$ and 5a). The name of Jack, which Mansfield uses in 3a, is replaced with an unproblematic personal pronoun. An intriguing change appears in 2a. Here the editor turns the free direct speech into a traditional third person narration. This shift not only makes the narrative more consistent from a formal point of view, but also testifies to Murry's endeavour to objectify Mansfield by 'repressing' the urgency of her free speech. The short-circuit between life and fiction is eventually overcome by the editor, who does what Mansfield, this time, is unable to achieve. Mansfield is displaced in favour of an 'idea of her'.

Narratives follow previous narratives and stretch towards future ones. Narrative is remembering - it ensures memory by containing an elusive meaning; however, 'the capacity to remember is also the capacity to elide or distort'. ${ }^{32}$ Narrative is intended to provide meaning but is also, at the same time, the most effective way of warping or controlling meaning. An example of this dual nature of narrative can be found in the most recent biography of Mansfield: Kathleen Jones' Katherine Mansfield: The StoryTeller. The cover blurb claims that this book 'gives a vivid portrayal of Mansfield correcting previous misinterpretations'. The readability of the book, however, is sometimes achieved at the expense of reliability. In the discussion of the Gray episode, for instance, Jones cites - without distinction - from Scott's edition of Mansfield's

\footnotetext{
${ }^{32}$ Cathy Caruth, Trauma, p. 153.
} 
Notebooks and from 'An Indiscreet Journey'. The fine line between the document and its fictional rewriting is once again blurred to the extent that, in the biographer's endnotes, a passage from 'An Indiscreet Journey' is incorrectly but tellingly ascribed to the Notebooks.

\section{Making the corpse meaningful}

In her insightful 1927 review of the Journal of Katherine Mansfield, Virginia Woolf highlighted a crucial aspect of the writer's jottings:

Nothing could be more fragmentary; nothing more private [...]. But then as the scraps accumulate we find ourselves giving them, or more probably receiving from Katherine Mansfield herself, a direction. From what point of view is she looking at life as she sits there, terribly sensitive, registering one after another such diverse impressions? She is a writer; a born writer. Everything she feels and hears and sees is not fragmentary and separate; it belongs together as writing. ${ }^{33}$

Woolf was not aware of the fact that another, invisible hand had shaped the writer's scraps into a book, translating, as it were, a confusing and fragmented material into a more coherent narrative - a narrative with a 'direction'. Nonetheless, the tension between fragment and wholeness, in Murry's editing process, also seems to me to intersect some profound tensions underlying Mansfield's writing and life. Murry's process of rewriting bears witness to that sense of fragmentation and disunity that Mansfield always tried to resolve as a woman and as a writer.

\footnotetext{
${ }^{33}$ Virginia Woolf, 'A terribly Sensitive Mind', in The Critical Response to Katherine Mansfield, p. 16.
} 
Scholars have often drawn attention to Mansfield's complex notion of self: a self conceived as multiple and fragmented but driving towards unity and completion. In a well-known passage from a 1920 notebook, Mansfield expresses her idea of selfhood in the following terms:

True to oneself! Which self? Which of my many - well, really, that's what it looks like coming to - hundreds of selves? For what with complexes and repressions and reactions and vibrations and reflections, there are moments when I feel I am nothing but the small clerk of some hotel without a proprietor, who has all his work cut out to enter the names and hand the keys to the wilful guest.

Nevertheless, there are signs that we are intent as never before on trying to puzzle out, to live by, our own particular self. Der Mensch muss frei sein - free, disentangled, single. Is it not possible that the rage for confession, autobiography, especially for memories of earliest childhood, is explained by our persistent yet mysterious belief in a self which is continuous and permanent; which, untouched by all we acquire and all we shed, pushes a green spear through the dead leaves and through the mould, thrusts a scaled bud through years of darkness, until, one day, the light discovers it and shakes the flower free - and we are alive - we are flowering for our moment upon the earth? This is the moment which, after all, we live for, the moment of direct feeling when we are most ourselves and least personal. $(K M N 2,204)$

The Journal - with its collection of 'false starts' always on the verge of becoming literature and always hanging back from it - is the formal exemplification of a fragmented identity striving for unity and cohesion.

Mansfield's fragmented identity reflects in turn the sense of fragmentation of an entire age - that traumatic Georgian period captured by Virginia Woolf in $M r$. Bennett and Mrs. Brown: 
[O]n or about December 1910 human character changed. [...] All human relations have shifted - those between masters and servants, husbands and wives, parents and children. And when human relations change there is at the same time a change in religion, conduct, politics, and literature. [...] And so the smashing and the crashing began. Thus it is that we hear all round us, in poems and novels and biographies, even in newspaper articles and essays, the sound of breaking and falling, crashing and destruction. It is the prevailing sound of the Georgian age. [...] Signs of this are everywhere apparent. Grammar is violated; syntax disintegrated. ${ }^{34}$

The sound of 'breaking and falling, crashing and destruction' was particularly violent during the years of the Great War, which 'irrevocably shattered any remaining hope in the old certainties about faith, history and knowledge' ${ }^{35}$ In the midst of this collective turmoil, Mansfield suffered a personal loss when her brother, Leslie Beauchamp, was accidentally killed while serving at the French front. In Chapter Two I have discussed the significance of this episode in the light of Mansfield's literary rewriting. Here I would like to re-consider it from a different angle: what impact did this episode have on Mansfield's identity? And did it have any repercussions on Murry's editorial rewriting?

There is something puzzling about Mansfield's evocation of Leslie in the Journal. As Darrohn has noted, 'despite the boundary of death, any separation between Mansfield

\footnotetext{
${ }^{34}$ Virginia Woolf, Mr. Bennett and Mrs. Brown (London: Hogarth Press, 1924), pp. 4, 20 and 21.

${ }^{35}$ Mary Ann Gillies and Aurelea Mahood, Modernist Literature: An Introduction (Edinburgh: Edinburgh University Press, 2007), p. 9.
} 
and her brother is gradually dissolved'. ${ }^{36}$ Evidence of this physical and spiritual identification with her dead brother appears in several passages of the Journal:

I think I have known for a long time that life was over for me, but I never realized it or acknowledged it until my brother died. Yet, though he is lying in the middle of a little wood in France ... I am just as much dead as he is. $(J, 36)$

I felt my face was his serious, sleepy face. I felt that the lines of my mouth were changed, and I blinked like he did on waking. $(J, 44)$

Each time that I take up my pen you are with me. You are mine. You are my playfellow, my brother, and we shall range all over the country together. It is with you that I see, and that is why I see so clearly. $(J, 46)$

In every word I write and every place I visit I carry you with me. Indeed that might be the motto of my book. $(J, 46)$

Now I will come quite close to you, take your hand, and we shall tell this story to each other. $(J, 47)$

Mansfield's identification with her dead brother seems to suggest an almost pathological desire. But this identification is also associated with the act of writing itself: 'Each time that I take up my pen you are with me ... It is with you that I see ... In every word I write and every place I visit I carry you with me'. The identification with Leslie reflects Mansfield's creative need to become the object of her own observation: a need that is central to her method as a writer, as the following passage from a 1917 letter to Dorothy Brett illustrates:

\footnotetext{
${ }^{36}$ Christine Darrohn, 'Blown to Bits!', p. 517.
} 
What can one do, faced with this wonderful tumble of round bright fruits, but gather them and play with them-and become them, as it were. When I pass the apple stalls I cannot help stopping and staring until I feel that I, myself, am changing into an apple, too-and that at any moment I may produce an apple, miraculously, out of my own being like the conjurer produces the egg. When you paint apples do you feel that your breasts and your knees become apples, too? Or do you think this is the greatest nonsense. I don't. I am sure it is not. When I write about ducks I swear that I am a white duck with a round eye, floating in a pond fringed with yellow blobs and taking an occasional dart at the other duck with the round eye, which floats upside down beneath me. ${ }^{37}$

This passage and those where Mansfield identifies herself with Leslie, read together, prompt the question: What does it mean, for Mansfield, to become her brother?

The representation of Leslie in Mansfield's notebooks is unsettling. As we saw in Chapter Two, a few weeks after his death, for example, she wrote:

But then, when I leaned out of the window I seem to see my brother dotted all over the field - now on his back, now on his face, now huddled up, now half-pressed into the earth. Wherever I looked, there he lay, I felt that God showed him to me like that for some express purpose, and I knelt down by bed. But I could not pray. I have done no work. (J, 44)

As I argued in Chapter Two, the freeze-frame sequence of Leslie 'dotted all over the field' is one of crude realism: his body was 'blown to bits' in a hand grenade explosion. This image returns to haunt Mansfield in its brutal and non-symbolic inexplicability. Indeed, the 'express purpose' of the scene recorded by Mansfield is missing: she can neither pray nor work. In 1916 Mansfield wrote a poem in memory of her brother that, once again, points to the fragmented, 'plural' nature of his body:

\footnotetext{
${ }^{37}$ Katherine Mansfield, Collected Letters of Katherine Mansfield, II, p. 330.
} 
Last night for the first time since you were dead

I walked with you, my brother, in a dream.

We were at home again beside the stream

Fringed with tall berry bushes, white and red.

'Don't touch them: they are poisonous,' I said.

But your hand hovered, and I saw a beam

Of strange, bright laughter flying round your head

And as you stooped I saw the berries gleam -

'Don't you remember? We called them Dead Man's Bread!'

I woke and heard the wind moan and the roar

Of the dark water tumbling on the shore.

Where - where is the path of my dream for my eager feet?

By the remembered stream my brother stands

Waiting for me with berries in his hands ...

'These are my body. Sister, take and eat.' (KMN2, 29)

Scholars have underlined the religious undertones of the poem and in particular of the last line, with its allusion to the Gospel account of the Last Supper. However, they have overlooked the poignant, denotative meaning of that plural demonstrative: 'These are my body'. The Brother offers the remnants of his body to his sister. The appropriation of Leslie's body - orally incorporated by the sister - is the appropriation of a broken body; an appropriation that takes the form of a physical and spiritual identification with it: 'We were almost like one child' Mansfield declares in another passage of the Journal (34).

In 1919, three years later, Mansfield wakes up from another disturbing dream. This time, the reconstruction of the dream is not given in the enigmatic form of a poem, but through the immediacy of a diary entry: 
I must put down here a dream. The first night I was in bed here, i.e. after my first day in bed, I went to sleep. And suddenly I felt my whole body breaking up. It broke up with a violent shock-an earthquake-and it broke like glass. A long terrible shiver, you understand-the spinal cord and the bones and every bit and particle quaking. It sounded in my ears a low, confused din, and there was a sense of floating greenish brilliance, like broken glass. $(J, 132)$

Mansfield describes her body as 'blown to bits', a body which explodes in all directions like a shell. This text is not a conscious recollection of Leslie's death; rather, it is a re-enactment, a repetition of that haunting image. In a 1914 essay, Sigmund Freud made a crucial distinction between remembering and repetition, arguing that 'the patient does not remember anything of what he has forgotten or repressed, but acts it out. He reproduces it not as a memory but as an action; he repeats it, without, of course, knowing that he is repeating it'. ${ }^{38}$ The 'violent earthquake' shaking Mansfield's spirit and body re-enacts the violent death of her brother.

The account of the dream continues with the description of Mansfield's waking up:

When I woke I thought that there had been a violent earthquake. But all was still. It slowly dawned upon me-the conviction that in that dream I died. I shall go on living now-it may be for months, or for weeks or days or hours. Time is not. In that dream I died. The spirit that is the enemy of death and quakes so and is so tenacious was shaken out of me. I am (December 15, 1919) a dead woman, and I don't care. It might comfort others to know that one gives up caring; but they'd not believe any more than I did until it happened. And, oh, how strong was its hold upon me! How I adored life and dreaded death! $(J, 132)$

\footnotetext{
${ }^{38}$ Sigmund Freud, 'Remembering, Repeating and Working-Through', in The Standard Edition of Complete Psychological Works of Sigmund Freud, trans. by James Strachey, Vol. 12, p. 150 (Italic in the text).
} 
These words are reminiscent of what Mansfield wrote in the aftermath of Leslie's death, in the diary entry where she described herself 'as much dead as he is' $(J, 36)$. On that occasion, however, Mansfield decided to challenge death in the name of literature: 'Then why don't I commit suicide? Because I feel I have a duty to perform to the lovely time when we were both alive. I want to write about it, and he wants me to' $(J, 37)$. In another passage Mansfield had also written: 'I want to write down the fact that not only am I not afraid of death - I welcome the idea of death. I believe in immortality because he is not here, and I long to join him. First, my darling, I've got things to do for both of us, and then I will come as quickly as I can' $(J, 35)$.

The similarity between these excerpts and the 1919 one is compelling. In 1919 Mansfield describes herself, again, as a dead woman; she does so by waking up from a dream where the traumatic death of her brother is again repeated. But if death, in 1915 , is suspended on the imperative of a literary project, four years later it comes across as accepted - a part of life itself. What does it mean, for Mansfield, to be 'a dead woman' and still to be alive? What does it mean to wake up beyond death?

Mansfield's approach to death cannot be fully grasped without considering another crucial event: in 1917, she was diagnosed with pulmonary tuberculosis. Confronted with the likely prospect of death, Mansfield launched herself on a restless quest for health. Death was something to be delayed as much as possible in order to pay her 'sacred debt': 'How unbearable it would be to die - leave "scraps", "bits" ... nothing real finished' $(J, 75)$. However, a closer examination of her writing also reveals an 
opposite impulse: an irreversible movement towards death - something that can be legitimately described in the Freudian terms of a death drive.

This drive is manifest in the dream account quoted above. It can also be seen, more subtly, in the way in which Mansfield relates to her work. To write means to act, to endure, to survive, to postpone the encounter with death. At the same time, to bring something to an end - to 'finish' it - also means to let it go, to let it die. This paradox is well illustrated in the Journal, which documents Mansfield's detours as a writer and as a woman and her longing for a meaningful completion. In Mansfield's own words: 'There is no feeling compared with the feeling of having written and finished a story' (J, 214); 'My deepest desire is to be a writer, to have a "body of work" done' $(J, 196)$; 'I really only ask for time to write it all - time to write my books. Then I don't mind dying. I live to write' $(J, 102)$. The metaphoric expressions used by Mansfield reveal a connection between writing and dying. To have a 'body of work done' implies the death of the physical body: to die means to assemble a dismembered body - a body of 'bits' and 'scraps' - into a coherent whole, a single unified subject. The identification with Leslie Beauchamp is not only the identification with a broken body but also, ultimately, with death itself: with what makes that body meaningful.

In Chapter Two I have argued that the identification of Leslie's body with the dead carter in 'The Garden Party' served Mansfield's need to rewrite her traumatic loss. In a 1922 letter to William Gerhardi, Mansfield wrote:

And yes, this is what I tried to convey in The Garden Party. The diversity of life and how we try to fit in everything, Death included. That is 
bewildering for a person Laura's age. She feels things ought to happen differently. First one and then another. But life isn't like that. We haven't the ordering of it. Laura says 'But all these things must not happen at once' and Life answer 'Why not?' How are they divided from each other.' And they do all happen, it is inevitable. And it seems to me that there is beauty in that inevitability. ${ }^{39}$

To integrate death into life means to make it narratable and therefore meaningful. 'Death is the sanction of everything that the storyteller can tell' as Walter Benjamin observes. ${ }^{40}$ 'It is at the moment of death', Peter Brooks explains, 'that life becomes transmissible' ${ }^{41}$

It is to me significant, and moving, that the last words in Mansfield's 'happy ending' - the 'fitting close' of her Journal - read as follows:

And this all sounds very strenuous and serious. But now that I have wrestled with it, it's no longer so. I feel happy - deep down. All is well. (J, 151)

The phrase 'All is well' - italicised in the book and underlined in the manuscript - is in fact a quotation: it appears in another dream account about Leslie Beauchamp and in the scene of the dead carter in 'The Garden Party':

He puts his arm round me, holding me tightly, and we kiss - a long, firm, family kiss. And the kiss means: We are of the same blood; we have

\footnotetext{
${ }^{39}$ Katherine Mansfield, Collected Letters of Katherine Mansfield, V, p. 101.

${ }^{40}$ Walter Benjamin, 'The Storyteller', in Illuminations, trans. by Harry Zohn (New York: Schochen Books, 1969), p. 94.

${ }^{41}$ Peter Brooks, Reading for the Plot: Design and Intention in Narrative (London and Cambridge, MA: Harvard University Press, 1992), p. 28.
} 
absolute confidence in each other; we love; all is well; nothing can ever come between us ( $J, 106-107$, my emphasis)

While they were laughing and while the band was playing, this marvel had come to the lane. Happy... happy... All is well, said the sleeping face. This is just as it should be. I am content. (CF2, 261, my emphasis)

The bits and scraps of the Journal, the detours of Mansfield's diary jottings, the arabesque of her life, find a resolution - inevitable and beautiful - in this happy ending; in this special moment, when the protagonist of the Journal seems to have found her 'true self; when Katherine Mansfield is finally 'most herself and least personal'.

The Journal of Katherine Mansfield, I have argued, is the record of a visible, meaningful life and the record of its invisible appropriation. John Middleton Murry amputated and trimmed Mansfield's notebooks; he manipulated and censored the text; he 'translated' it into a single narrative. This invisible process of appropriation and displacement, however, shows the desire for meaning embedded not only in Mansfield's writing and life but in any process of rewriting. To unveil the rewriting of a text or a life - in other words, to witness its 'afterlife' - is always an attempt to reveal the paradox of memory, its unreliability: what has been preserved and retained is also what has been lost or suppressed. 


\title{
Chapter Four
}

\section{Translating Mansfield}

\begin{abstract}
What we most fear $[\ldots]$ is not death; nor even physical anguish, mental decay, disintegration. We fear most the loss of meaning. To lose meaning is to lose one's humanity, and this is more terrifying than death.
\end{abstract}

JOYCE CAROL OATES

Never mind my soul, Tuohy. Just make sure you get my tie right.

JAMES JOYCE (to his portrait painter Patrick Tuhoy)

\section{Trauma and Translation}

In the early nineteenth century, Schleiermacher noted that 'understanding is an unending task' and 'the talent for misunderstanding is infinite'. ${ }^{1}$ In more recent times, meaning has been understood as an endless deferral: the more one tries to grasp it, the more it appears ungraspable. This rings especially true when we consider the particular form of understanding that is translation. Since the meaning of a text is closely attached to its 'letter' - its sound or signifier - translation can never be a simple transfer of meaning. Indeed, no matter how accurately one brings meaning

\footnotetext{
${ }^{1}$ Quoted in Routledge Encyclopedia of Translation Studies, ed. by Mona Baker and Gabriela Saldanha (London and New York: Routledge, 2009), p. 131.
} 
'home', ${ }^{2}$ the result is inevitably approximate, partial - a fraught compromise reached through negotiation and compensation.

If meaning is constantly deferred and displaced, however, what kind of 'testimony' can translation truly offer? In other words, how can translation bear witness to its reference - the source text?

A possible answer can be sought by looking again at that paradoxical form of witnessing that is trauma. In Chapter Two I have illustrated the structure of the traumatic experience through Freud's well-known case of the fort/da game. Freud describes, as we recall, the game of his little grandson, who throws a wooden spool away uttering 'o' (fort, 'gone') and then retrieves it uttering 'da' ('here'). A closer examination of the boy's game allowed Freud to suggest that the repetitive fort reenacts, compulsively, what the boy cannot fully understand: the traumatic experience of being abandoned by his mother.

The enigmatic nature of the traumatic experience can also be read in translational terms. 'Translation', writes Susan Bassnett, 'may be a means of recovering the past, of bringing the dead back to life, but what it recovers must remain forever incompletely known and understood'. ${ }^{3}$ In the fort/da game the meaning of the traumatic event is constantly deferred and therefore compulsively repeated. Even Freud's actual translation of the boy's sounds into German - a coded

\footnotetext{
2 'The translator invades, extracts, and brings home'. George Steiner, After Babel: Aspects of Language and Translation (Oxford: Oxford University Press, 1992), p. 314.

${ }^{3}$ Susan Bassnett, 'Prologue', in Tradition, Translation, Trauma: The Classic and the Modern, ed. by Jan Parker and Timothy Mathews (Oxford: Oxford University Press, 2011), p. 2.
} 
language - is less straightforward than it might appear: the analyst moves from one interpretation to the other (the game is now a game about departure, now about departure and return, and then again about departure) almost suggesting a reenactment of the game structure in his own theoretical speculation. ${ }^{4}$

A translation, like trauma, can never be considered as definitive or exhaustive. This is why a text can be re-translated an infinite number of times. Re-translation is always 'stimulated', Paul Ricoeur argues, 'by the dissatisfaction with regard to existing translations ${ }^{5}{ }^{5}$ A new translation may bring the promise of a better and firmer grasp on the source text; nonetheless, this is possible only within certain limits: ultimately both theoretically and practically - one has to 'give up the ideal of perfect translation'. ${ }^{6}$ To give up is to acknowledge the incommensurable difference between the source text and the translated one and to accept the impossibility of fully capturing and recapturing meaning. Translation thus characterizes itself as a utopian enterprise - 'a living utopia' in the words of José Ortega y Gasset.?

A closer look at Freud's text, however, suggests a somewhat different understanding of trauma and translation. The repetition compulsion testifies to what is not yet understood; it points, in other words, to a meaning that does not only

\footnotetext{
${ }^{4}$ Cf. Cathy Caruth, Literature in the Ashes of History (Baltimore: The Johns Hopkins University Press, 2013), p. 15.

${ }^{5}$ Paul Ricoeur, 'Translation as Challenge and Source of Happiness', in On Translation, trans. by Eileen Brennan (New York: Routledge, 2006), p. 7.

${ }^{6}$ Paul Ricoeur, p. 8.

${ }^{7}$ José Ortega y Gasset, 'The Misery and the Splendor of Translation', in Theories of Translation: An Anthology of Essays from Dryden to Derrida, ed. by Rainer Schulte and John Biguenet, trans. by Elizabeth Gamble Miller (Chicago: University of Chicago Press, 1992), p. 94.
} 
belong to the past but also, and enigmatically, to the future. Significantly, in the fort/da game, the encounter with an ungraspable meaning turns into something new: the repetition of a creative act. Indeed, Freud emphasizes that the fort/da game was the 'first self invented game' of the boy, an observation that Jacques Lacan and then Cathy Caruth later adopted and developed. The game 'represents the origin of symbolic language as such in the differentiation of the phonemes o and a'. ${ }^{8}$ Freud's example also recalls Derrida's image of translation as a child who is not simply 'a product subjected to the law of reproduction' but 'has the power to speak on its own'. With his game the boy bears witness to the inexplicable otherness of his past; yet, in returning to this enigmatic past, the boy simultaneously departs into the future of his own existence. Walter Benjamin maintained that translation ensures the survival of a text, offering its potential for an 'afterlife'. ${ }^{10}$ Translation, like trauma, is its survival, its future: 'the waking up in another fright'.

This double nature of translation is palpable in what Antoine Berman calls the labor on the letter. 'Labor on the letter in translation is more originary than restitution of meaning. It is through this labor that translation, on the one hand, restores the particular signifying process of works (which is more than their meaning) and, on the

\footnotetext{
${ }^{8}$ Cathy Caruth, Literature in the Ashes of History, p. 94.

9 Jacques Derrida, 'Des tours des Babel', in Difference and Translation, ed. by Joseph F. Graham (Ithaca: Cornell University Press, 1985), p. 191.

${ }^{10}$ Cf. Walter Benjamin, 'The Task of the Translator: An Introduction to the Translation of Baudelaire's Tableaux Parisiens', The Translation Studies Reader, ed. by Lawrence Venuti, trans. by Harry Zohn (New York: Routledge, 2004), pp. 75-85.
} 
other hand, transforms the translating language'. ${ }^{11}$ Since the letter is the 'body' in which meaning finds its full realization, an attention to the letter is also an indirect way to get access and bear witness to the text's profound signification. A translation of the letter is not to be confused with a literalist or word-for-word translation. To labor upon the letter means to pay attention to the unique tone of the source text, to its dominant figures of sound, to the meaningful pauses of punctuation, to the pitch of the characters' voice, to their silences, to the sonorous, material and iconic richness of words, to their echoes, to the rhythmic flow of the text. Then, the labor upon the letter involves the ability of bringing such elements over into another language, in a way that is comparable with the intention and the emotional drive of the source text.

This is not, of course, an easy task. It requires a lot of time and patience, in an effort to eschew those 'largely unconscious' deforming tendencies that, according to Berman, prevent the ethical aim of translation: accepting the Foreign as Foreign. These tendencies are: 1) Rationalization (the rearrangement of textual order); 2) Clarification (the explication of what, in the source text, is concealed or repressed); 3) Expansion (the textual unfolding and stretching); 4) Ennoblement and popularization (a process of rewriting that produces elegant and readable texts or, conversely, that blindly recurs to a pseudo-slang); 5) Qualitative impoverishment (the impoverishment of the sonorous and iconic richness of text); 6) Quantitative impoverishment (the loss of lexical variation); 7) The destruction of rhythms (the modification or annihilation of

\footnotetext{
${ }^{11}$ Antoine Berman, 'Translation and the Trials of the Foreign', in The Translation Studies Reader, trans. by Lawrence Venuti, pp. 288-9.
} 
the textual rhythmic flow); 8) The destruction of underlying networks of signification (the erasure of sub/inter-textual references); 9) The destruction of linguistic patternings (the eradication of the author's more frequent linguistic constructions); 10) The destruction of vernacular networks or their exoticization (the elimination of vernacular expressions); 11) The destruction of expressions and idioms (especially in the effort of finding supposed equivalents); and 12) The effacement of superimposition of languages (the effacement of the linguistic variety or heteroglossia).

Some of these tendencies are the direct consequence of others (for example, the destruction of rhythm derives from textual rationalization or expansion). In order to explain how these tendencies impinge upon the translating text, I will now offer some close readings from the first Italian translation of the 1927 Journal.

\section{Diario di Katherine Mansfield}

Diario di Katherine Mansfield was published in 1933 by Corbaccio editore. ${ }^{12}$ Like many early twentieth-century Italian translations, it reads rather 'sloppily' and would have required a substantial editorial revision. Some errors - for example the literal translation of phrasal verbs - are due to the translator's clearly poor knowledge of English; but although this is often the case, I would rather highlight what the translator deliberately 'overinterpreted' in her effort to bring meaning over into

\footnotetext{
${ }^{12}$ Katherine Mansfield, Diario di Katherine Mansfield, trans. by Mara Fabietti (Milano: Corbaccio, 1933). Further references are cited parenthetically as $D$ with the page number.
} 
Italian. It is precisely on the grounds of over-interpretation that deforming tendencies virally proliferate.

The number of pages of the translation is the first clear sign of Fabietti's disposition to expansion: 295 dense pages in the Italian edition; 250 airy ones in the original. Expansion is in turn an effect of rationalization or clarification, as the following excerpts illustrate:

Journal of Katherine Mansfield
la
We sat in a bus talking, and now and again
when I looked up, I kept seeing the squares
with their butterfly leaves just ready to fly.
$(J, 10)$
2a
My mind is full of embroidery. ( $J, 13)$
3a
The red geraniums have bought the garden
over my head. (J, 105)
4a
The charwomen, blown old flies, buzz
down each other's basements... ( $J$, 79)

$5 a$

The fire makes a noise like a flag. $(J, 97)$

\section{Diario di Katherine Mansfield}

$1 b$

Parlavamo, sedute in autobus, e di quando in quando, osservando fuori, vagavo con lo sguardo su piazze in cui le foglie degli alberi si libravano come farfalle pronte a spiccare il volo. $(D, 26)$

$2 \mathrm{~b}$

Ho la mente piena di sogni vaghi come ricami. $(D, 31)$

$3 b$

I rossi gerani hanno invaso tutto il giardino. $(D, 130)$

$4 \mathrm{~b}$

Le donne di servizio ad ore, vecchie mosche affaticate, vanno ronzando da un pianterreno all'altro, raccontandosi gli avvenimenti della giornata... $(D, 103)$

$5 b$

Il fuoco fa un rumore come di bandiera che sventoli. $(D, 122)$ 
$6 a$

Wasted! Wasted! $(J, 20)$

$11 \mathrm{a}$

No new places-no new things. $(J, 108)$

$9 \mathrm{a}$

There goes the gong. $(J, 83)$

$10 \mathrm{a}$

Young girls make me feel forty. $(J, 151)$

$7 \mathrm{a}$

the baby boy, bursting out of an English tweed suit that was intended for a Norfolk. $(J, 30)$

$8 \mathrm{a}$

the coldness, the blueness of the children. $(J, 154)$

$12 \mathrm{a}$

'Send Ralph, please.' Ralph arrives. I arrange the food. Then settle all that must be done, coercing Ralph, putting her mind in order if I can, making her see the bright side of things, sending her away (I hope) feeling important and happy. $(J, 109)$
$6 \mathrm{~b}$

Ho sprecato, ho sciupato il mio tempo anche oggi! $(D, 38)$

$11 b$

Non amo i cambiamenti di luogo e di cose. $(D, 133)$

$9 b$

Ecco il gong che annuncia il pranzo. ( $D$, 108)

$10 \mathrm{~b}$

Ho l'impressione di avere quarant'anni quando contemplo delle giovinette. $(D, 180)$

$7 \mathrm{~b}$

Un maschietto ormai cresciuto per stare nel suo misero vestitino di lana inglese. $(D, 50)$

$8 \mathrm{~b}$

I fanciulli violacei per il freddo. $(D, 183)$

$12 \mathrm{~b}$

Feci chiamare Ralph e con lei disposi per il pranzo e per tutto il resto ammonendola di essere ordinata, presentandole ogni cosa dal suo lato simpatico, congedandola infine soddisfatta e felice. $(D, 133)$

One of the ways in which clarification exerts its deforming force on the source text is by explicating tropes. Fabietti often turns metaphors into similes (see $1 \mathrm{~b}$ and $2 \mathrm{~b}$ ), revealing an analytic approach that goes against the grain of the essentially metaphoric, synthetic drive of Mansfield's prose. Fabietti clarifies Mansfield's 
idiomatic sentence in $3 \mathrm{a}$, and unfolds the charwomen/fly image in $4 \mathrm{a}$. In $5 \mathrm{~b}$, to Mansfield's simile corresponds to Fabietti's extended rendering, with an addition that, with Berman, 'adds nothing,. ${ }^{13}$ The examples from 6 to 10 are further cases of expansion and clarification. The casual swiftness of Mansfield's diary style is lost in the translator's effort to explain everything. Examples 7 and 8 reveal the translator's intention to explicate a cause that in the English text is kept undisclosed. Fabietti tells as much as Mansfield shows. This preference for telling over showing is most palpable in 10b, where Fabietti thoroughly rewrites Mansfield's scene, changing direct speech into indirect speech and present tense into past tense. The Italian version reads more coherent than the English one - Mansfield's text will subsequently and brusquely switch to the past tense - but the 'sketchy', workshoplike nature of the notebook is lost.

In other passages the translator 'ennobles' Mansfield's text by enhancing, for example, its spiritual overtones. Let us have a look at these examples:

$13 \mathrm{a}$

Part of my breathing. $(J, 54)$

$14 \mathrm{a}$

To be alone all day, in a house whose every sound seems foreign to you, and to feel a terrible confusion in your body which affects you mentally. $(J, 1)$

$15 \mathrm{a}$

I feel so full of love to-day after having seen the sun rise. $(J, 19)$
$13 b$

Parte della mia vita spirituale. $(D, 76)$

$14 \mathrm{~b}$

Essere sola tutto il giorno in una casa in cui ogni suono vi sembra estraneo, sentire nel vostro corpo un terribile sbalordimento, il quale attacca anche il vostro spirito. $(D, 17)$

$15 b$

Oggi, dopo aver visto il levar del sole mi sento in cuore come un'estasi d'amore. $(D, 38)$

\footnotetext{
${ }^{13}$ Antoine Berman, 'Translation and the Trials of the Foreign', p. 282.
} 
$16 \mathrm{a}$

We were almost like one child. $(J, 34)$

$17 \mathrm{a}$

At the back of my mind I am so wretched. $(J, 143)$

$18 \mathrm{a}$

It slowly dawned upon me-the conviction that in that dream I died. ( $J$, 132)
$16 \mathrm{~b}$

Eravamo come un'anima sola. $(D, 54)$

$17 \mathrm{~b}$

Una macchia così odiosa nel mio spirito! $(D, 191)$

$18 \mathrm{~b}$

Lentamente, cominciò a sorgere dentro il mio spirito la certezza di essere morta durante il sogno. $(D, 158)$

These excerpts illustrate how Fabietti continues the process of purification that Murry's editing had begun, enhancing the portrait of the sentimentalized author.

Mansfield often inserts French expressions into her text with a sort of tonguein-cheek humour. Fabietti most of the time blends the French into Italian, effacing the superimposition of languages and the witty timbre of Mansfield's voice. What in the English version is expressed with irony comes out rather dull in the target text:

$19 \mathrm{a}$

Je me sens incapable de tout. $(J, 18)$

$20 \mathrm{a}$

Jai envie de prier au bon Dieu comme le vieux pére Tolstoi. Oh, Lord, make me a better creature to-morrow. Le coeur me monte aux lévres d'un goût de sang. Je me deteste aujourd'hui. $(J, 18)$

$21 \mathrm{a}$

The waitress hovered round the table, delighted beyond words at this exhibition of vie de famille. $(J, 31)$
$19 \mathrm{~b}$

Non mi sento capace di nulla. $(D, 36)$

20b

Ho voglia di pregare il Signore come il vecchio papà Tolstoi. Oh! Dio, fatemi esser migliore, domani. Mi sento il cuore in bocca con sapor di sangue. Oggi odio me stessa. $(D, 36)$

$21 b$

La cameriera si aggirava intorno alla tavola, con inesprimibile ammirazione dinanzi a quel dolce spettacolo familiare. $(D, 51)$ 
$22 \mathrm{a}$

There's not a leaf in France that you can't 'faire une infusion avec,' not a blade that isn't 'bon pour la cuisine.' $(J, 60)$

$23 \mathrm{a}$

but living as I do in a public house-it's trés difficile. $(J, 86)$

$24 \mathrm{a}$

I decided to faire les ongles de mes pieds avant mon petit déjeuner - and did not from idleness. $(J, 86)$
$22 b$

In Francia, tutte le foglie possono servire a fare un decotto, e qualunque rimasuglio può essere utile in cucina. $(D, 82)$

$23 \mathrm{~b}$

$\mathrm{Ma}$ vivere come me, in un albergo... è molto, molto difficile. $(D, 111)$

$24 \mathrm{~b}$

Ho deciso di mettermi in ordine le unghie dei piedi prima del caffelatte, e non l'ho fatto per pigrizia. $(D, 111)$

These examples also reveal an ethnocentric approach to translation that is particularly evident in the rendering of food. In 12, petit déjeneur is translated with caffelatte ('milk and coffee' - the typical Italian breakfast); in other passages, Fabietti translates 'bacon' with prosciutto, 'scones' with torte, 'onion sauce' with contorno di cipolle, 'consommé' with brodo ristretto, and 'sago' with minestrina di farina di patate. The names of people are Italianized, according to the translating conventions of the time: Dorotea Wordsworth for Dorothy Wordsworth, Giovanna Austen for Jane Austen, and of course Caterina Mansfield for Katherine Mansfield (on the front page, however, the English spelling is retained).

Rationalization, clarification and extension have a huge impact on rhythm, one of the best qualities of Mansfield's prose, which can be appreciated even in some of her diary jottings. Consider these examples: 
$25 \mathrm{a}$

The sky is filled with the sun, and the sun is like music. The sky is full of music. $(J, 110)$

$26 \mathrm{a}$

One is flung up-out of life-one is 'held', and then,--down, bright, broken, glittering on to the rocks, tossed back, part of the ebb and flow. [...] but while one hangs, suspended in the air, held,-while I watched the spray, I was conscious for life of the white sky with a web of torn grey over it; of the slipping, sliding, slithering sea; of the dark woods blotted against the cape; of the flowers on the tree I was passing; and more. $(J, 148)$
$25 b$

Il cielo è inondato di musica: essa scende a noi portata dai raggi. $(D, 135)$

$26 \mathrm{~b}$

Ci si sente proiettati fuori dell'esistenza... e poi ripresi, e allora si ricade giù, frantumandoci in mille pezzi scintillanti sulle rocce, fino a che il risucchio ci riafferra via nel mare. [...] mentre osservavo gli spruzzi schiumosi, ebbi coscienza, per tutta la vita, di quel cielo bianco velato da una bruma grigiastra stracciata qua e là: del mare sfuggente, inafferrabile: dei boschi neri, che risaltano come macchie contro il promontorio; dell'albero fiorito, sotto il quale passavo, e d'altre cose ancora... ( $D$, 176)

In 1, the almost haiku-like rhythm of Mansfield's sentence is rearranged in a plain, loose form; the punctuation is rationalized and the strength of a poetic syllogism is diluted into a sentimental observation. In 2, Mansfield's fast, disrupted rhythm is one with the image she describes - the atemporal suspension of the wave before its sudden fragmentation; Fabietti does not make any effort to preserve the stark sense of fragmentation suggested by the author; on the contrary, she is chiefly concerned to assemble Mansfield's jagged prose, reorganizing its temporal structure: e poi... allora... fino a che. Like Murry's editing, Fabietti's translation seems to be driven, consciously or otherwise, by a desire for connectedness and wholeness - an attempt to unify the divided identity of the author. And no particular attention is paid to the sonorous richness of Mansfield's description, to the alliterations ('slipping, sliding, 
slithering sea'), to the surprising iconic richness of the images described (the 'web of torn grey' is explained - and banalized - as 'bruma grigiastra stracciata qua e là').

On the level of punctuation - an aspect that Mansfield considered infernally difficult'14 - the translator's choices are equally sentimental as those of the editor's. Consider the rendering of this passage:

$27 \mathrm{a}$

But once fed with my suit-case and our two selves, it dashed off like the wind, the door opening and shutting, to his horror, as he is not allowed in cabs.

$(J, 25)$
$27 b$

Appena caricata la mia valigia e saliti noi stessi nel veicolo, esso si mosse come il vento; la portiera s'apriva e si chiudeva con grande ansia di lui, perché non aveva il permesso di viaggiare in carrozza. $(D, 44)$

In 1 , the translator replaced the comma with the semicolon, restraining the flow of the text, which is further weighted down by the switch from the present tense in the English text ('he is not allowed') to the past tense in the Italian version ('non aveva il permesso'). It is interesting to compare the punctuation of the edited and of the translated texts against Scott's transcription of the manuscript, which reads as follows: 'But once fed with my suitcase and our two selves it dashed off like the wind - the door opening and shutting, to his horror, as he is not allowed in the cabs' (KMN2, 9). Where Murry chose to use a comma and Fabietti a semicolon, Mansfield had opted for her signature dash - particularly appropriate to show the 'dash' of the action described.

\footnotetext{
${ }^{14}$ Katherine Mansfield, The Collected Letters of Katherine Mansfield, IV, p. 119.
} 
The overuse of exclamation marks in both the edited and translated texts represents another example of how the author's voice is altered. In her notebooks and fiction, Mansfield used exclamation marks rather moderately. In editing her journal and stories, Murry quite often replaced a full stop or a dash with the exclamation mark. The result is that where Mansfield's text sounds intensely detached, the edited version sounds intensely emotional - even girlish. The Italian translator further emphasized this aspect by adding ad libitum more exclamation marks, as these excerpts demonstrate:

28a

But, my dear, it's such wonderful country all rivers and woods and large birds that look blue in the sunlight. $(J, 24)$

$29 \mathrm{a}$

Oh, I have so much to tell you I'd better not begin. We shall see each other some day, won't we, darling?

$(J, 24)$
$28 \mathrm{~b}$

Oh, mio caro, che paese meraviglioso! Tutto fiumi e boschi e grandi uccelli, che sembrano azzurri nella luce del sole. $(D, 43)$

$29 b$

Oh! Avrei tanto da dirti; è meglio non cominciare neppure. Ci rivedremo pure un giorno o l'altro, non ti pare, mio carissimo? $(D, 43)$

These two passages are drawn from the unposted letter to Frieda Lawrence that Mansfield wrote in Gray in 1915 (see Chapter Two). Frieda's name was replaced by Murry with an anonymous 'dear' (see Chapter Three), which Fabietti translates as 'mio caro'. In English 'dear' can be either masculine or feminine, according to the gender of the person to which it refers. The selection of the masculine gender in the translated text makes it likely that Fabietti interpreted the text as a letter to Mansfield's partner - that is to say, 'J' Murry. This is a reasonable interpretation; after 
all, Fabietti only had Murry's version at her disposal. However, the result of this interpretation is that the words originally written for Frieda Lawrence now sounds like those of a caring spouse:

$30 \mathrm{a}$

But I am so happy I must just send you a word on a spare page of my diary, dear. ( $J$,
$30 \mathrm{~b}$

Ma son tanto felice, che non posso far a meno di mandare a te, mio caro, qualche frase su una pagina disponibile del mio diario. $(D, 42)$

Diario di Katherine Mansfield was included by Corbaccio in the 'Sezione Scarlatta', a series conceived for 'Romanzi d'amore, intimisti e psicologici'. Even this peritextual information reflects the sentimental dominant of the text, based on the image of Mansfield that Murry set out to promote after her death. Some of Fabietti's choices seem to have been influenced by the persuasive and invisible rhetoric of Murry's editing, in a sort of unconscious dialogue between two different textual practices that take place along the continuum of rewriting.

Mara Fabietti produced a version of Mansfield's text that is paradoxically closer to the editor's intentions than to the author's. In this double process of rewriting much of the originary material is lost; meaning is watered down or displaced, as a result of a number of deforming tendencies. To be aware of these tendencies and of how they proliferate - not only within a single text but also from one text to the other - is the first step towards an alternative approach to translation and rewriting. To support my 
argument, I will now read Mansfield's story 'Life of Ma Parker'15 and discuss the way in which I re-translated it into Italian. In moving towards the conclusion of this study, the reading and the translation of this story offers the possibility of returning, one last time, to some rhetorical and ethical issues that the present work has sought to address.

\section{Unshed Tears: Katherine Mansfield's 'Life of Ma Parker'16}

Katherine Mansfield's 'Life of Ma Parker' was published in 1921, one year after Freud's Beyond the Pleasure Principle, and can legitimately be read as a story about death, grief and traumatic awakening to life. ${ }^{17}$

Ma Parker is an old charwoman who has just lost her little grandchild. The day after his funeral, a Tuesday morning, she has already returned to work. Her employer is a 'literary gentleman' - one of Mansfield's satirical portraits of London's 'well-todo pseudo-bohemians'. ${ }^{18}$ The only words of condolence he is able to offer are: 'I hope the funeral was a - a - success' $(C F 2,292)$. The place looks like a 'gigantic dustbin', but this is the gentleman's 'system': 'you simply dirt everything you've got,

${ }^{15}$ Katherine Mansfield, 'Life of Ma Parker', in The Collected Fiction of Katherine Mansfield, Vol. 2, pp. 292-297.

${ }^{16}$ A version of this section will be published as 'Unshed Tears: Meaning, Trauma and Translation', in Katherine Mansfield Studies, ed. by Claire Davidson, Gerri Kimber and W. Todd Martin, Vol. 7 (Edinburgh: Edinburgh University Press, forthcoming 2015).

17 There is no evidence, to my knowledge, that Mansfield had ever read or was familiar with Beyond the Pleasure Principle, which was translated into English only in 1922. It is a well-known fact, however, that many writers of the time were deeply concerned with trauma, and in particular with the traumatic experience of the War. In Mrs Dalloway (1925), for example, through the character of Septimus Warren Smith, Virginia Woolf explored the theme of the 'deferred effects of shell shock' (Mrs Dalloway, London: Penguin, 1992, p. 201).

${ }^{18}$ Sydney Janet Kaplan, Katherine Mansfield and the Origins of Modernist Fiction (Ithaca and London: Cornell University Press, 1991), p. 12. 
get a hag in once a week to clean up, and the thing's done' $(C F 2,293)$. Ma Parker is overwhelmed by grief; while she tidies things up, her mind wanders, revisiting upsetting memories. She has toiled away her whole life: first as a kitchen maid in dreadful places and then as a mother of thirteen children. Seven of these have died; the others have fallen "victim to the other ills of the late-Victorian underclass: emigration, prostitution, poor health, worse luck'. ${ }^{19}$ Ma Parker's husband, a baker, has also died, of tuberculosis, and now her grandchild Lennie - 'all she's got from life' $(C F 2,296)$ - is gone too. In despair, Ma Parker eventually leaves the gentleman's apartment: 'She was like a person so dazed by the horror of what has happened that he walks away - anywhere, as though by walking away he could escape' $(C F 2,296)$. She is determined to find a place where she can 'keep herself to herself' and have 'a proper cry' $(C F 2,297)$. But the ending of the story is unredemptive: in the midst of human indifference, frozen by an icy wind, Ma Parker's tears remain unshed.

An almost compulsive thematic and stylistic repetition marks the story from beginning to end. Repetition is first suggested by the controlled reoccurrence of Ma Parker's activities. Expressions like 'every Tuesday', ‘for years', ‘now and again', 'Many a time' and 'Every Sunday morning' communicate Ma Parker's daily routine. Repetition has settled her pain into habitual gestures; an extraordinary endurance has blended into the banality of an ordinary 'hard life':

\footnotetext{
${ }^{19}$ Susan Lohafer, Reading for Storyness: Preclosure Theory, Empirical Poetics, and Culture in the Short Story (Baltimore: Johns Hopkins University Press, 2003), p. 72.
} 
Then she tied her apron and sat down to take off her boots. To take off her boots or to put them on was an agony to her, but it had been an agony for years. In fact, she was so accustomed to the pain that her face was drawn and screwed up ready for the twinge before she'd so much as untied the laces. (CF2, 292)

'[...] I've had a hard life.'

Even the neighbours said that of her. Many a time, hobbling home with her fish bag she heard them, waiting at the corner, or leaning over the area railings, say among themselves, 'She's had a hard life, has Ma Parker.' And it was so true she wasn't in the least proud of it. It was just as if you were to say she lived in the basement-back at Number 27. A hard life! (CF2, 293)

Nonetheless, as the story unfolds, the way in which Ma Parker recollects her past becomes less predictable, more complex and problematic. A general sense of numbing emerges in Ma Parker's recollection. Her memory is disrupted, fragmented; it is full of gaps - like the fishnet bag she carries; it is a worn memory - like the "very worn' clouds she sees out of a smudgy window. Take, for example, the following two passages:

Nothing remained of Stratford except that 'sitting in the fireplace of a evening you could see the stars through the chimley,' and 'Mother always 'ad 'er side of bacon 'anging from the ceiling.' And there was something a bush, there was - at the front door, that smelt ever so nice. But the bush was very vague. She'd only remembered it once or twice in the hospital, when she'd been taken bad. (CF2, 294)

Her husband sat up in bed with his shirt pulled over his head, and the doctor's finger drew a circle on his back.

'Now, if we were to cut him open here, Mrs Parker,' said the doctor, 'you'd find his lungs chock-a-block with white powder. Breathe, my good 
fellow!' And Mrs Parker never knew for certain whether she saw or whether she fancied she saw a great fan of white dust come out of her poor dear husband's lips... (CF2, 294)

Ma Parker's intrusive thoughts are compulsive attempts at 'translating' the jagged fragments of her past into a cohesive and meaningful narrative. Significantly, the climax of the story coincides with the most painful memory of her recent past, a memory that is not only unbearable but also impossible to understand:

She took her brushes and cloths into the bedroom. But when she began to make the bed, soothing, tucking, patting, the thought of Lennie was unbearable. Why did he have to suffer so? That's what she couldn't understand. Why should a little angel child have to arsk [sic] for his breath and fight for it? There was no sense in making a child suffer like that. (CF2, 296)

The problem of the reference - Lennie's illness and death - becomes here a problem of representation. The pain of Ma Parker, who has survived the death of her grandchild, is unspeakable. And the last touching scene of the story, with Ma Parker failing at having her 'cry out', amplifies the inexpressible dimension of her traumatic grief. Ma Parker's unshed tears are not an answer; they are, however, a repetition: her inability to get rid of her burden of grief repeats, I would argue, Lennie's inability to get rid of the 'great lump of something' in his chest:

From Lennie's little box of a chest there came a sound as though something was boiling. There was a great lump of something bubbling in his chest that he couldn't get rid of. $(C F 2,296)$ 
Ma Parker's impossible cry is a 'symptom of history', ${ }^{20}$ the symptom of a history she cannot entirely possess but only unwittingly repeat, a history that continues to escape her but to which she nonetheless bears witness. ${ }^{21}$

But the problem of reference and representation is also the problem of the author writing the story. It is interesting to note how central is repetition to Mansfield's narrative strategy. Repetition occurs in the use of the flashbacks that punctuate the story; more subtly, it is manifest in the choice of a third-person narrator whose vision and voice largely reflect - repeat - those of the protagonist, as in this passage:

But the struggle she'd had to bring up those six little children and keep herself to herself. Terrible it had been! Then, just when they were old enough to go to school her husband's sister came to stop with them to help things along, and she hadn't been there more than two months when she fell down a flight of steps and hurt her spine. And for five years $\mathrm{Ma}$ Parker had another baby - and such a one for crying! - to look after. Then young Maudie went wrong and took her sister Alice with her; the two boys emigrimated [sic], and young Jim went to India with the army, and Ethel, the youngest, married a good for nothing little waiter who died of ulcers the year little Lennie was born. And now little Lennie - my grandson... (CF2, 296-7)

In this excerpt, through the technique of internal monologue, the narrator approximates the point of view to that of Ma Parker, adopts the character's idiolect, and finally intrudes into her first person ('my grandson'). The narrator reflects Ma

\footnotetext{
${ }^{20}$ Cathy Caruth, Unclaimed Experience, p. 5.

${ }^{21}$ It is worth noting that the 'bubbling' and 'boiling' sound of Lennie's chest repeats, in turn, Mansfield's own experience as a consumptive patient. In a 1920 journal entry, she wrote: 'I cough and cough and at each breath a dragging boiling bubbling sound is heard. I feel that my whole chest is boiling' (KMN2, p. 219).
} 
Parker's stream of consciousness, whose rhetoric rests on repetition. Key words, phrases and certain syntactic structures appear again and again in the text. Polysyndeton - the repetition of the conjunction 'and' - is one such pattern (as is the case in the passage quoted above). Another recurring conjunction is 'but', especially at the beginning of the sentence. ${ }^{22}$ Both 'and' and 'but' refer back to the preceding clauses and, at the same time, move forward to the following ones: they exemplify the 'fort/da' movement of Ma Parker's mind, the traumatic rhetoric of her inner thoughts, her obsessive and frustrated search for meaningful coherence.

Mansfield, as C.K. Stead notes, 'doesn't describe in abstract - she presents'. In her stories, 'rather than being related the events occur' ${ }^{23}$ This preference for showing over telling is particularly suitable to a story where the main character does not simply remember what she has witnessed but also repeats what she has not fully understood. Indeed, the distinction between telling and showing reveals similarities with the distinction between remembering and repeating - a distinction made, as we recall, by Freud in 'Remembering, Repeating and Working Through': 'the patient does not remember anything of what he has forgotten or repressed, but acts it out. He reproduces it not as a memory but as an action; he repeats it without, of course,

\footnotetext{
${ }^{22}$ Consider these examples: 'But Ma Parker bore him no grudge' (293); 'But she'd never heard his name' (294); 'But the bush was very vague' (294); 'But the struggle she'd had to bring up those six little children' (294); 'But it was no use' (295); 'But he was gran's boy from the first' (295); 'But when she began to make the bed' (296); 'But what was more awful' (296); 'But at last' (296); 'But now!' (296); 'But at the thought of crying' (297); 'But to have a proper cry' (297); 'But where?' (297).

${ }^{23}$ C.K. Stead, Kin of Place: Essays on 20 New Zealand Writers (Auckland: Auckland University Press, 2002), p. 20.
} 
knowing that he is repeating it'. ${ }^{24}$ This 'poetics of repetition' has also guided my translation of Mansfield's story.

\section{Translating Mansfield}

One of the main challenges I had to overcome was how to translate Ma Parker's idiolect. Ma Parker's speech is indeed decidedly marked; her accent is transcribed on the page by means of unconventional spelling: 'Beg parding, sir', 'kitching maid', 'to arsk', 'beedles', 'chimley', etc. One option would have been to reformulate Ma Parker's level of discourse using one of the many regional varieties, or even dialects, of the Italian language. Such a decision, however, would have given the text an unjustified overtone of mockery. According to Berman, 'a vernacular clings tightly to its soil and completely resists any direct translating into another vernacular. [...] An exoticization that turns the foreign from abroad into the foreign at home winds up merely ridiculing the original'. ${ }^{25}$ I have compensated for this loss by choosing an almost standard Italian peppered with colloquialism: la mia bella razione ('my share', CF2, 293); non ci vedeva un briciolo di orgoglio ('she wasn't in the least proud of it', CF2, 292); perché se no si perdeva via ('because they made her dreamy', 294); a dirla tutta ('you might say', CF2, 294); e mica una da ridere! ('and such a one for crying!', CF2, 295); Jim era partito soldato in India ('Jim went to India with the army', CF2, 295); non era mai stato un ercolino ('He'd never been a strong child', CF2, 295).

\footnotetext{
${ }^{24}$ Sigmund Freud, 'Remembering, Repeating and Working-Through', p. 150 (Italic in the text).

${ }^{25}$ Antoine Berman, 'Translation and the Trials of the Foreign', p. 286.
} 
Another way to compensate for the losses on the micro-level of single words can be seen in the treatment of syntax. Here is my translation of a passage quoted earlier:

Then, just when they were old enough to go to school her husband's sister came to stop with them to help things along, and she hadn't been there more than two months when she fell down a flight of steps and hurt her spine. And for five years $\mathrm{Ma}$ Parker had another baby - and such a one for crying! - to look after. Then young Maudie went wrong and took her sister Alice with her; the two boys emigrimated $[s i c]$, and young Jim went to India with the army, and Ethel, the youngest, married a good for nothing little waiter who died of ulcers the year little Lennie was born. And now little Lennie - my grandson... (CF2, 295, my emphasis)
Poi, quando erano grandi abbastanza per andare a scuola, la sorella del marito era venuta a stare con loro per darle manforte, $\mathbf{e}$ dopo neanche due mesi non era caduta da una scala rovinandosi la spina dorsale? $\mathrm{E}$ per cinque anni Ma' Parker dovette badare a un'altra figlia - e mica una da ridere! Poi la giovane Maudie si era messa su una cattiva strada, trascinando con sé sua sorella Alice; i due maschi erano migrati e Jim era partito soldato in India e Ethel, la più piccola, aveva sposato quella frana di cameriere, morto di ulcera l'anno in cui era nato Lennie. E adesso lui - il mio nipotino...

This passage reflects, lexically and syntactically, the oral modulation of Ma Parker's internal monologue. Challenging the conventions of standard Italian, I have retained Mansfield's use of polysyndeton without rationalizing the text. Also, I have turned an affirmative sentence ('she fell down a flight of steps and hurt her spine') into a negative rhetorical question (non era caduta da una scala rovinandosi la spina dorsale?), which has the effect of adding emphasis to the assertion, accentuating Ma Parker's point of view and the detours of her perplexed state of mind. In other passages I have made use of marked syntactic structures - in particular dislocations - 
very frequent in spoken Italian: Lo compativa, il povero signorino ('She pitied the poor young gentleman', CF2, 293), Certo che è stata dura, la vita di Ma' Parker ('She's had a hard life, has Ma Parker', CF2, 293), Non ci stavo poi molto in negozio, io ('I wasn't in the shop above a great deal', CF2, 294); Non c'era verso di farlo crescere, il piccolo Lennie (Nothing made little Lennie put it on', CF2, 295); Nient'altro che offeso, pareva ('Only he looked offended', CF2, 296); Si sarebbe spaventata a morte, Ethel ('It would frighten Ethel out of her life', CF2, 297). I would suggest that, in addition to compensating for lexical losses and emphasize the oral level of discourse, dislocation also mimics the 'deferred syntax' of Ma Parker's psyche.

Now let us turn to the translation of 'A hard life!', one of Ma Parker's mental refrains. Rather than translating it with 'Una vita dura!', I have opted for the marked expression 'Dura, la vita!'. Once more, this emphatic construction makes up for the oral, fragmented modulation of Ma Parker's discourse. When I re-read this passage, I noticed, with surprise, that the translation had also gained something on a deeper semantic level. In Italian, 'dura' can be either an adjective ('hard') or a verb (the third person singular of the present tense of durare: 'to last', 'to continue'); thus the expression 'Dura, la vita' means both 'Hard life' and 'Life lasts/continues'. The Italian translation, in my opinion, succeeds in bearing witness to the traumatic truth of $\mathrm{Ma}$ Parker's life: hers is not only a hard life, but a life that, in spite of everything, dura; a life that survives trial, tribulation and trauma without fully understanding their meaning.

Take this other example: 'From Lennie's little box of a chest there came a sound 
as though something was boiling' $(C F 2,296)$. One problem here was the translation of that 'little box of a chest'. What came to mind at first was 'piccola cassa toracica' ('rib cage'), which somehow replicates the metaphor of 'little box'. However, whereas Mansfield's text is tenderly poignant - the point of view is still Ma Parker's - the Italian version would have sounded coldly anatomical. An alternative was to get rid of the metaphor: 'il piccolo petto di Lennie' or 'il petto mingherlino di Lennie'. I discussed this passage with Franca Cavagnoli - an experienced and award-winning literary translator who has translated Mansfield herself - and she suggested modifying 'cassa' with 'cassettina'. The addition of the diminutive suffix makes the Italian version less clinical and more apt to convey Ma Parker's emotional focalization.

Another translational difficulty was to match the sound and rhythm of Mansfield's prose. Italian translations are likely to be between 10 to 15 per cent longer than their English originals. This happens not simply because Italian tends to be more 'wordy' than English, but also because Italian words are often longer than their English counterparts. This has an obvious impact on rhythm. The large number and stunning effect of one-syllable words in English is a constant challenge for the Italian translator. The heavy-handed rendering of a simple modifier, for example, can slacken or annihilate the rhythmic pattern of a sentence. Consider this example: 'That over, she sat back with a sigh and softly rubbed her knees' (CF2, 292). An acceptable translation could be: 'Quand'ebbe finito, si allungò sulla sedia con un sospiro e prese a massaggiarsi delicatamente le ginocchia'. Even a non-native speaker of Italian can hear that the rhythm of the phrase is considerably weighed down. In order to lighten 
it, I sought a verb that could embed the particular semantic nuance indicated by the modifier. I found it in the verb 'soffregare', which alone denotes a soft massage: 'Quand'ebbe finito, si allungò sulla sedia con un sospiro e prese a soffregarsi le ginocchia...' This allowed me to do away with a rather heavy modifier and bring the Italian reader closer to the rhythmic effect of the original; furthermore - and again, unexpectedly - the sound of softly 'survives' in the prefix of the Italian verb 'soffregare'.

Mansfield chooses words for their meaning but also for their sonorous richness or iconic physicality. The translator ought to be aware of this, in order to prevent the 'qualitative impoverishment' of the text - we have noted how Fabietti contributed to the watering down of these features - and the loss of its 'phonetic-signifying truth'. ${ }^{26}$ The description of the sound of Lennie's chest, conveyed through Ma Parker's perspective, is a case in point: 'the great lump bubbled as potato knocks in a saucepan' (CF2, 296). The difficulty was to translate 'knocks'. I could have translated it as: 'il grosso grumo gorgogliava come una patata che bolle [to boil] in pentola', but I would have lost the precise dull sound of the English 'knocks'. This was my final version: 'il grosso grumo gorgogliava con il tic toc di una patata in pentola'. The onomatopoeia allowed me to retain an echo of the source text; and notice the alliteration in 'il grosso grumo gorgogliava', which helped me to reproduce the plosive, drumming sound of 'great lump bubbled'.

\footnotetext{
${ }^{26}$ Antoine Berman, 'Translation and the Trials of the Foreign', p. 283.
} 
The beautiful opening of the last section of the story offers another interesting case: 'It was cold in the street. There was a wind like ice. People went flitting by, very fast; the men walked like scissors; the women trod like cats' $(C F 2,296)$. The challenge here was to reproduce the intense, iconic and sonorous richness of Mansfield's words. My first try was: 'Faceva freddo in strada. Il vento era di ghiaccio. La gente le volteggiava accanto, spedita; gli uomini camminavano come forbici; le donne avanzavano come gatti'. But the translation of 'walk like scissors' and 'trod like cats' with the polysyllables 'camminavano come forbici' and 'avanzavano come gatti' left me unsatisfied; it was a slack rendering of the original. I repeated Mansfield's words aloud again and again, compulsively, until one day two Italian verbs came to my lips that seemed to me to have the iconic and sonorous quality of the original: 'gli uomini sforbiciavano via; le donne sgattaiolavano'. The verb sforbiciare ('to cut with scissors') combined with the adverb via ('away') can be used metaphorically to denote a brisk walk; sgattaiolare refers to the agile, sneaking movement of a cat ('gatto' in Italian). I replaced Mansfield's similes ('walked like scissors'; 'trod like cats') with two metaphorical verbs; however, a metaphor can be seen as 'a shorter simile' (brevior similitudo, in the words of the Roman rhetorician Quintilian), and the use of one word instead of three seems to me to compensate for the lack of one-syllable equivalents. Moreover, the alliteration of spedita, sforbiciavano and sgattaiolavano echoes some of the sounds of the original (in particular the 's' in 'faST', 'ScissoRS', and 'caTS') - a reverberation that the Italian text would have otherwise lost. 
In June 1938 Sigmund Freud took refuge in London from Nazi-occupied Vienna. In a letter to his son Ernst, written shortly before his departure, Freud declared: 'Two prospects keep me going in these grim times: to rejoin you all and - to die in freedom'. Unlike the rest of the letter, the phrase 'to die in freedom' is not written in German but in English. The announcement of Freud's freedom and death, Caruth observes, 'is given in a language that can be heard by those in the new place to which he brings his voice, to us, upon whom the legacy of psychoanalysis is bestowed'. ${ }^{27}$ This is perhaps the kind of witnessing that translation may offer; a form of testimony whose meaning is tied up with the past and at the same time stretches into the future of survival.

\footnotetext{
${ }^{27}$ Cathy Caruth, Unclaimed Experience, p. 23.
} 


\section{Life of Ma Parker - Vita di Ma' Parker}

When the literary gentleman, whose flat old Ma Parker cleaned every Tuesday, opened the door to her that morning, he asked after her grandson. Ma Parker stood on the doormat inside the dark little hall, and she stretched out her hand to help her gentleman shut the door before she replied. 'We buried 'im yesterday, sir,' she said quietly.

'Oh, dear me! I'm sorry to hear that,' said the literary gentleman in a shocked tone. $\mathrm{He}$ was in the middle of his breakfast. $\mathrm{He}$ wore a very shabby dressing-gown and carried a crumpled newspaper in one hand. But he felt awkward. He could hardly go back to the warm sitting-room without saying something - something more. Then because these people set such store by funerals he said kindly, 'I hope the funeral went off all right.'

'Beg parding, sir?' said old Ma Parker huskily.

Poor old bird! She did look dashed. 'I hope the funeral was a - a - success,' said he. Ma Parker gave no answer. She bent her head and hobbled off to the kitchen, clasping the old fish bag that held her cleaning things and an apron and a pair of felt shoes. The literary gentleman raised his eyebrows and went back to his breakfast.

'Overcome, I suppose,' he said aloud, helping himself to the marmalade.

Ma Parker drew the two jetty spears out of her toque and hung it behind the door. She unhooked her worn jacket and hung
Quel mattino, nell'aprire la porta del suo appartamento alla vecchia Ma' Parker, che veniva come ogni martedì a fare le pulizie, il signor letterato le chiese del nipote. $\mathrm{Ma}$ Parker si fermò sullo zerbino nella penombra del piccolo ingresso e, prima di rispondere, allungò una mano per aiutare il padrone di casa a chiudere la porta. 'L'abbiamo sepolto ieri, signore,' disse con calma.

'Oh cielo! Mi dispiace,' disse il letterato profondamente scosso. Era nel bel mezzo della prima colazione. Portava una vestaglia lisa e teneva in mano un giornale sgualcito. Ma non sapeva cosa fare. Ritirarsi nel calduccio del salotto senza dir nulla null'altro - sembrava impossibile. E siccome certa gente attribuiva un'importanza estrema ai funerali, disse gentile: 'Spero che il funerale sia andato bene.'

'Come, signore?' disse la vecchia $\mathrm{Ma}$ Parker con voce roca.

Poveraccia! Sembrava davvero distrutta. 'Spero che il funerale sia stato un... successo,' disse. Ma' Parker non rispose. Si trascinò in cucina a capo chino, stringendo la vecchia sporta di rete in cui teneva l'occorrente per le pulizie e un grembiule e un paio di pantofole di feltro. Il signor letterato alzò le sopracciglia e tornò alla sua colazione.

'Devastata, immagino,' disse a voce alta, prendendo un po' di marmellata di arance.

Ma' Parker sfilò due spilloni neri dalla toque e l'appese dietro la porta. Si sbottonò la giacca logora e appese anche quella. Poi si 
that up too. Then she tied her apron and sat down to take off her boots. To take off her boots or to put them on was an agony to her, but it had been an agony for years. In fact, she was so accustomed to the pain that her face was drawn and screwed up ready for the twinge before she'd so much as untied the laces. That over, she sat back with a sigh and softly rubbed her knees....

'Gran! Gran!' Her little grandson stood on her lap in his button boots. He'd just come in from playing in the street.

'Look what a state you've made your gran's skirt into - you wicked boy!'

But he put his arms round her neck and rubbed his cheek against hers.

'Gran, gi' us a penny!' he coaxed.

'Be off with you; Gran ain't got no pennies.'

'Yes, you 'ave.'

'No, I ain't.'

'Yes, you 'ave. Gi' us one!'

Already she was feeling for the old, squashed, black leather purse.

'Well, what'll you give your gran?'

He gave a shy little laugh and pressed closer. She felt his eyelid quivering against her cheek. 'I ain't got nothing,' he murmured....

The old woman sprang up, seized the iron kettle off the gas stove and took it over to the sink. The noise of the water drumming in the kettle deadened her pain, it seemed. She filled the pail, too, and the washing-up bowl. mise il grembiule e sedette per togliersi gli stivaletti. Toglierseli o infilarseli era per lei una vera tortura, ma una tortura antica. Infatti, era così avvezza al dolore che la faccia le si contrasse in una smorfia ancor prima di sciogliere i lacci - in anticipo sull'ennesima stilettata. Quand'ebbe finito, si allungò sulla sedia con un sospiro e prese a soffregarsi le ginocchia...

'Nonna! Nonna!' Il nipotino le montò in grembo; ai piedi aveva un paio di stivaletti con i bottoni. Era stato fuori a giocare.

'Guarda come hai conciato la gonna della nonna... monello!'

Ma lui le gettò le braccia al collo e strofinò una guancia contro la sua.

'Nonna, dammi una monetina!' disse civettuolo.

'Oh, via! La nonna non ce le ha, le monetine.'

'Sì che ce le hai.'

'No che non ce le ho.'

'Una sola!'

Ed eccola che già partiva alla ricerca del suo vecchio e malconcio borsellino di pelle nera.

'E te cosa dài alla nonna?'

Si sciolse in una risatina timida e la strinse più forte. Sentiva, Ma' Parker, la palpebra di lui tremarle contro la guancia. 'Ma non ho niente, io,' le rispose a fior di labbra.

La vecchia scattò in piedi, afferrò il bollitore di ferro sulla stufa a gas e lo portò al lavandino. Il rumore dell'acqua che tamburellava nel bollitore sembrava smorzarle la pena. Riempì anche un secchio e la vaschetta dei piatti da lavare. 
It would take a whole book to describe the state of that kitchen. During the week the literary gentleman 'did' for himself. That is to say, he emptied the tea leaves now and again into a jam jar set aside for that purpose, and if he ran out of clean forks he wiped over one or two on the roller towel. Otherwise, as he explained to his friends, his 'system' was quite simple, and he couldn't understand why people made all this fuss about housekeeping.

'You simply dirty everything you've got, get a hag in once a week to clean up, and the thing's done.'

The result looked like a gigantic dustbin. Even the floor was littered with toast crusts, envelopes, cigarette ends. But Ma Parker bore him no grudge. She pitied the poor young gentleman for having no one to look after him. Out of the smudgy little window you could see an immense expanse of sadlooking sky, and whenever there were clouds they looked very worn, old clouds, frayed at the edges, with holes in them, or dark stains like tea.

While the water was heating, Ma Parker began sweeping the floor. 'Yes,' she thought, as the broom knocked, 'what with one thing and another I've had my share. I've had a hard life.'

Even the neighbours said that of her. Many a time, hobbling home with her fish bag she heard them, waiting at the corner, or leaning over the area railings, say among themselves, 'She's had a hard life, has Ma Parker.' And it was so true she wasn't in the least proud ofit. It was just as if you were to
Un libro intero ci sarebbe voluto per descrivere lo stato di quella cucina. Durante la settimana il signor letterato 'si arrangiava' da solo. Nel senso che a volte trasferiva le foglie del tè nel vasetto di vetro che teneva appositamente da parte e se rimaneva a corto di forchette pulite ne passava una o due nell'asciugamano a rullo. Per il resto, come spiegava agli amici, il suo 'sistema' era elementare, e non riusciva a capire perché la gente scalpitasse tanto per le faccende domestiche.

'E semplice: imbratti tutto quel che hai, ti prendi una vecchia carampana per una bella ripulita settimanale, e il gioco è fatto.'

Il risultato faceva pensare a una pattumiera gigantesca. Persino il pavimento era cosparso di croste di pane, buste, mozziconi di sigarette. E tuttavia Ma' Parker non gliene voleva. Lo compativa, quel povero signorino, perché non c'era nessuno a prendersi cura di lui. Di là dalla finestrella impiastricciata si vedeva un immenso tratto di cielo dall'aspetto triste, e le poche nuvole all'orizzonte parevano quanto mai logore nuvole vecchie, dagli orli sfilacciati, piene di buchi o di macchie scure color tè.

In attesa che l'acqua si scaldasse, Ma' Parker cominciò a spazzare. 'Sì,' pensava, sbattendo la scopa sul pavimento, 'tra una cosa e l'altra ho avuto anch'io la mia bella razione... Ho avuto una vita dura.'

Lo dicevano anche i vicini. Più di una volta, trascinandosi verso casa con la sua sporta di rete, li aveva sentiti parlare fra loro, fermi all'angolo o appoggiati alla ringhiera. 'Certo che è stata dura, la vita di Ma' Parker,' dicevano. Ed era così vero che lei non ci vedeva un briciolo di orgoglio. Era un po' 
say she lived in the basement-back at Number 27. A hard life! ...

At sixteen she'd left Stratford and come up to London as kitchingmaid. Yes, she was born in Stratford-on-Avon. Shakespeare, sir? No, people were always arsking her about him. But she'd never heard his name until she saw it on the theatres.

Nothing remained of Stratford except that 'sitting in the fire-place of a evening you could see the stars through the chimley,' and 'Mother always 'ad 'er side of bacon 'anging from the ceiling.' And there was something - a bush, there was - at the front door, that smelt ever so nice. But the bush was very vague. She'd only remembered it once or twice in the hospital, when she'd been taken bad.

That was a dreadful place - her first place. She was never allowed out. She never went upstairs except for prayers morning and evening. It was a fair cellar. And the cook was a cruel woman. She used to snatch away her letters from home before she'd read them, and throw them in the range because they made her dreamy. . . . And the beedles! Would you believe it? until she came to London she'd never seen a black beedle. Here Ma always gave a little laugh, as though - not to have seen a black beedle! Well! It was as if to say you'd never seen your own feet.

When that family was sold up she went as 'help' to a doctor's house, and after two years there, on the run from morning till night, she married her husband. He was a baker.

'A baker, Mrs Parker!' the literary gentleman would say. For occasionally he laid aside his tomes and lent an ear, at least, come dire che abitava nel seminterrato sul retro del numero 27. Dura, la vita!

A sedici anni aveva lasciato Stratford ed era venuta a Londra a fare la sguattera. Sì, era di Stratford-on-Avon. Shakespeare, signore? No, le domandavano sempre di lui, ma quel nome non le diceva niente - fino a quando non lo trovò stampato sui teatri.

Nulla restava di Stratford, salvo che 'di sera riuscivi a vedere le stelle da dentro il camino' e 'la mamma teneva sempre il bacon appeso al soffitto'. E davanti alla porta c'era qualcosa... un cespuglio, c'era... che profumava di un buono... Ma del cespuglio aveva un ricordo vago. Le era tornato in mente solo un paio di volte in ospedale, quando era stata male.

Che postaccio - il suo primo posto di lavoro. Uscire era vietato. Poteva salire al piano di sopra solo per le preghiere del mattino e della sera. Uno scantinato in piena regola. E la cuoca era una donna cattiva. Le strappava di mano le lettere da casa prima che avesse finito di leggerle e le buttava nella stufa perché se no si perdeva via... E gli scarafaggi! Possibile? Prima di venire a Londra non ne aveva mai visto uno. Qui Ma' Parker fece una risatina - non aver mai visto uno scarafaggio nero! Ecco, era come dire che non ti eri mai vista i piedi.

Quando quella famiglia chiuse baracca, finì a casa di un dottore come 'servetta', e dopo due anni passati lì a sgobbare dalla mattina alla sera, prese marito. Faceva il fornaio.

'Un fornaio, Mrs Parker!' diceva il signor letterato. Perché talvolta metteva giù i suoi tomi e prestava orecchio, se non altro, a quel 
to this product called Life. 'It must be rather nice to be married to a baker!'

Mrs Parker didn't look so sure.

'Such a clean trade,' said the gentleman.

Mrs Parker didn't look convinced.

'And didn't you like handing the new loaves to the customers?'

'Well, sir,' said Mrs Parker, 'I wasn't in the shop above a great deal. We had thirteen little ones and buried seven of them. If it wasn't the 'ospital it was the infirmary, you might say!

'You might, indeed, Mrs Parker!' said the gentleman, shuddering, and taking up his pen again.

Yes, seven had gone, and while the six were still small her husband was taken ill with consumption. It was flour on the lungs, the doctor told her at the time. . . . Her husband sat up in bed with his shirt pulled over his head, and the doctor's finger drew a circle on his back.

'Now, if we were to cut him open here, Mrs Parker,' said the doctor, 'you'd find his lungs chock-a-block with white powder. Breathe, my good fellow!' And Mrs Parker never knew for certain whether she saw or whether she fancied she saw a great fan of white dust come out of her poor dear husband's lips ...

But the struggle she'd had to bring up those six little children and keep herself to herself. Terrible it had been! Then, just when they were old enough to go to school her husband's sister came to stop with them to help things along, and she hadn't been there more than two months when she fell down a flight of steps and hurt her spine. And for five years Ma Parker had another baby - and such a one for crying! - to look prodotto chiamato Vita. 'Non dev'essere niente male essere sposati a un fornaio!'

Mrs Parker non sembrava tanto sicura.

'Un'attività così pulita...' disse il letterato.

Mrs Parker non sembrava convinta.

'E non le piaceva porgere le pagnotte fresche ai clienti?'

'Mah, signore,' disse Mrs Parker, 'non ci stavo poi molto in negozio, io. Ne avevamo tredici da tirar su e ne abbiamo sepolti sette. Se non era l'ospedale era l'infermeria, a dirla tutta!'

'A dirla tutta tutta, Mrs Parker!' disse il letterato, rabbrividendo, e riprendendo la penna in mano.

Sì, sette se n'erano andati, e mentre gli altri sei erano ancora piccoli, il marito si ammalò di tisi. C'era della farina nei polmoni, le disse il dottore quella volta... Il marito si tirò su nel letto con la camicia sollevata e il dito del dottore tracciò un cerchio sulla schiena.

'Ebbene, se dovessimo fare un taglio qui, Mrs Parker,' disse il dottore, 'troverebbe i polmoni pieni zeppi di polvere bianca. Faccia un bel respiro, amico mio!' E Mrs Parker era ancora lì a chiedersi se quel gran ventaglio di polvere bianca che si aprì dalle labbra di suo marito buonanima l'avesse visto davvero o solo immaginato...

Ma quanto aveva penato, e senza darlo a vedere, per crescere quei sei bambini. Terribile, a pensarci! Poi, quando erano grandi abbastanza per andare a scuola, la sorella del marito era venuta a stare con loro per darle manforte, e dopo neanche due mesi non era caduta da una scala rovinandosi la spina dorsale? E per cinque anni Ma' Parker dovette badare a un'altra figlia - e mica una da ridere! Poi la giovane 
after. Then young Maudie went wrong and took her sister Alice with her; the two boys emigrimated, and young Jim went to India with the army, and Ethel, the youngest, married a goodfor-nothing little waiter who died of ulcers the year little Lennie was born. And now little Lennie - my grandson....

The piles of dirty cups, dirty dishes, were washed and dried. The ink-black knives were cleaned with a piece of potato and finished off with a piece of cork. The table was scrubbed, and the dresser and the sink that had sardine tails swimming in it....

He'd never been a strong child - never from the first. He'd been one of those fair babies that everybody took for a girl. Silvery fair curls he had, blue eyes, and a little freckle like a diamond on one side of his nose. The trouble she and Ethel had had to rear that child! The things out of the newspapers they tried him with! Every Sunday morning Ethel would read aloud while Ma Parker did her washing.

'Dear Sir, - Just a line to let you know my little Myrtil was laid out for dead. ... After four bottils ... gained 8 lbs. in 9 weeks, and is still putting it on.'

And then the egg-cup of ink would come off the dresser and the letter would be written, and Ma would buy a postal order on her way to work next morning. But it was no use. Nothing made little Lennie put
Maudie si era messa su una cattiva strada, trascinando con sé sua sorella Alice; i due maschi erano migrati e Jim era partito soldato in India e Ethel, la più piccola, aveva sposato quella frana di cameriere, morto di ulcera l'anno in cui era nato Lennie. E adesso lui - il mio nipotino...

Aveva ormai rigovernato la pila di tazze e piatti sporchi. I coltelli neri come l'inchiostro erano stati ripuliti con un pezzo di patata e lucidati con uno di sughero. Il tavolo ben strofinato, così come la credenza e il lavandino in cui nuotavano code di sardine...

No, non era mai stato un ercolino - fin dall'inizio. Appena nato, era uno di quei maschietti che tutti prendono per una femminuccia. Riccioli di un biondo argenteo, occhi azzurri, e una lentiggine, come una puntina di diamante, su un lato del naso. Quel che non avevano fatto lei e Ethel per tirar su quel bambino! Tutti quei rimedi sui giornali che gli avevano propinato! Ogni domenica, mentre $\mathrm{Ma}^{\prime}$ Parker lavava i panni, Ethel leggeva a voce alta.

Gentile Signore, solo due righe per informarLa che il mio piccolo Myrtil, che era stato dato per morto ... dopo quattro flaconcini di ... ha messo su quasi quattro chili in nove settimane, $e$ continua $a$ prendere peso...

E allora tiravano giù dalla credenza il portauovo con dentro l'inchiostro e scrivevano la lettera e l'indomani Ma' Parker, andando al lavoro, si sarebbe fermata in posta a compilare un vaglia. $\mathrm{Ma}$ 
it on. Taking him to the cemetery, even, never gave him a colour; a nice shake-up in the bus never improved his appetite.

But he was gran's boy from the first. ...

'Whose boy are you?' said old Ma Parker, straightening up from the stove and going over to the smudgy window. And a little voice, so warm, so close, it half stifled her - it seemed to be in her breast under her heart - laughed out, and said, 'I'm gran's boy!'

At that moment there was a sound of steps, and the literary gentleman appeared, dressed for walking.

'Oh, Mrs Parker, I'm going out.'

'Very good, sir.'

'And you'll find your half-crown in the tray of the inkstand.'

'Thank you, sir.'

'Oh, by the way, Mrs Parker,' said the literary gentleman quickly, 'you didn't throw away any cocoa last time you were here - did you?'

'No, sir.'

'Very strange. I could have sworn I left a teaspoonful of cocoa in the tin.' He broke off. He said softly and firmly, 'You'll always tell me when you throw things away won't you, Mrs Parker?' And he walked off very well pleased with himself, convinced, in fact, he'd shown Mrs Parker that under his apparent carelessness he was as vigilant as a woman.

The door banged. She took her brushes and cloths into the bedroom. But when she began to make the bed, smoothing, tucking, era tutto inutile. Non c'era verso di farlo crescere, il piccolo Lennie. Nemmeno un giro al camposanto gli fece prendere colore; i sobbalzi dell'autobus non servirono ad aumentargli l'appetito.

Ma lui era il bello di nonna - fin dall'inizio...

'Cosa sei tu?' diceva la vecchia $\mathrm{Ma}$ Parker mettendo in ordine, spostandosi dalla stufa alla finestrella impiastricciata. E una vocina, così calda, così intima, che a momenti la soffocava... pareva avercela in petto, sotto il cuore... scoppiava a ridere e diceva: 'Sono il bello di nonna!'

In quel momento si udirono dei passi e il signor letterato si affacciò, in vestito da passeggio.

'Oh, Mrs Parker, sto uscendo.'

'Molto bene, signore.'

'E troverà la sua mezza corona nel vassoio del calamaio.'

'Grazie, signore.'

'A proposito, Mrs Parker,' incalzò il signor letterato, 'ha mica buttato via del cacao l'ultima volta che è stata qui?'

'No, signore.'

'Molto strano. Avrei giurato di averne lasciato giusto un cucchiaino nel barattolo.' Tacque. Pacato e perentorio disse: 'Lei non butta via niente a mia insaputa... vero, Mrs Parker?' E se ne andò tutto compiaciuto, convinto, in effetti, di aver appena mostrato a Mrs Parker che dietro la sua apparente noncuranza c'era lo spirito vigile di una donna.

La porta sbatté. Lei portò spazzole e stracci in camera. Ma quando cominciò a rifare il letto, a forza di lisciare, rimboccare e 
patting, the thought of little Lennie was unbearable. Why did he have to suffer so? That's what she couldn't understand. Why should a little angel child have to arsk for his breath and fight for it? There was no sense in making a child suffer like that.

. . From Lennie's little box of a chest there came a sound as though something was boiling. There was a great lump of something bubbling in his chest that he couldn't get rid of. When he coughed the sweat sprang out on his head; his eyes bulged, his hands waved, and the great lump bubbled as a potato knocks in a saucepan. But what was more awful than all was when he didn't cough he sat against the pillow and never spoke or answered, or even made as if he heard. Only he looked offended.

'It's not your poor old gran's doing it, my lovey,' said old Ma Parker, patting back the damp hair from his little scarlet ears. But Lennie moved his head and edged away. Dreadfully offended with her he looked - and solemn. He bent his head and looked at her sideways as though he couldn't have believed it of his gran.

But at the last ... Ma Parker threw the counterpane over the bed. No, she simply couldn't think about it. It was too much she'd had too much in her life to bear. She'd borne it up till now, she'd kept herself to herself, and never once had she been seen to cry. Never by a living soul. Not even her own children had seen Ma break down. She'd kept a proud face always. But now! Lennie gone - what had she? She had nothing. He was all she'd got from life, and now he was took too. Why must it all have carezzare, il pensiero del piccolo Lennie si fece insostenibile. Perché ha dovuto soffrire così È questo che non riusciva a capire. Perché un angioletto di creatura doveva limosinare ogni respiro, conquistarselo a così caro prezzo? Non aveva alcun senso far tribolare un bimbo in quel modo...

La cassettina toracica di Lennie mandava il suono di qualcosa in ebollizione. C'era una specie di grosso grumo che gli gorgogliava dentro e di cui non riusciva a liberarsi. Quando tossiva il sudore gli irrorava la fronte; spalancava gli occhi, agitava le mani e il grosso grumo gorgogliava con il tic toc di una patata in pentola. Ma ancora più terribile era quando non tossiva, quando stava lì appoggiato al cuscino senza parlare o rispondere o dar segno di aver udito. Nient'altro che offeso, pareva.

'Non è colpa della nonna, amore mio,' diceva Ma' Parker, aggiustandogli i capelli sudati dietro le piccole orecchie scarlatte. Ma Lennie muoveva la testa e si tirava in là. Terribilmente offeso con lei, pareva - e solenne. Piegava la testa e la guardava di sbieco, come a dire che no, dalla sua nonna non se lo sarebbe mai aspettato.

$\mathrm{E}$ alla fine... Ma' Parker tirò su il copriletto. No, non riusciva nemmeno a pensarci. Era davvero troppo - aveva sopportato fin troppo nella vita. Aveva sopportato tutto fino adesso, senza darlo a vedere, e nessuno l'aveva mai vista piangere. Non un'anima. Nemmeno i suoi figli l'avevano vista crollare. Aveva mantenuto uno sguardo fiero - sempre. Ma adesso!? Morto Lennie, cosa le restava? Non le restava niente. Lui era tutto ciò che aveva avuto dalla vita e adesso gliel'avevano 
happened to me? she wondered. 'What have I done?' said old Ma Parker. 'What have I done?'

As she said those words she suddenly let fall her brush. She found herself in the kitchen. Her misery was so terrible that she pinned on her hat, put on her jacket and walked out of the flat like a person in a dream. She did not know what she was doing. She was like a person so dazed by the horror of what has happened that he walks away - anywhere, as though by walking away he could escape....

It was cold in the street. There was a wind like ice. People went flitting by, very fast; the men walked like scissors; the women trod like cats. And nobody knew - nobody cared. Even if she broke down, if at last, after all these years, she were to cry, she'd find herself in the lock-up as like as not.

But at the thought of crying it was as though little Lennie leapt in his gran's arms. Ah, that's what she wants to do, my dove. Gran wants to cry. If she could only cry now, cry for a long time, over everything, beginning with her first place and the cruel cook, going on to the doctor's, and then the seven little ones, death of her husband, the children's leaving her, and all the years of misery that led up to Lennie. But to have a proper cry over all these things would take a long time. All the same, the time for it had come. She must do it. She couldn't put it off any longer; she couldn't wait any more. . . Where could she go?

'She's had a hard life, has Ma Parker.' portato via. Anche lui. Perché è successo tutto a me? si domandava. 'Che ho fatto?' diceva la vecchia Ma' Parker. 'Ma che ho fatto?'

A quelle parole, inaspettatamente, lasciò cadere la spazzola. Si ritrovò in cucina. La sua infelicità era così totale che si rimise il cappello, la giacca e uscì dall'appartamento come in un sogno. Cosa stesse facendo non lo sapeva. Era come chi, scosso da un evento orribile, se ne allontana - senza una direzione precisa, pensando di poter sfuggire...

Faceva freddo in strada. Il vento era di ghiaccio. La gente le volteggiava accanto, spedita. Gli uomini sforbiciavano via; le donne sgattaiolavano. E nessuno sapeva - a nessuno importava. Anche se fosse crollata... se alla fine, dopo tutti quegli anni, fosse scoppiata in lacrime... di sicuro l'avrebbero rinchiusa da qualche parte.

Ma al solo pensiero di piangere, ecco il piccolo Lennie saltarle in braccio di nuovo. $\mathrm{Ah}$, stella mia, è questo che vuole fare. La nonna vuole piangere. Se solo riuscisse a piangere ora, e a lungo, versare lacrime su tutto, cominciando dal suo primo impiego e la cuoca cattiva, e poi dal dottore, e i sette figlioletti, e la morte del marito, e i figli che prendono e se ne vanno, e tutti quegli anni di miseria su su fino a Lennie. Ma chissà quanto tempo ci sarebbe voluto per piangere come si deve. Fa lo stesso, il momento era arrivato. Doveva decidersi. Non avrebbe potuto rimandarlo ancora; non poteva più aspettare... Dove poteva andare?

'Certo che è stata dura, la vita di Ma' 
Yes, a hard life, indeed! Her chin began to tremble; there was no time to lose. But where? Where?

She couldn't go home; Ethel was there. It would frighten Ethel out of her life. She couldn't sit on a bench anywhere; people would come arsking her questions. She couldn't possibly go back to the gentleman's flat; she had no right to cry in strangers' houses. If she sat on some steps a policeman would speak to her.

$\mathrm{Oh}$, wasn't there anywhere where she could hide and keep herself to herself and stay as long as she liked, not disturbing anybody, and nobody worrying her? Wasn't there anywhere in the world where she could have her cry out - at last?

Ma Parker stood, looking up and down. The icy wind blew out her apron into a balloon. And now it began to rain. There was nowhere.
Parker.' Dura, la vita, dura! Il mento iniziò a tremarle; non c'era tempo da perdere. Ma dove? Dove?

Non poteva andare a casa; lì c'era Ethel. Si sarebbe spaventata a morte, Ethel. Non poteva sedersi su una panchina qualsiasi; la gente avrebbe chiesto spiegazioni. Figurati se poteva tornare a casa del letterato; mica aveva il diritto di piangere nelle case degli altri. Se si fosse fermata su un gradino un poliziotto sarebbe venuto a interrogarla.

$\mathrm{Oh}$, non c'era dunque un posto dove appartarsi, senza darlo a vedere, e rimanerci finché le fosse piaciuto, senza disturbare nessuno e senza nessuno che la tormentasse? Ma non c'era un posto al mondo dove piangere tutte le sue lacrime - finalmente?

Ma' Parker si fermò, guardò avanti e indietro. Il vento gelido le gonfiò il grembiule come un pallone. E adesso cominciava a piovere. No, non c'era nessun posto. 


\section{Conclusions}

Tchehov made a mistake in thinking that if he had had more time he would have written more fully [...]. The truth is one can get only so much into a story; there is always a sacrifice. One has to leave out what one knows and longs to use. Why? I haven't any idea, but there it is. It's always a kind of race to get in as much as one can before it disappears.

KATHERINE MANSFIELD

The study of Katherine Mansfield's literary reuse of her notebook material, combined with John Middleton Murry's 1927 edition of the Journal of Katherine Mansfield, Mara Fabietti's Italian translation of it and my own version of Mansfield's 'Life of Ma Parker', has brought to light how different textual practices can be read together along the continuum of the rewriting process.

I have described and analysed this process using an interdisciplinary approach that includes literary, textual, translation and trauma studies.

Rewriting, I have argued, always implies a rhetorical and ethical tension between the display and the displacement of meaning - a tension that is exemplified by Mansfield's short stories. I have suggested that Murry's editorial method as well as Fabietti's translational strategies and solutions can be read in narrative terms. The editor's textual manipulation displayed a purified and sentimentalized version of Mansfield. The Italian translator took this process even further, empoverishing the 
specificities of source text by adopting a number of 'deforming tendencies' such as clarification, expansion and ennoblement. Fabietti 'repeated' the rhetoric driving Murry's editing, just like Murry had repeated, in his editing, the sense of fragmentation and the desire for completion that painfully permeates Mansfield's writing. My translation of 'Life of Ma Parker' offers another - and different - example of the echoing nature of rewriting. Laboring upon the text's letter, according to Berman's translation ethics, I have endeavoured to repeat Mansfield's narrative strategy and the peculiar modulations of Ma Parker's voice.

Trauma theory has served as analytical framework in my description of rewriting. The repetition compulsion through which the traumatized attempts at working out his or her neuroses shares similarities with the compulsion to repeat enacted in the process of rewriting - which can be defined as the ever-frustrated attempt to understand a meaning that is not yet fully grasped.

The practice of translation - itself a form of testimony that implies a certain degree of loss - exemplifies this process. If, on the one hand, rewriting is the impossible task of representing what is, by nature, unrepresentable, on the other hand, it offers the potential for an 'afterlife'. With Caruth, 'Repetition is not simply the attempt to grasp what has almost died but, more fundamentally, and enigmatically, the very attempt to claim one's own survival'. ${ }^{1}$

\footnotetext{
${ }^{1}$ Cathy Caruth, Unclaimed Experience, p. 64.
} 
One of the challenges and ambitions of this thesis was to adopt a broad interdisciplinary perspective and, at the same time, to narrow down the theme of rewriting to what I consider some of its central theoretical problems. This approach resulted, inevitably, in the exclusion of some related discussions that certainly deserve further consideration.

The theme of Mansfield as a rewriter, for example, should now hold a prominent place in Mansfield scholarship, which is still dominated by the romantic view of the author as a spontaneous writer, ignited by the flame of inspiration. The ways in which Mansfield reused her notebook material (as discussed in Chapter 2) could be expanded by way of analysis of other stories. Also, an investigation of her compositional method should take into account Mansfield's controversial reuse of the work of other writers - Wilde and Chekhov in particular - as the forthcoming collection of essays Katherine Mansfield and Literary Influence aims to show. ${ }^{2}$ Finally, a closer attention needs to be paid to the writer's own editorial and translation practice. While the theme of Mansfield and translation has been taken up recently, ${ }^{3}$ the editorship of her own fiction (such as the complex revision process that led from the 1915 'The Aloe' to the 1917 'Prelude', to name just one example) calls for more sustained scholarly scrutiny.

2 Katherine Mansfield and Literary Influence, ed. by Sarah Ailwood and Melinda Harvey (Edinburgh: Edinburgh University Press, forthcoming 2015).

${ }^{3}$ See Claire Davidson, Translation as Collaboration: Virginia Woolf, Katherine Mansfield and S. Koteliansky (Edinburgh: Edinburgh University Press, 2014). 
Another interesting theme that I have not addressed in this study is Mansfield's reception in Italy and the impact of her work on Italian writers - in particular women. ${ }^{4}$ One may inquire, for example, to what extent the reception of the author in Italy has been filtered through Mara Fabietti's translation of the Journal. The possibility of Mansfield's influence on 1920s and 1930s Italian literature - especially on the so-called 'prosa d'arte' - as well as on subsequent writers, critics and intellectuals is also significant. The case of Elsa Morante (1912-1985), who translated the Scrapbook of Katherine Mansfield (1939) into Italian, is particularly interesting. ${ }^{5}$ Mansfield had some effect on Morante's writing: her 1941 short-story 'Un uomo senza carattere', for instance, clearly echoes Mansfield's 1920 'A Man Without a Temperament', and Diario 1938, published posthumously in 1989, reveals a number of stylistic and thematic connections with the Journal. ${ }^{6}$ These reflections lead to further venues of study that lie outside the scope of this thesis, but that hopefully my research will help to put into focus.

If my theoretical analysis of rewriting has concentrated primarily on some aspects of trauma theory, this is because I believe that Trauma and Memory Studies provide,

4 An outdated but still useful introduction to this topic is offered by J.B. Ringer in "II Mansfieldismo": A Survey of Mansfield Criticism in Italy', Landfall, 36 (June 1982). See also Maurizio Ascari, 'An "utterly concrete and yet impalpable” Art: The Early Reception of Katherine Mansfield in Italy (1922-1952)', in Katherine Mansfield and Continental Europe: Connections and Influences, ed. by. G. Kimber and J. Kascakova (Basingstoke: Palgrave McMillan, 2015), pp. 7-25.

${ }^{5}$ Katherine Mansfield, Il libro degli appunti, trans. Elsa Morante (Milano-Roma: Rizzoli 1945). See also Nicoletta Di Ciolla, 'Elsa Morante, translator of Katherine Mansfield', in Under Arturo's Star: The Cultural Legacies of Elsa Morante, ed. by Stefania Lucamente and Sharon Wood (West Lafayette: Purdue University Press, 2005), pp. 45-66.

${ }^{6}$ Elsa Morante, 'Un uomo senza carattere', in Opere, Vol. 1 (Milano: Meridiani Mondadori 1988), pp. 1501-1508); Diario 1938 (Torino: Einaudi, 1998). 
with Translation Studies, the most original contribution to some pressing philosophical and ethical issues revolving around the notion of rewriting. In addition to Freud and Caruth, one could also include other important figures working in the same stream (I think, in particular, of Dominick LaCapra, Kali Tal, Shoshana Felman and Janine Altounian). It is not by chance that Memory and Translation Studies occupy an assured and unique position in the contemporary literary debate: the questions that memory and translation ask return with increasing urgency today, demanding intellectual recognition, empathetic response and ethical engagement. 


\section{Works Cited}

Agamben, Giorgio, State of Exception, trans. by Kevin Attell (London: The University of Chicago Press, 2005)

Ailwood, Sarah, and Melinda Harvey, Katherine Mansfield and Literary Influence (Edinburgh: Edinburgh University Press, forthcoming 2015)

Alpers, Anthony, The Life of Katherine Mansfield (Oxford: Oxford University Press, 1982)

Asimakoulas, Dimitris, 'Rewriting', in Routledge Encyclopedia of Translation Studies, ed. by Mona Baker and Gabriela Saldanha, $2^{\text {nd }}$ ed. (New York: Routledge, 2009)

Barenghi, Mario, L'autorità dell'autore (Milano: Unicopli, 2000)

Bassnett, Susan, 'Prologue', in Tradition, Translation, Trauma: The Classic and the Modern, ed. by Jan Parker and Timothy Mathews (Oxford: Oxford University Press, 2011) 
Bassnett, Susan, 'The Translation Turn in Cultural Studies', in Constructing Culture: Essays on Literary Translation, ed. by Susan Bassnett and André Lefevere (Clevedon: Multilingual Matters)

Bassnett, Susan, Translation Studies (New York: Routledge, 2002)

Benjamin, Walter, 'The Storyteller', in Illuminations: Essays and Reflections, trans. by Harry Zohn (New York: Schochen Books, 1969)

Benjamin, Walter, 'The Task of the Translator: An Introduction to the Translation of Baudelaire's Tableaux Parisiens', The Translation Studies Reader, ed. by Lawrence Venuti, trans. by Harry Zohn (New York: Routledge, 2004)

Bennett, Andrew, Katherine Mansfield (Devon: Northcote House, 2004)

Bennett, Andrew, The Author (New York: Routledge, 2005)

Berman, Antoine, 'Translation and the Trials of the Foreign', in Venuti, ed., The Translation Studies Reader, trans. by Lawrence Venuti (New York: Routledge, 2004)

Boase-Beier, Jean and Michael Holman, eds, The Practice of Literary Translation: Constraints and Creativity, ed. by (Manchester: St. Jerome Publishing, 1998)

Boddy, Gillian, 'Leaving “All Fair”? Working Towards a New Edition of Katherine Mansfield's Notebooks', in Worlds of Katherine Mansfield, ed. by Harry Ricketts (Palmerston North: Nagarre Press, 1991)

Booth, Wayne C., The Rhetoric of Fiction (Chicago: The University of Chicago Press, 1983) 
Brooks, Cleanth, 'My Credo: The Formalist Critics', Kenyon Review, XIII (1951)

Brooks, Peter, Reading For the Plot: Design and Intention in Literature (Cambridge, Ma: Harvard University Press, 1992)

Caruth, Cathy, Literature in the Ashes of History (Baltimore: The Johns Hopkins University Press, 2013)

Caruth, Cathy, ed., Trauma: Explorations in Memory (Baltimore: The Johns Hopkins University Press, 1995)

Caruth, Cathy, Unclaimed Experience: Trauma, Narrative and History (Baltimore and London: Johns Hopkins University Press, 1996)

Darrohn, Christine, 'Blown to Bits!: Katherine Mansfield's “The Garden Party” and the Great War', Modern Fiction Studies, 44: 3 (1998)

Davidson, Claire, Translation as Collaboration: Virginia Woolf, Katherine Mansfield and S. Koteliansky (Edinburgh: Edinburgh University Press, 2014)

Derrida, Jacques, 'Des tours des Babel', in Difference and Translation, ed. by Joseph F. Graham (Ithaca: Cornell University Press, 1985)

Even-Zohar, Itamar, 'The Position of Translated Literature Within the Literary Polysystem', in Literature and Translation, ed. by James Holmes, Jose Lambert and Raymond van den Broek (Leuven: ACCO, 1978)

Flaubert, Gustave, The Letters of Gustave Flaubert, 1830-1857, ed. by Francis Steegmuller (Cambridge, Mass.: Harvard University Press, 1980) 
Freud, Sigmund, 'Remembering, Repeating and Working-Through', in The Standard Edition of Complete Psychological Works of Sigmund Freud, trans. by James Strachey, Vol. 12 (London: Hogarth, 1953-74)

Freud, Sigmund, Beyond the Pleasure Principle, in The Standard Edition of the Complete Psychological Works of Sigmund Freud, Vol. 18 (London: Hogarth, 1953-74)

Genette, Gérard, Palimpsests: Literature in the Second Degree, trans. by Channa Newman and Claude Doubinsky (Lincoln: University of Nebraska Press, 1997)

Gentzler, Edwin, Contemporary Translation Theories (Clevedon, England, Buffalo, N.Y.: Multilingual Matters, 2001)

Gillies, Mary Ann, and Aurelea Mahood, Modernist Literature: An Introduction (Edinburgh: Edinburgh University Press, 2007)

Gordon, Ian, 'Katherine Mansfield in the Late Twentieth Century', in The Fine Instrument, ed. by Paulette Michel and Michel Dupuis (Sydney: Dangaroo Press, 1989)

Gordon, Ian, 'The Editing of Katherine Mansfield's Journal and Scrapbook', Landfall, 13, no. 1, (March 1959)

Grossman, Edith, Why Translation Matters (New Haven: Yale University Press, 2010)

Hanson, Clare, and Andrew Gurr, Katherine Mansfield (London and Basingstoke: The MacMillan Press LTD, 1981) 
Hanson, Clare, The Critical Writings of Katherine Mansfield (Basingstoke, Hampshire: Macmillan, 1987)

Hermans, Theo, The Manipulation of Literature (London: Croom Helm, 1985)

Hermans, Theo, Translation in Systems. Descriptive and System-oriented Approaches Explained (Manchester: St. Jerome, 1999)

Jackson, Anna, Diary Poetics: Form and Style in Writers' Diaries (New York: Routledge, 2010)

Jones, Kathleen, Katherine Mansfield: The Storyteller (London: Penguin, 2010)

Joyce, James, A Portrait of the Artist As a Young Man, ed. by Jeri Johnson (Oxford: Oxford University Press)

Kant, Immanuel, The Critique of Judgement, trans. by James Creed Meredith (Oxford: Clarendon Press, 1952)

Kaplan, Sydney Janet, Circulating Genius: John Middleton Murry, Katherine Mansfield and D.H. Lawrence (Edinburgh: Edinburgh University Press, 2010)

Kaplan, Sydney Janet, Katherine Mansfield and the Origins of Modernist Fiction (Ithaca and London: Cornell University Press, 1991)

Kimber, Gerri, Katherine Mansfield: The View from France (Oxford: Peter Lang, 2008)

Kimber, Gerri, and Janka Kascakova, eds, Katherine Mansfield and Continental Europe: Connections and Influences (Basingstoke: Palgrave McMillan, 2015). 
Lea, F.A., The Life of John Middleton Murry (London: Methuen, 1959)

Leader, Zachary, Revision and Romantic Authorship (Oxford: Oxford University Press, 1996)

Lefevere, André, 'Translated Literature: Towards an Integrated Theory', The Bulletin of the Midwest Modern Language Association, Vol. 14, No. 1 (Spring, 1981)

Lefevere, André, 'Translation Studies: The Goal of the Discipline', in Literature and Translation, ed. by James Holmes, Jose Lambert and Raymond van den Broek (Leuven: ACCO, 1978)

Lefevere, André, Translation, Rewriting and the Manipulation of Literary Fame (London: Routledge, 1992)

Lohafer, Susan, Reading for Storyness: Preclosure Theory, Empirical Poetics, and Culture in the Short Story (Baltimore: Johns Hopkins University Press, 2003)

Lucamente, Stefania, and Sharon Wood, eds, Under Arturo's Star: The Cultural Legacies of Elsa Morante (West Lafayette: Purdue University Press, 2005)

Manenti, Davide, 'Indiscreet Journeys: Rewriting Katherine Mansfield', in Authorial and Editorial Voices in Translation: Editorial and Publishing Practices, ed. by Hanne Hansen and Anna Wegener (Montréal: Les Éditions québécoises de l'œuvre, 2013)

Manenti, Davide, 'From the Store to the Story: Katherine Mansfield and the Question of Rewriting', in Katherine Mansfield Masked and Unmasked (Special Issue), Journal of 
New Zealand Literature, ed. by Charles Ferrall, Anna Jackson, Harry Ricketts, Marco Sonzogni and Peter Whiteford, No. 32: 2 (2014)

Manenti, Davide, 'Unshed Tears: Meaning, Trauma and Translation', in Katherine Mansfield Studies, ed. by Claire Davidson, Gerri Kimber and W. Todd Martin, Vol. 7 (Edinburgh: Edinburgh University Press, forthcoming 2015)

Mansfield, Katherine, Diario (Milano: Corbaccio, 1933)

Mansfield, Katherine, Diario (Roma: Robin Editore, 2002)

Mansfield, Katherine, Il libro degli appunti, trans. Elsa Morante (Milano-Roma: Rizzoli 1945)

Mansfield, Katherine, Letters and Journals of Katherine Mansfield: A Selection, ed. by C.K. Stead (London: Penguin, 1977)

Mansfield, Katherine, Journal of Katherine Mansfield, ed. by John Middleton Murry (London: Constable, 1927)

Mansfield, Katherine, Journal of Katherine Mansfield, ed. by John Middleton Murry (London: Persephone Press, 2006)

Mansfield, Katherine, Journal of Katherine Mansfield, 'Definitive Edition', ed. by John Middleton Murry (London: Constable, 1954)

Mansfield, Katherine, The Aloe, ed. by Vincent O'Sullivan (Wellington: Port Nicholson Press Limited, 1982) 
Mansfield, Katherine, The Collected Fiction of Katherine Mansfield, ed. by Gerri Kimber and Vincent O’Sullivan, 2 vols (Edinburgh: Edinburgh University Press, 2012)

Mansfield, Katherine, The Collected Letters of Katherine Mansfield, ed. by Vincent O’Sullivan and Margaret Scott, 5 vols (Oxford: Oxford University Press, 1984-2008)

Mansfield, Katherine, The Katherine Mansfield Notebooks, ed. by Margaret Scott, 2 vols (Canterbury NZ: Lincoln University Press and Daphne Brasell Associates, 1997)

Mansfield, Katherine, The Urewera Notebook, ed. by Ian Gordon (Oxford: Oxford University Press, 1978)

Mantz, Ruth, 'Katherine Mansfield: Fifty Years After', Adam (1972)

Maupassant, Guy de, 'Le Roman', in Romans, ed. by Albert-Marie Schmidt, (Paris: Éditions Albin Michel, 1970)

McGann, Jerome, A Critique of Modern Textual Criticism (Chicago: University of Chicago, 1983)

McKenzie, D.F., Bibliography and the Sociology of Texts (Cambridge: Cambridge University Press, 1999)

Meyers, Jeffrey, 'Murry’s Cult of Mansfield', Journal of Modern Literature, Vol. 7, No. 1 (1979)

Middleton Murry, John, Discoveries: Essays in Literary Criticism (London: Collins, 1924)

Middleton Murry, John, Selected Criticism, 1916-1957 (Oxford: Oxford University Press, 1960) 
Morante, Elsa, Diario 1938 (Torino: Einaudi, 1989)

Morante, Elsa, Opere, Vol. 1 (Milano: Meridiani Mondadori 1988)

Nathan, Rhoda B., Critical Essays on Katherine Mansfield (New York: G.K. Hall, 1993)

Oates, Joyce Carol, 'The Aesthetic of Fear', in Where I've Been, and Where I'm Going: Essays, Reviews, and Prose (New York: Plume, 1999)

Oliver, Fiona, ‘The 2012 Alexander Turnbull Library Mansfield/Murry Acquisition', in Katherine Mansfield Studies, ed. by Janet Wilson, Gerri Kimber and Delia da Sousa Correa, Vol. 5 (Edinburgh: Edinburgh University Press, 2013)

Ortega y Gasset, José, 'The Misery and the Splendor of Translation', in Theories of Translation: An Anthology of Essays from Dryden to Derrida, ed. by Rainer Schulte and John Biguenet, trans. by Elizabeth Gamble Miller (Chicago: University of Chicago Press, 1992)

Parker, Dorothy, The Portable Dorothy Parker (New York: Viking Press, 1973)

Ricoeur, Paul, On Translation, trans. by Eileen Brennan (New York: Routledge, 2006)

Ringer, J.B., "'Il Mansfieldismo”: A Survey of Mansfield Criticism in Italy', Landfall, 36, (June 1982).

Smith, Angela, Katherine Mansfield and Virginia Woolf: A Public of Two (New York, Oxford: Clarendon Press, 1999)

Snell-Hornby, Mary, The Turns of Translation Studies (Philadelphia, Amsterdam: J. Benjamins Pub, 2006) 
Sontag, Susan, 'The Artist as Exemplary Sufferer', in Against Interpretation and other Essays (London: Penguin, 2009)

Steiner, George, After Babel: Aspects of Language and Translation (Oxford: Oxford University Press, 1992)

Stafford, Jane, and Mark Williams, 'Katherine Mansfield: A Modernist in Maoriland', in Maoriland: New Zealand Literature 1872-1914 (Wellington: Victoria University Press, 2006)

Stead, C.K., Kin of Place: Essays on 20 New Zealand Writers (Auckland: Auckland University Press, 2002)

Stillinger, Jack, Multiple Authorship and the Myth of Solitary Genius (Oxford: Oxford University Press, 1991)

Tomalin, Claire, Katherine Mansfield: A Secret Life (London: Viking, 1987)

Venuti, Lawrence, ed., The Translation Studies Reader (New York: Routledge, 2004)

Venuti, Lawrence, ed., Rethinking Translation: Discourse, Subjectivity, Ideology (London: Routledge, 1992)

Venuti, Lawrence, The Translator's Invisibility: A History of Translation (New York, Routledge, 2008)

Waldron, Philip, 'Katherine Mansfield's Journal', Twentieth Century Literature, 20, No. 1 (January 1974) 
Webby, Elizabeth, 'Katherine Mansfield: Everything and Nothing', in 'Meanjin', 41:2 (1982)

Wevers, Lydia, 'How Kathleen Beauchamp Was Kidnapped', in Critical Essays on Katherine Mansfield, ed. by Rhoda B. Nathan (New York: G.K. Hall, 1993)

Williams, Mark, "'The Artificial and the Natural": The Development of Katherine Mansfield's Prose Style', in Telling Stories: Postcolonial Short Fiction in English, ed. by Jacqueline Bardolph (Amsterdam - Atlanta: Editions Rodopi B.V., 2001)

Woolf, Leonard, The Autobiography of Leonard Woolf(London: Hogarth Press, 1964)

Woolf, Virginia, 'A terribly Sensitive Mind', in The Critical Response to Katherine Mansfield

Woolf, Virginia, Mr. Bennett and Mrs. Brown (London: Hogarth Press, 1924)

Woolf, Virginia, Mrs Dalloway (London: Penguin, 1992)

Woolf, Virginia, The Diary of Virginia Woolf, ed. by Anne Olivier Bell, 5 vols (London: Hogarth Press, 1977-84)

Wordsworth, William, The Oxford Authors: William Wordsworth, ed. Stephen Gill (Oxford: Oxford University Press, 1994) 
Copyright (C) 2015 by Davide Manenti

All rights reserved. 